MAATALOUDEN TALOUDELLISEN TUTKIMUSLAITOKSEN JULKAISUJA N:o 11 PUBLICATIONS OF THE AGRICULTURAL ECONOMICS RESEARCH INSTITUTE, FINLAND, No. 11

\title{
DEMAND AND SUPPLY OF PORK AND BEEF IN FINLAND
}

LAURI KETTUNEN 


\section{DEMAND AND SUPPLY OF PORK AND BEEF IN. FINLAND}

LAURI KETTUNEN

HELSINKI 1968 
Helsinki 1968. Valtion painatuskeskus 


\section{PREFACE}

As this study goes to press, it is my agreeable duty to express my thanks to all those who have cooperated in bringing it about.

First of all I wish to thank Professor Samudj. Suomeda, Head of the Agricultural Economics Research Institute, who provided me with an opportunity to concentrate on this study, virtually free from other duties. To Professor PaAvo KaARLEHTo, Head of the Marketing Research Department of the Institute, I owe a particular debt of graditute for all the discussions I have had with him and for the comments he has made on my study and the corrections he has suggested. His expert knowledge of both agricultural policy and methodological questions have been of utmost value to me throughout my work.

I also wish to thank my teacher, Professor Pent'ti Pöyнönen, for the encouragement he has given for this study. He also read my typescript and suggested many important corrections.

During the inital phase of this study I had an opportunity to receive valuable guidance from Professor B. F. Stanton, Cornell University. The discussions I had with him were particularly valuable in the methodological respect. My sincerest thanks are due to him.

My colleagues at the Agricultural Economics Research Institute, Mr Jorura Kalimo, Mr Lauri Pölkki and Dr Matias ToRveida, have given me help in many forms. Mrs MaRITA Kronholm very painstakingly assisted me in preparing the typescript for press. I wish to express my thanks to all of them.

I also wish to thank Mr JaAkKo RaILo, who checked the English text of my study.

Finally, I acknowledge my debt of gratitute to August Johannes and Aino Tiura Foundation for Agricultural Research, the Finnish Cultural Foundation, the Alma and Jussi Jalkanen Foundation and the University of Helsinki for the grants they have awarded me for this study.

Helsinki, March 1968. 


\section{CONTENTS}

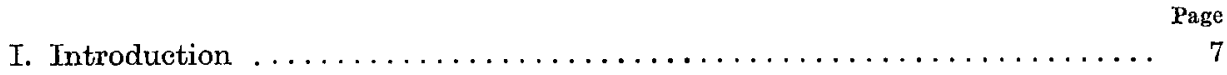

1. The target price system for pork and beef $\ldots \ldots \ldots \ldots \ldots \ldots \ldots \ldots, 7$

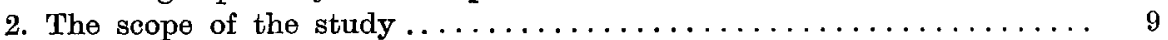

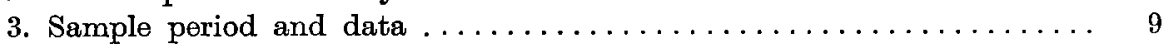

4. Production, consumption and price development $\ldots \ldots \ldots \ldots \ldots \ldots 10$

4.1 Data on quantities and prices of pork $\ldots \ldots \ldots \ldots \ldots \ldots \ldots \ldots$

4.2 Data on quantities and prices of beef $\ldots \ldots \ldots \ldots \ldots \ldots \ldots$ ll

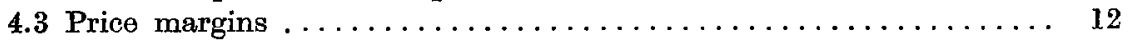

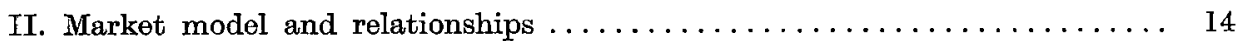

5. The structure of pork and beef markets $\ldots \ldots \ldots \ldots \ldots \ldots \ldots \ldots \ldots$

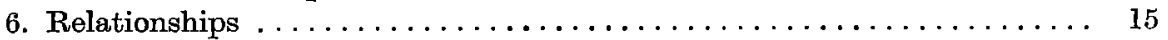

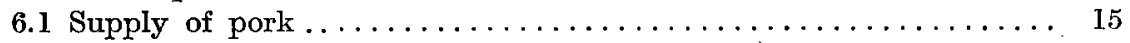

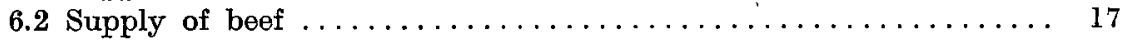

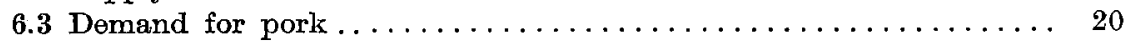

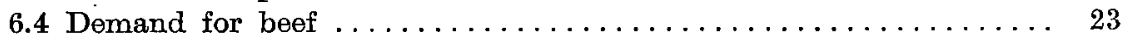

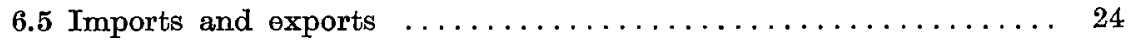

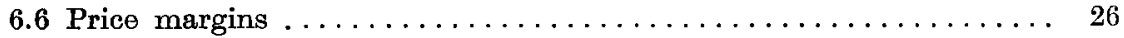

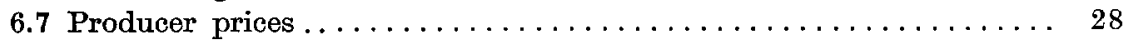

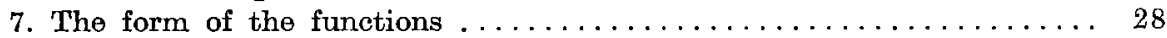

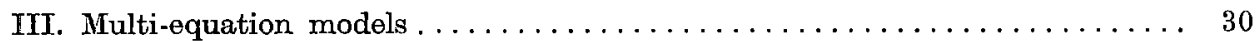

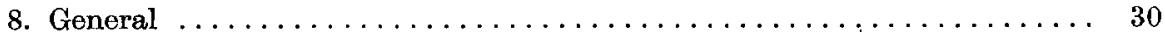

9. The character of the multi-equation models $\ldots \ldots \ldots \ldots \ldots \ldots \ldots \ldots, 32$

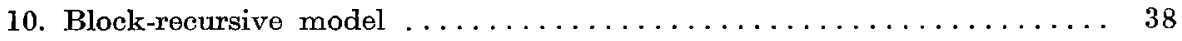

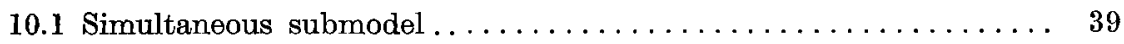

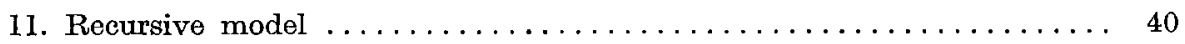

IV. Estimates of the parameters . . . . . . . . . . .

12. Elimination of seasonal variation $\ldots \ldots \ldots \ldots \ldots \ldots \ldots \ldots \ldots \ldots, 44$

13. Different estimates of parameters and statistical tests $\ldots \ldots \ldots \ldots \ldots 45$

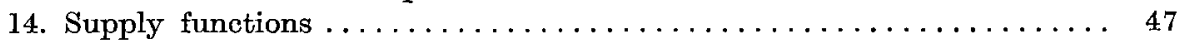

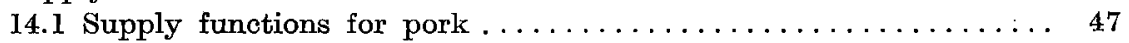

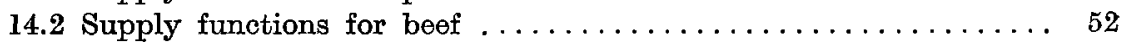

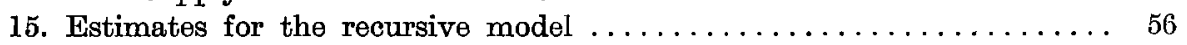

16. Estimates for the block-recursive model ............... 65

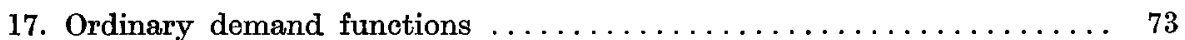

18. Evaluation of the estimated models $\ldots \ldots \ldots \ldots \ldots \ldots \ldots \ldots$

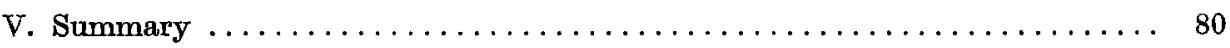

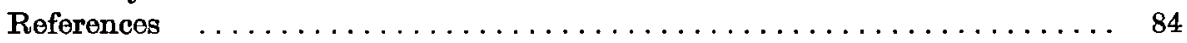

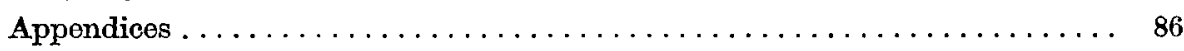




\section{INTRODUCTION}

\section{The target price system for pork and beef}

To provide a background for the present study, a brief description of the target price system for pork and beef is called for. Target prices belong to the main features of the Finnish agricultural price policy. This policy has found expression in several Acts on Agricultural Price Level passed and applied since 1956. It would not be meaningful to try to describe the content of these acts in this connection; we only refer to the article by Suomera. ${ }^{x}$ All these laws have had one common feature: the necessary changes in the price level have had to be effected through fixing so-called target (producer) prices for the basic agricultural products (specified separately in each act). The target price products have accounted for the bulk of the total agricultural output, and thus the prices for them have determined the agricultural price level. Under these acts it has been up to the government to secure the achievement of target prices, by interfering with the formation of producer prices if necessary. The means for that are, in the case of pork and beef, export subsidization and border protection.

Target prices for pork have been set since the crop year 1956/57 and target prices for beef since $1962 / 63$ (the crop year as used in connection with these laws begins on September 1).

The target prices are fixed for a whole crop year at a time, even though they may be changed during the crop year (in February). The average of the actual producer price for a crop year need not, however, be invariably equal to the target price, but it is permitted to deviate from its target price by a percentage specified for each product. In the case of milk, the most important product, the deviation is allowed to be only \pm 1 per cent. The permissible deviation from the target price of pork has been \pm 5 per cent. In the case of beef, for which target prices were not set until the crop year $1962 / 63$, the permissible deviation was at first \pm 10 per cent, and it has been 5 per cent since $1965 / 66$.

1 Suomera, Samuli: The Changing Agricultural Price Laws. Economic Review No. 2, 1967, published by Kansallis-Osake-Pankki, Helsinki, pp. 44-45. 
Target prices are only fixed for entire crop years. Nevertheless, the movements of the producer prices of pork and beef, for example, are followed up on a monthly basis (making due allowance for seasonal variations); and attempts are usually made to keep the producer prices within the target price limits. If the actual producer price for pork or beef deviates from the target price by more than \pm 5 per cent, the government has to take actions to bring the producer price within the specified price range. If the producer price is below the lower limit, subsidies should be paid to export firms to cover the difference between the target price minus 5 per cent and the world market price. If the producer price is above the upper limit, imports should be allowed to such an extent that the producer price will fall within the range.

The attainment of target prices depends ultimately upon whether opportunities exist for exports, i.e., whether export markets are available; or whether imports are possible, which is not always the case, since diseases, for example, may result in a shortage of beef on the world market. Also, a lack of funds for subsidies may prevent exports. Thus, it is obvious that for a succesful price policy, i.e., for setting the target prices that can be achieved, a good knowledge about the supply and the price formation of both products, pork and beef, would be quite helpful. If the quantity supplied could be predicted, we might expect to be able to predict what the producer price will be and set the target prices accordingly; or if the target price is set independently, we might estimate the need for exports or imports, to find the markets in time. Unfortunately, few quantitative studies are available for that purpose. One to be mentioned here is that by KAARLEHTo, an empirical study on the pork market in Finland, based on data from the years 1952-56. ${ }^{1}$ Another is HaIKara's study, a theoretical analysis on the cobweb theorem, of which the pork market is a good example. ${ }^{2}$ Little attention has been paid to beef markets. There are available only some estimates of price elasticities obtained from time series ${ }^{3}$ and of income elasticities obtained from budget studies. 4 The parameters mentioned above have been estimated for a model where only one product is considered, whereas today the best way to estimate the demand and supply elasticities of both commodities is considered to be the use of multi-equation models and estimation methods:

1 KaArlehto, Paavo: Sianlihan markkinoinnista Suomessa (Summary: A Study on the Pork Market in Finland). Maatalouden taloudellisen tutkimuslaitoksen julkaisuja No. 2. Helsinki 1959.

2 Harkala, Eino: Maatalouden ominaissuhdanteet ja Cobweb-teoria (Summary: On the Specific Cycles of Agriculture and the Cobweb Theorem). Helsinki 1956.

3. SANDELIN, Gustav: Naudanlihan kysynnästä (Summary: About demand for beef). PellervoSeuran markkinatutkimuslaitoksen 25-vuotisjulkaisu. Helsinki 1959, pp. 34-38.

4 KaARLEHTO, Paavo: Tulotason vaikutuksesta elintarvikemenoihin ja kulutusmäärïn (Summary: Income Elasticity of Food Expenditure and Consumption). Maataloustieteellinen aikakauskirja, Vol. 33, No. 1, pp. 17-33. 


\section{The scope of the study}

The need for functions suitable for the price policy purposes considered above was an incentive to undertake this study. Limitations in the available data, to be described later on, set, however, restrictions on the estimation of the structure of the pork and beef markets. Therefore, the writer will concentrate on building a model which could later be applied (a) by reestimating the parameters every year, say, since these parameters are very likely to change continuously due to structural changes, and (b) by modifying the model as soon as the necessary additional data are available.

Supply functions will first be constructed for the prediction of the domestic production of both products, and secondly, import and export functions will be derived. These functions determine the total domestic supply of both products. Thirdly, the demand functions will be derived that determine the retail price as a function of the consumption of both products and the disposable income; and fourthly, price margin functions will be derived to explain the difference between the retail and producer prices. As a final step, the producer price will be computed simply by subtracting the price margin from the retail price. These relationships are derived in Chapter II.

The way in which the problem is approached leads to the use of multiequation models. Before selecting the method of estimation, the character of the models, recursive or simultaneous, must be specified. This rather complicated problem and some other difficulties encountered in using different estimation methods are discussed in Chapter III. The estimates yielded by empirical study are given in Chapter IV.

\section{Sample period and data}

The estimation is based on data for 1956 to 1965 . The reason why earlier years were not included was that statistios of the marketed quantities of pork and beef have been published only since 1955. It would seem that the gathering of these statistics has taken place on a sufficiently uniform basis since 1956, and thus the basic data are homogeneous.

Quarterly time series are used for estimation. The basic data available for this study are monthly, except for those on the production for consumption on the farms, which are semiannual. Therefore, the data on total production, consisting of the quantities marketed and the quantities consumed on farms, are semiannual. The computation of the quarterly data on total production is described in Appendix I. Since there may be some errors in the computed data, the semiannual data are also used for estimation.

$2 \quad 8609-68$ 


\section{Production, consumption and price development}

First, the movements in the production, consumption and prices of pork and beef during the sample period will be discussed briefly, in order to characterize the data available for this study. The figures given in this connection will provide an overall picture of the relationships between certain variables of interest.

\subsection{Data on quantities and prices of pork}

The total production of pork consists of two components: the quantities marketed (slaughtered and inspected in the slaughterhouses) and the quantities consumed on farms. These two components have moved in directions opposed to each other, as is seen from Table 4.1, where estimates of annual consumption are derived.

Exports and imports were sufficient to offset the changes in production to a large extend, so that consumption was rather stable during the research period. The range of variation in per capita consumption was only $1.4 \mathrm{~kg}$. In 1966 per capita consumption increased up to $15.5 \mathrm{~kg}$, which might suggest that pork consumption will increase in the future. However, it has not yet reached the pre-World War II level. For example, in 1938 pork consumption was $16.1 \mathrm{~kg}$ per capita. It is possible that, as income rises, pork consumption will reach a saturation point and start to decrease. This has happened, for example, in the U.S.A., where per capita consumption of pork is declining slowly.

The relationship between the retail price of pork and the quantity supplied in the domestic market is seen from Figure 4.1, where the per capita consumption and the retail price of pork, as deflated by the cost of

Table 4.1. Production, imports, exports and consumption of pork in $1956-65$

\begin{tabular}{|c|c|c|c|c|c|c|c|}
\hline \multirow{3}{*}{ Year } & \multicolumn{3}{|c|}{ Production } & \multirow{3}{*}{$\begin{array}{l}\text { Imports } \\
\text { mill. kg }\end{array}$} & \multirow{3}{*}{$\begin{array}{l}\text { Exports } \\
\text { mill. kg }\end{array}$} & \multicolumn{2}{|c|}{ Consumption ${ }^{1}$} \\
\hline & \multirow[b]{2}{*}{$\begin{array}{c}\text { Total } \\
\text { mill. } \mathrm{kg}\end{array}$} & \multicolumn{2}{|c|}{ of which } & & & \multirow[b]{2}{*}{$\begin{array}{c}\text { Total } \\
\text { mill. } \mathrm{kg}\end{array}$} & \multirow[b]{2}{*}{$\begin{array}{l}\mathrm{kg} \text { per } \\
\text { capita }\end{array}$} \\
\hline & & $\begin{array}{c}\text { marketed } \\
\text { mill. kg }\end{array}$ & $\begin{array}{c}\text { consumed } \\
\text { on farms } \\
\text { mill. kg }\end{array}$ & & & & \\
\hline 1956 & 59.0 & 41.1 & 17.9 & 1.56 & - & 60.6 & 14.2 \\
\hline 1957 & 64.3 & 45.8 & 18.5 & - & 0.76 & 63.5 & 14.7 \\
\hline 1958 & 67.3 & 48.7 & 18.6 & - & 1.65 & 65.7 & 15.0 \\
\hline 1959 & 62.1 & 47.0 & 15.1 & 0.01 & 1.17 & 61.0 & 13.8 \\
\hline 1960. & 54.4 & 39.2 & 15.2 & 5.12 & - & 59.5 & 13.4 \\
\hline 1961. & 61.3 & 48.1 & 13.2 & 2.17 & 1.29 & 62.2 & 13.9 \\
\hline 1962. & 67.4 & 55.0 & 12.4 & 0.52 & 1.35 & 66.5 & 14.8 \\
\hline 1963. & 66.7 & 55.2 & 11.5 & 0.93 & 1.73 & 65.9 & 14.5 \\
\hline 1964. & 66.8 & 56.3 & 10.5 & 1.07 & 2.03 & 65.8 & 14.4 \\
\hline 1965 & 68.7 & 58.8 & 9.9 & 1.12 & 2.43 & 67.4 & 14.6 \\
\hline
\end{tabular}

1) Domestic disappearance would be a better term for this column, since changes in storage holdings, waste and spoiling of meat cannot be estimated. 


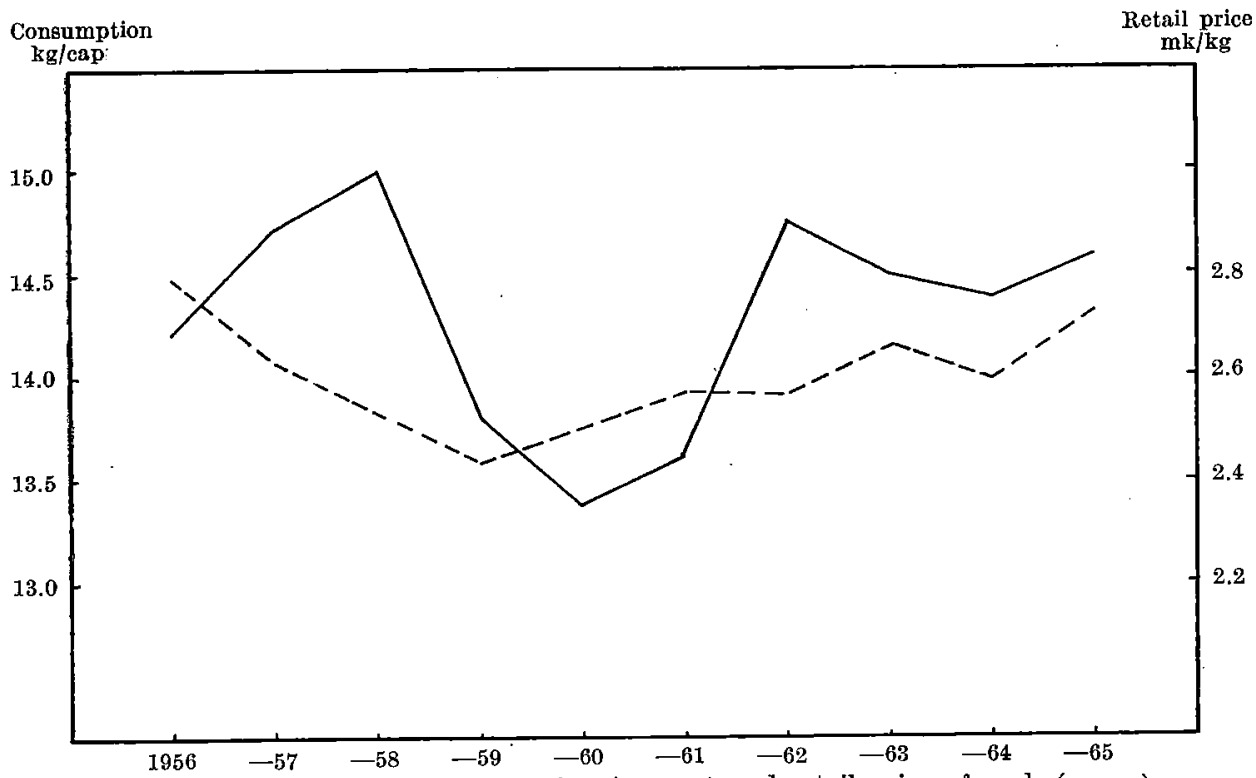

Figure 4.1. The per capita consumption (- - ) and retail price of pork (--- ) , as deflated by the cost of living index, in 1956-65.

living index, are presented. This relationship, i.e., the demand function for pork is one of the main functions to be estimated in this study.

\subsection{Data on quantities and prices of beef}

Production, imports, exports and consumption (domestic disappearance) of beef ${ }^{1}$ are presented in Table 4.2. While pork consumption was rather

Table 4.2. Production, imports, exports and consumption of beef in 1956-65

\begin{tabular}{|c|c|c|c|c|c|c|c|}
\hline \multirow{3}{*}{ Year } & \multicolumn{3}{|c|}{ Production } & \multirow{3}{*}{$\begin{array}{l}\text { Imports } \\
\text { mill. kg }\end{array}$} & \multirow{3}{*}{$\begin{array}{l}\text { Exports } \\
\text { mill. kg }\end{array}$} & \multicolumn{2}{|c|}{ Consumption } \\
\hline & \multirow[b]{2}{*}{$\begin{array}{l}\text { Total } \\
\text { mill. kg }\end{array}$} & \multicolumn{2}{|c|}{ of which } & & & & \\
\hline & & $\begin{array}{l}\text { marketed } \\
\text { mill. } \mathrm{kg}\end{array}$ & $\begin{array}{l}\text { consumed } \\
\text { on farms } \\
\text { mill. kg }\end{array}$ & & & $\begin{array}{l}\text { Lotal } \\
\text { mill. } \mathrm{kg}\end{array}$ & $\begin{array}{l}\text { kg per } \\
\text { capita }\end{array}$ \\
\hline 1956 & 67.6 & 59.7 & 7.9 & - & - & 67.6 & 15.8 \\
\hline $1957 \ldots \ldots$ & 65.1 & 58.2 & 6.9 & - & - & 65.1 & 15.0 \\
\hline $1958 \ldots \ldots \ldots$ & 63.8 & 57.4 & 6.4 & 一 & - & 63.8 & 14.6 \\
\hline $1959 \ldots \ldots \ldots$ & 71.6 & 66.5 & 5.1 & - & - & 71.6 & 16.3 \\
\hline 1960 . & 71.6 & 66.0 & 5.6 & - & 一 & 71.6 & 16.2 \\
\hline 1961 . & 68.3 & 62.8 & 5.5 & 10.0 & - & 78.3 & 17.5 \\
\hline 1962 . & 80.6 & 74.9 & 5.7 & 1.1 & $\ldots$ & 81.7 & 18.2 \\
\hline 1963. & 88.3 & 81.7 & 6.6 & 一 & 0.1 & 88.4 & 19.5 \\
\hline $1964 \ldots \ldots \ldots \ldots$ & 98.0 & 90.5 & 7.5 & $\therefore$ & 0.1 & 97.9 & 21.4 \\
\hline $1965 \ldots \ldots \ldots$ & 94.6 & 88.4 & 6.2 & 0.8 & 1.5 & 94.0 & 20.4 \\
\hline
\end{tabular}

I For convenience, only beef will be spoken about, even though the data employed also includes veal. It was not considered necessary to treat the two separately. 


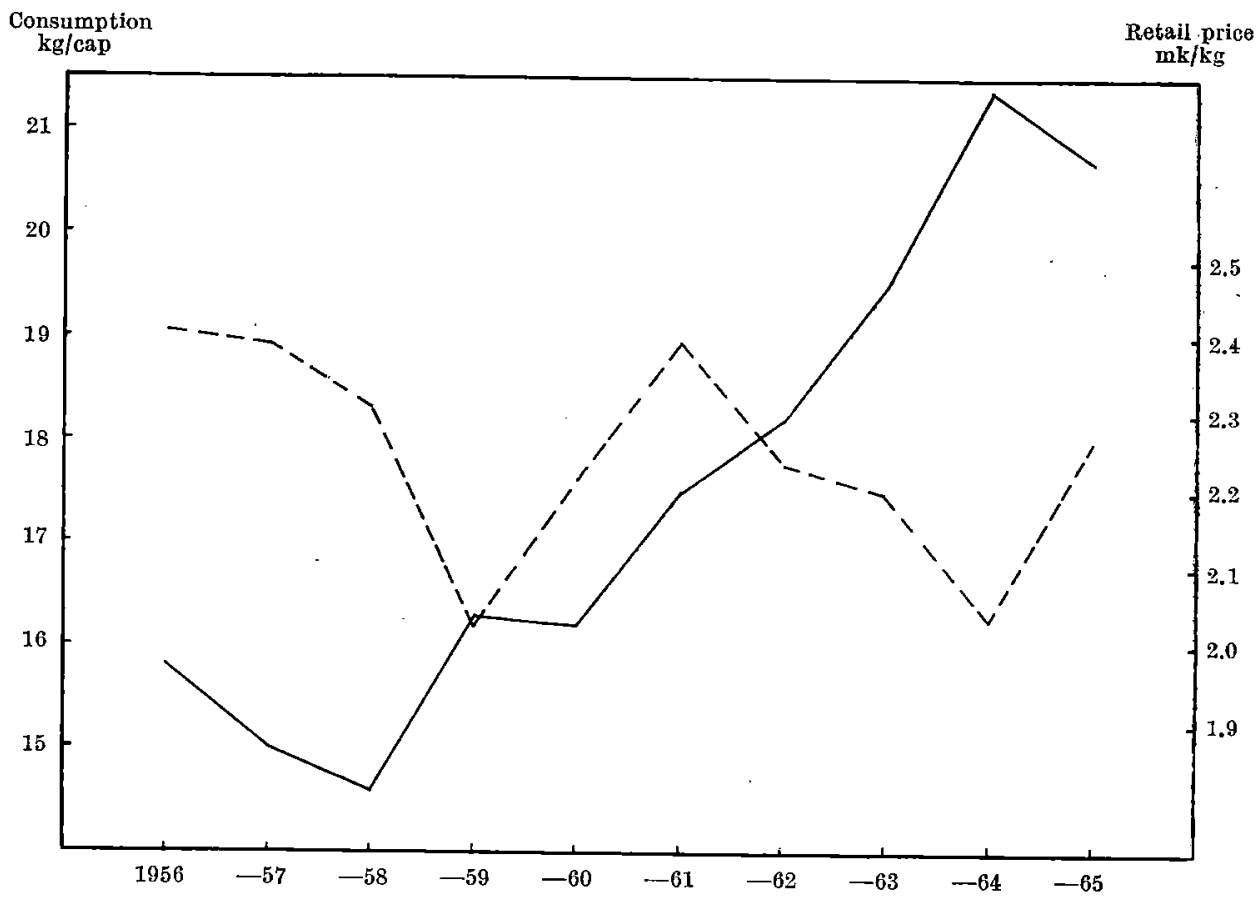

Figure 4.2. The per capita consumption $\left(-\frac{}{2}\right)$ and retail price of beef $(-\ldots)$, as deflated by the cost of living index, in $1956-65$

stable, the consumption of beef increased quite rapidly after 1958. The proportion of the production of beef consumed on farms varied much less than that of pork, and no distinct trend was in evidence. This may facilitate the statistical analysis for beef, since it justifies assuming that the market behavior was stable during the research period. In the case of pork, the marked change in the relationship between production and the quantities marketed may disturb the analysis. Therefore, separate supply analyses will be made of total production and of the quantity marketed.

Due to the trend in consumption, the relationship between retail price as deflated by the cost of living index and per capita consumption (domestic supply) of beef (Figure 4.2) is not as clear as that for pork.

\subsection{Price margins}

The relationship between retail price and producer price is one of the objects of this study. Attention will then be focused on the price margins, i.e., the difference between retail price and producer price. As is shown by Table 4.3, the development of the price margin for pork was rather regular: the absolute margin increased steadily and the percentage ratio of the margin 
Table 4.3. Retail and producer prices and price margins for pork and beef and price margin as a percentage of the retail price in $1956-65$

\begin{tabular}{|c|c|c|c|c|c|c|c|c|}
\hline \multirow[b]{2}{*}{ Year } & \multicolumn{4}{|c|}{ Pork } & \multicolumn{4}{|c|}{ Beef } \\
\hline & $\begin{array}{c}\text { Retail } \\
\text { price } \\
\mathrm{mk} / \mathrm{kg}\end{array}$ & $\begin{array}{c}\text { Producer } \\
\text { price } \\
\mathrm{mk} / \mathrm{kg}\end{array}$ & $\begin{array}{c}\text { Price } \\
\text { margin } \\
\mathrm{mk} / \mathrm{kg}\end{array}$ & $\begin{array}{l}\text { Per- } \\
\text { cen- } \\
\text { tage }\end{array}$ & $\begin{array}{l}\text { Retail } \\
\text { price } \\
\mathrm{mk} / \mathrm{kg}\end{array}$ & $\begin{array}{l}\text { Producer } \\
\text { price } \\
\mathrm{mk} / \mathrm{kg}\end{array}$ & $\begin{array}{c}\text { Price } \\
\text { margin } \\
\mathrm{mk} / \mathrm{kg}\end{array}$ & $\begin{array}{l}\text { Per- } \\
\text { cen- } \\
\text { tage }\end{array}$ \\
\hline 1956 & 3.09 & 2.30 & 0.79 & .25 .6 & 2.67 & 2.05 & 0.62 & 23.2 \\
\hline 1957 & 3.24 & 2.41 & 0.83 & 25.6 & 2.95 & 2.42 & 0.53 & 18.0 \\
\hline 1958 & 3.10 & 2.28 & 0.82 & 26.5 & 3.06 & 2.23 & 0.83 & 27.1 \\
\hline 1959 & 3.27 & 2.44 & 0.83 & 25.4 & 2.72 & 2.05 & 0.67 & 24.6 \\
\hline 1960 & 3.76 & 2.86 & 0.90 & 23.9 & 3.06 & 2.56 & 0.50 & 16.3 \\
\hline 1961 & 3.63 & 2.65 & 0.98 & 27.0 & 3.36 & 2.77 & 0.59 & 17.6 \\
\hline $1962 \ldots$ & 3.77 & 2.70 & 1.07 & 28.4 & 3.28 & 2.67 & 0.61 & 18.6 \\
\hline $1963 \ldots$ & 4.12 & 2.90 & 1.22 & 29.6 & 3.39 & 2.65 & 0.74 & 21.8 \\
\hline $1964 \ldots \ldots \ldots \ldots$ & 4.42 & 3.01 & 1.41 & 31.9 & 3.42 & 2.56 & 0.86 & 25.1 \\
\hline $1965 \ldots \ldots \ldots \ldots$ & 4.85 & 3.34 & 1.51 & 31.1 & 4.03 & 3.15 & 0.88 & 21.8 \\
\hline
\end{tabular}

to the retail price was rather stable, increasing only toward the end of the research period. In the case of beef the picture was less clear-cut. The price margin, both in absolute terms and as a percentage of retail price, varied irregularly during the sample period. 


\section{MARKET MODEL AND RELATIONSHIPS}

\section{The structure of pork and beef markets}

A diagrammatic representation of the variables and relationships crucial to the construction of pork and beef economy models is given in Figure 5.1. Because the number of factors which determine the quantity of pork or beef supplied is large, they are not all included here, but are discussed later, when the supply functions are constructed. Consumption of processed meat cannot be treated separately, owing to the lack of data. Therefore, »consumption of meat» refers in each case to the total consumption of fresh and processed meat. This presents some difficulties, which are discussed in Chapter 9.

At this point we have to consider the problem caused by inflation, which was quite notable during the research period. In the diagram it is indicated by the box of general price level, by which no particular price level is meant here. The effect of inflation is obviously felt differently at different levels of the market structure. At the producer level the question is one about the relative prices of different products and at the consumer level about the relative prices of consumer goods. Accordingly, the deflator for the supply functions is the general producer price index of agricultural products, that for the other equations being the consumer price index (cost of living index). This procedure has been applied throughout the study, and it will be referred to only occasionally.

Arrows in Figure 5.1 indicate the direction of influence of each factor. The diagram is, however, only a simplified a priori approach to the whole problem and has to be verified statistically. It suggests that the following structural equations have to be derived: supply, export, import, demand, price margin, and producer price equations. Each of them is constructed separately in the subsequent sections. The definitions of the variables used for the construction of the models are those of the general demand and supply theory. The variables employed for estimation do not, however, completely correspond to the theoretical definitions (see Appendix I). 
PORK

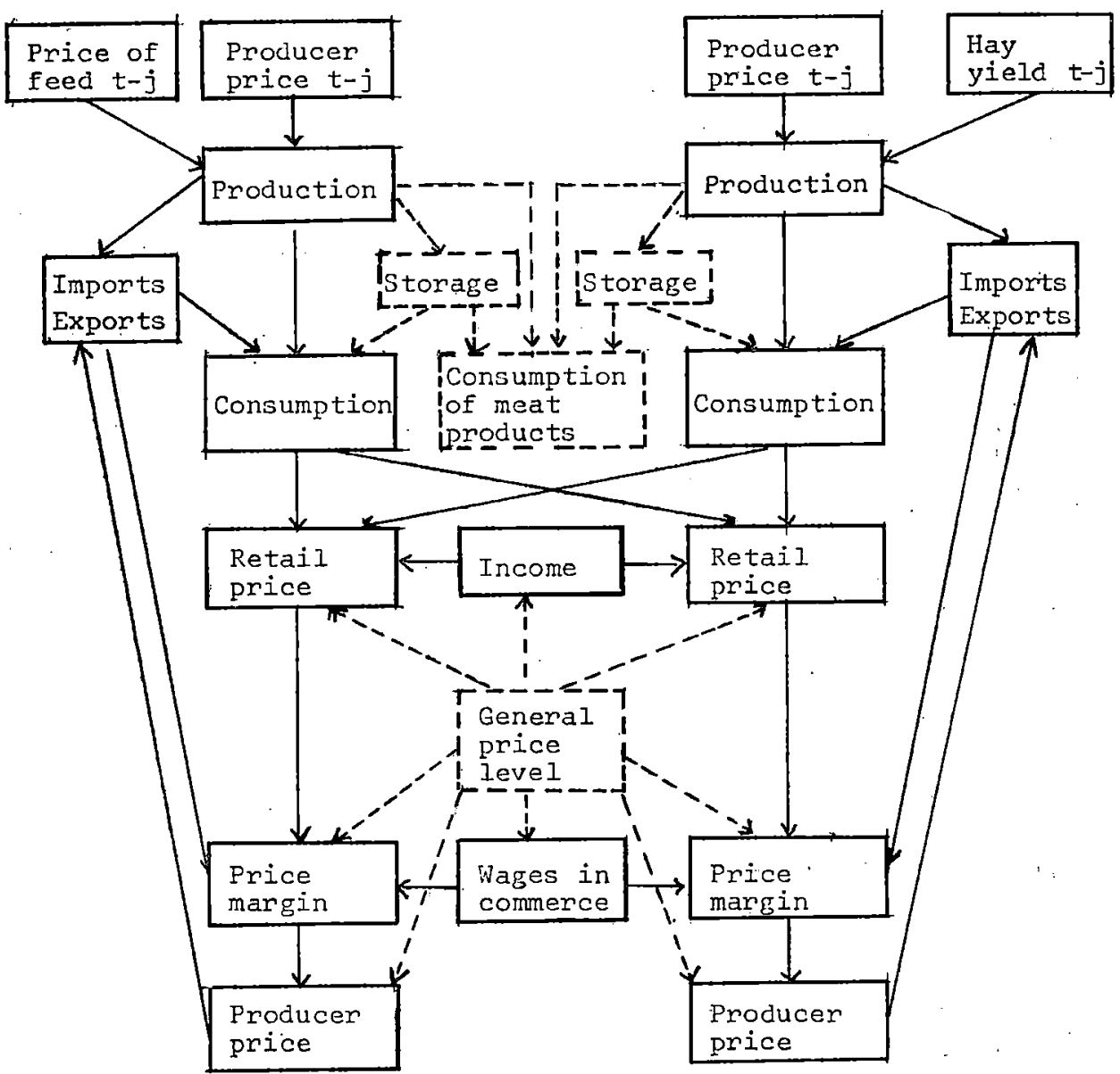

Figure 5.1. Market structure for pork and beef. The time period is $t$ if not otherwise indicated. Time lags are specified in sections $6.1-6.2$.

\section{Relationships}

\subsection{Supply of pork}

Since there is a recent study of pork supply by KAARLEHTo, ${ }^{1}$ it was not considered necessary to try to derive a new model for the present study. According to KaARLEHTO's study, the predictions of pork supply can be

1 Kantehto, Paavo: Sianlihan markkinoinnista Suomessa, op: cit. 
based either (a) on the producer price of pork and on the price of feed, (b) on changes in the number of sows in the May and December calculations, on the expectations of normal seasonal variations and on random fluctuations in the numbers of sows served, (c) on the fluctuations in the number of sows served. We will apply the first alternative here, since the prediction period, about a year, is the longest possible for that method. The model of this study was, however, constructed so, that the supply functions of pork and beef may be replaced by different types of supply functions without affecting the rest of the model.

According to KaARLEHTo's study, farmers' decisions to produce pork are based on the producer price of pork, the price of feed, the producer price of potatoes, and some unknown factors which cause an upward trend in the production and are taken into account by including a linear time trend variable in the function. The time lag of the variables is 5 quarters (denoted by $\mathrm{t}-5$ ), since the production time is about one year altogether, and farmers are supposed to base their decision on the information at their disposal, i.e., on the prices for previous quarter. Thus, the supply function can be written as follows: ${ }^{1}$

$$
X_{p}=f\left(Z_{1}, Z_{2}, Z_{3}, T\right)+u_{p}
$$

where $X_{p}=$ production of pork in th quarter

$\mathrm{Z}_{1}=$ producer price of pork $(\mathrm{t}-5)$

$\mathrm{Z}_{2}=$ price of feed $(\mathrm{t}-5)$

$Z_{3}=$ producer price of potatoes $(t-5)$

$\mathrm{T}=$ trend: $1,2, \ldots(1956 / \mathrm{I}=1)$

$\mathrm{u}_{\mathrm{p}}=$ disturbance term

Both the procedure through which feed prices were computed and the definitions of the other variables are given in Appendix I. In this study the prices involved in (6.1) are deflated by the producer price index of agricultural products.

Only this function was re-estimated, even though KaARLEHTo's study alșo includes a model which is based on the number of sows. For short run purposes it is also possible to estimate the pork supply by using the quarterly collected data on pigs of different ages.

1 The following notation of the variables is used: production (X), consumption (C), income (Y), price (P), imports (Im), and exports (Ex). The first subscript refers either to pork (p) or to beef (b) and the second subseript either to the retail $(r)$ or the producer $(p)$ price. In order to simplify the notation, Z's are used for all explanatory variables in the supply functions. 


\subsection{Supply of beef}

There are no previous quantitative studies on the supply of beef in Finland. It is well known, however, that beef is still mainly a by-product of milk production, and thus the quantity of beef supplied depends rather heavily on the stock of dairy cows and the conditions of milk production, mainly on feed supply. ${ }^{1}$ Thus it can be argued that in the short run the quantity of beef supplied depends negatively on the hay yield. If hay yields is good, more dairy cows may be kept for milk production and fewer old cows are slaughtered than usually. Also, more of young calves may be raised to bigger animals. Correspondingly, if the hay yields is small, fewer dairy cows may be left for milk production, and thus, beef production increases temporarily during that crop year. These short run variations in production have a countereffect in the next year. For example, if beef production falls owing to a good hay yield, then in the next year some old dairy cows which were kept in the previous year have to be slaughtered, in addition to the normal slaughterings. Moreover, the young beef animals kept in the previous year are obviously coming to the market, thus increasing the beef supply.

The number of dairy cows is, as suggested above, the first variable to be included in the equation.

The relationship between the quantity of beef supplied and hay yield is illustrated in Figure 6.1. There is an upward trend in beef production, which is obviously partly due to the slight upward trend in hay yields; but, as explained above, the annual deviations from the respective trends are negatively correlated. The relationship between these deviations is shown in Figure 6.2. The correlation is rather good, except for crop years 1962/63 and $1965 / 66$. Since the trend of hay yields is not linear, but rather curvilinear and concave from below, we cannot expect to have a perfect correlation between all deviations from linear trends. In any case, the picture seems to provide a good starting point for model building for the supply of beef.

For purposes of statistical analysis, the trend can be taken into account either (a) by first computing the trends of both variables and then the deviations from the trends and by employing these in the estimation or (b) by using the actual values of observations and including a trend variable assuming the values $1,2, \ldots$ etc. in the function to be estimated. The results are the same for both methods. ${ }^{2}$ In this study the trend variable method is used.

i In a recent article LANGeMeier and Thompson have partitioned the supply of beef into fed, domestic nonfed and import components and demand for beef into fed and nonfed components. This division does not seem reasonable in the Finnish case as yet, since feed cattle production is still rather small. Langemeier, Larry and Thompson, Russel G.: Demand, Supply and Price Relationships for the Beef Sector, Post-World War II Period. Journal of Farm Economies, Vol. 49, No. 1, Part I, February 1967, pp. 169-183.

a TINTNER, Gerhard: Econometrics. New York 1952, p. 303.

$3 \quad 8609-68$ 


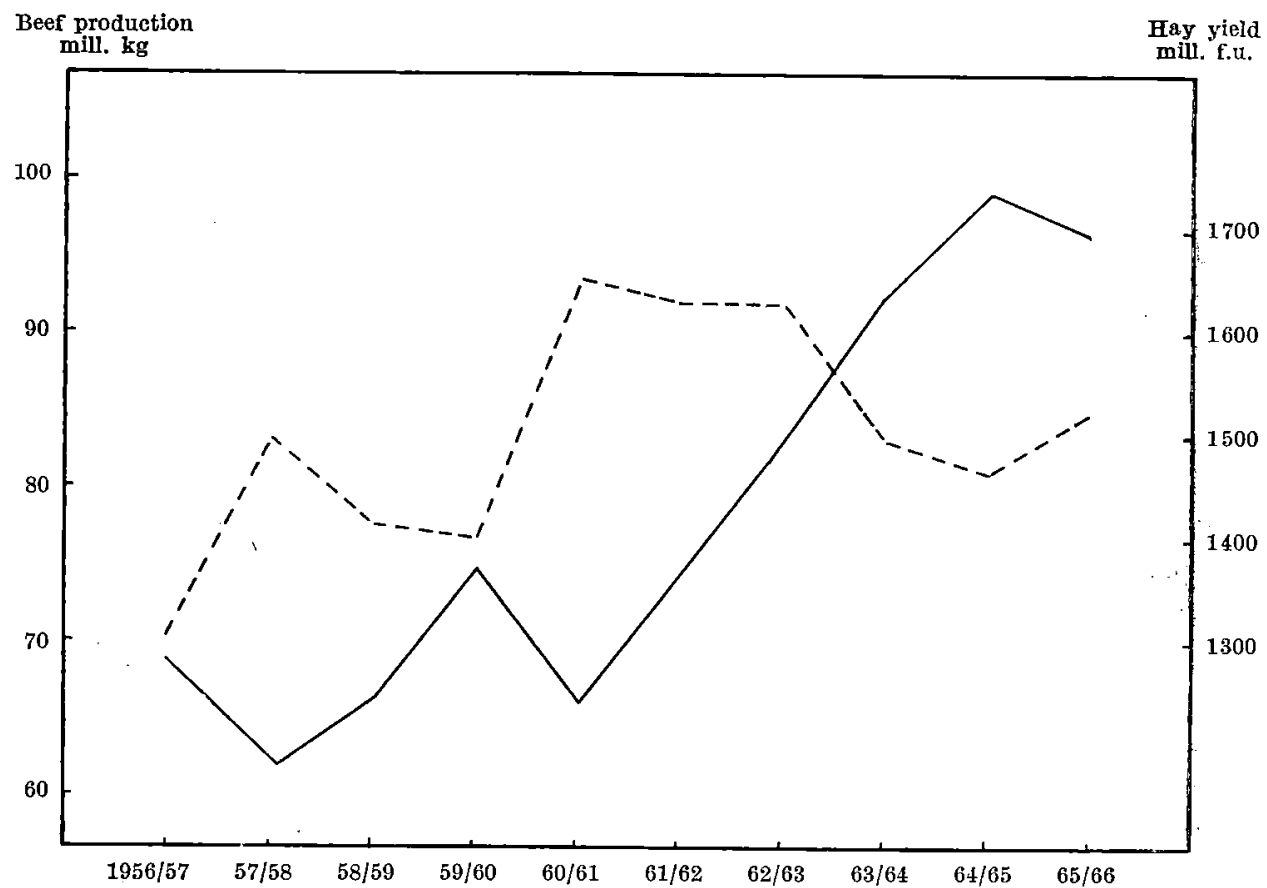

Figure 6.1. Beef production (-) and hay yields (- - - ), by crop years 1956/57-1965/66.

In measuring the hay yield variable for different time periods (quarters, half-years), it was postulated to have the same value for every quarter (halfyear) of the crop year beginning from the third quarter. The hay yield variable is therefore a kind of step variable, and this may obviously have some effect on the computed residuals of the estimated supply function.

The possible countereffect of the previous crop year's hay yield on the quantity supplied is tested by including the hay yield of the previous crop year, which also has the same value for every quarter (half-year) of the crop year.

During any particular crop year the hay yield seems to be the main determinant of beef production. Farmers may, however, respond to the producer price of beef in the next crop year by an appropriate adjustment of the intensity of hay cultivation and the acreage for hay. This suggest a time lag of one year in the producer price of beef, but a lag of two years was also employed in this study.

The model discussed and derived above can be written as

$$
X_{b}=f\left(Z_{4}, Z_{5}, Z_{6}, Z_{7}, Z_{8}, T\right)+u_{b}
$$




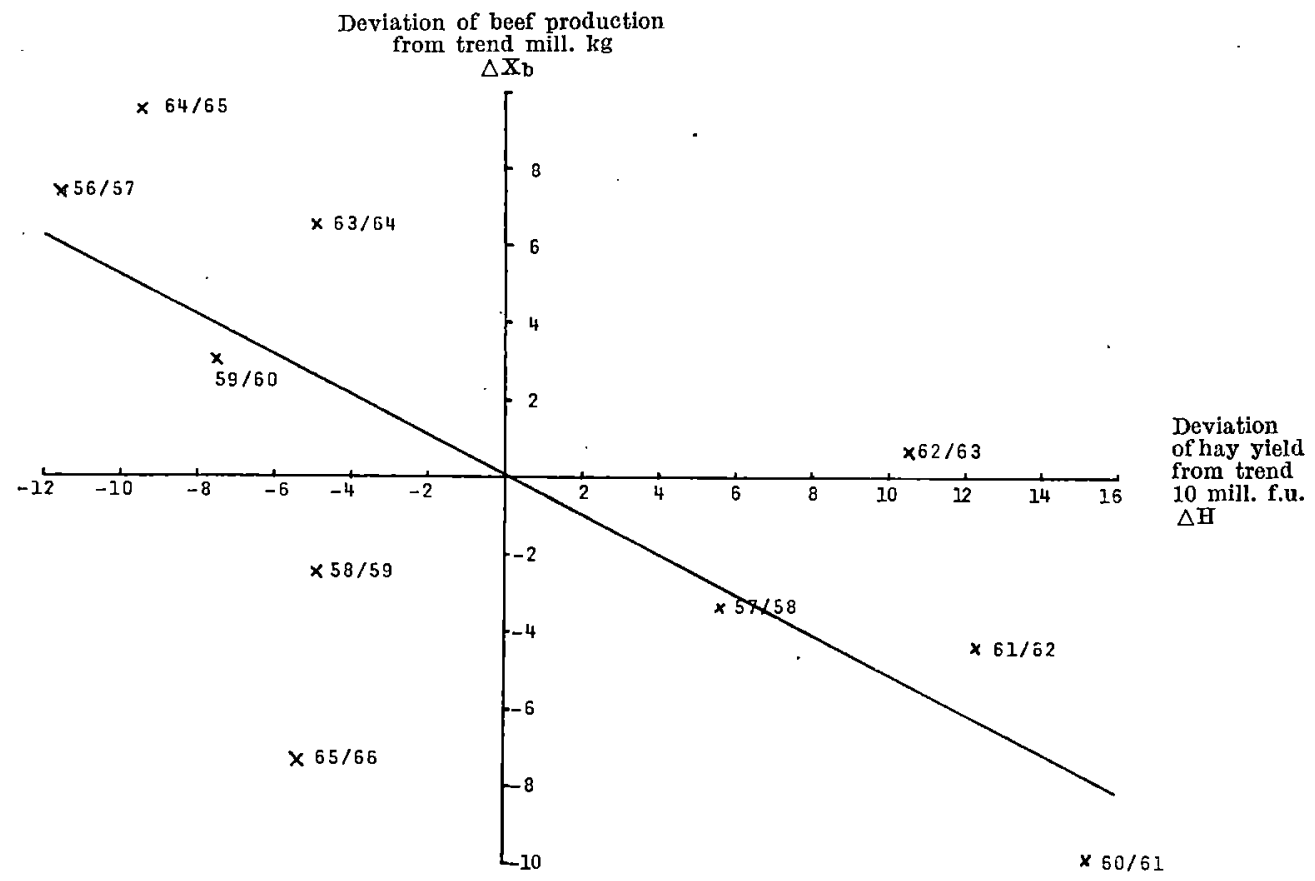

Figure 6. 2. Deviations of beef production $\left(\triangle \mathrm{X}_{\mathrm{b}}\right)$ and hay yields $(\triangle \mathrm{H})$ from their respective trends, by crop years $1956 / 57-1965 / 66$. The line drawn in the figure is a regression line $\triangle \mathrm{X}_{\mathrm{b}}=0.51 \triangle \mathrm{H}, \mathrm{r}^{2}=0.53$. (0.16)

where $\mathrm{X}_{\mathrm{b}}=$ current beef production

$Z_{4}=$ number of dairy cows

$\mathrm{Z}_{5}=$ hay yield at the beginning of the orop year (July-June)

$Z_{6}=$ lagged hay yield $\left(=Z_{5} t_{-4}\right)$

$\mathrm{Z}_{7}=$ producer price of beef lagged 4 quarters $\left(=\mathrm{P}_{\mathrm{bpt}-4}\right)$

$\mathrm{Z}_{8}=$ producer price of beef lagged 8 quarters $\left(=\mathrm{P}_{\mathrm{bpt}-8}\right)$

Some modification of this basic model are given in the empirical part of the study.

The producer price of milk is not included as an explanatory variable in the supply function for beef. In Finland, where beef production is tied to the number of dairy cattle, it is obvious that the milk price has two effects opposed in direction on the supply of beef. In the short run the relationship is negative: a decrease in milk price is likely to increase beef production. In the long run, however, the production of beef will decrease, since the smaller number of cows may also indicate a smaller number of calves. Correspondingly, an increase in milk price will in the short run decrease the supply of beef; but in the long run, after the number of dairy 
cows has increased, beef production may increase with the increasing number of ealves. However, since the slaughterings of dairy cows account for about a third of the total beef production, the above line of argument may not be completely valid; the distribution of slaughtering of younger animals, calves, beef calves, etc. may change, thus affecting the quantity of beef supplied. Moreover, although the question is one concerning the most efficient use of limited resources (feed) either to produce milk or meat, these two lines of production cannot yet be separated entirely from each other in Finland.

It did not seem possible to formulate any reasonable hypothesis for this study, mainly because the Finnish agricultural price system has guaranteed the stability of the price for milk. It has been unnecessary for farmers to pay much attention to millk price; so far, milk production has generally been regarded as more advatageous, compared with beef production, because on small farms milk production results in higher labor income than meat production does.

\subsection{Demand for pork}

The general theory of demand states that the consumption of a commodity is a function of its own price, the prices of its substitutes and complements, and the disposable income, a function which we will call an ordinary demand function. In terms of model building this implies that consumption is a dependent variable and the prices and disposable income are independent (explanatory) variables, determined by factors external to the model and affected in no way by consumption. However, the supply of most agricultural products is rather inelastic in the short run, the length of the "run» being different for differend products. The supply of cereals, for example, is determined by the acreage planted and by weather conditions; i.e., it is fixed for any particular crop year. As a rule, in countries where only one crop is harvested every year, it cannot respond to the producer price until the next summer. Of course, a part of the crop may be left unharvested if the producer price is too low, and a part may be stored by farmers, to be marketed later on.

Pork production takes about one year from the date of the production decision to the date when the quantity comes to the market. The possibilities to adjust the quantity to the current price are quite small. Slaughtering may be stopped for some weeks, but not for many months. Production becomes unprofitable if hogs are fed to heavy weights, since there is a price differentiation system, so that the highest price is paid for a certain weight class. Therefore, the quantity supplied during a quarter may be considered to be determined by the producer price and other factors prevailing at the date of decision making; and the producer price, in turn, responds to the quantity 
supplied. This was also confirmed by statistical analysis. The attem $\rho$ ts to estimate the short run elasticity of supply with respects to the current producer price of pork by including it in the supply function were not successful. ${ }^{1}$

These considerations suggest that the demand function for pork has to be estimated with the retail price of pork as the dependent variable and the quantity consumed as the independent variable, as Figure 5.1 indicates. Also the consumption of beef and the disposable income will be included in the function. As to the consumption of other kinds of meat, for example broiler, ${ }^{2}$ it may affect the retail price of pork to some extent, but since this consumption is rather small and, for example, broiler is a new product the market of which is not yet well established in Finland, it was not included in the demand function.

In Section 4.1 the elasticity of demand for pork with respect to the disposable income was assumed to be low, since the per capita consumption was rather constant during the sample period. It is, however, necessary to test this assumption through a multiple regression analysis, since the consumption of beef, which increased by about 30 per cent, may have diminished. the demand for pork. Figure 6.3 illustrates the income effect on the demand for pork. A line has been drawn through every price-consumption point, indicating the location of the demand function with a tentive average price flexibility - 1 . These lines will be used to examine how the upwards and downwards shifts indicated by them conform to the changes in the real disposable income, i.e., to represent the effect of income on the demand for pork. It is seen that the demand for pork fell between 1957 and 1959 , obviously as a result of the simultaneous decrease in the real disposable income (see Table 6.1, where the wage index of all salary and wage earners as deflated by the cost of living index is given, indicating the movements of the real disposable income). Nevertheless, the demand for pork also fell in 1960, although the real income began to increase. The shift of the demand function is small, however, and it may have been occasioned by the increase in beef consumption. Shifts of the demand function between 1959 and 1960 and between 1961 and 1962 brought the demand function back to the 1956 level. Since the real income level rose at the same time by about 17 per cent,

1 Attempts have been made to estimate the short run response by using a model where the dependent variable is the average slaughter weight of hogs and the producer price of pork is the independent variable. These short run elasticity estimates range from 0.04 to 0.08 . See HarLow, Arthur A.: Factors Affecting the Price and Supply of Hogs. U.S. Dept. of Agr., Technical Bulletin 1274. Washington 1962 ; pp. 40-41. HarLow has also published the main results of his study in an article entitled A Recursive Model of the Hog Industry. Agricultural Economics Research, U.S. Dept of Agr., Vol. XIV, No. 1, January 1962, pp. 1-12.

In the present study the application of the model did not, however, yield any significant result; $\mathrm{r}^{2}$ was only 0.015 .

2 See, for example, Stanton, B. F.: Seasonal Demand for Beef, Pork, and Broilers. Agricultural Economics Research, U.S. Dept. of Agr., Vol. XIII, No. 1, January 1961, pp. 1-14. 


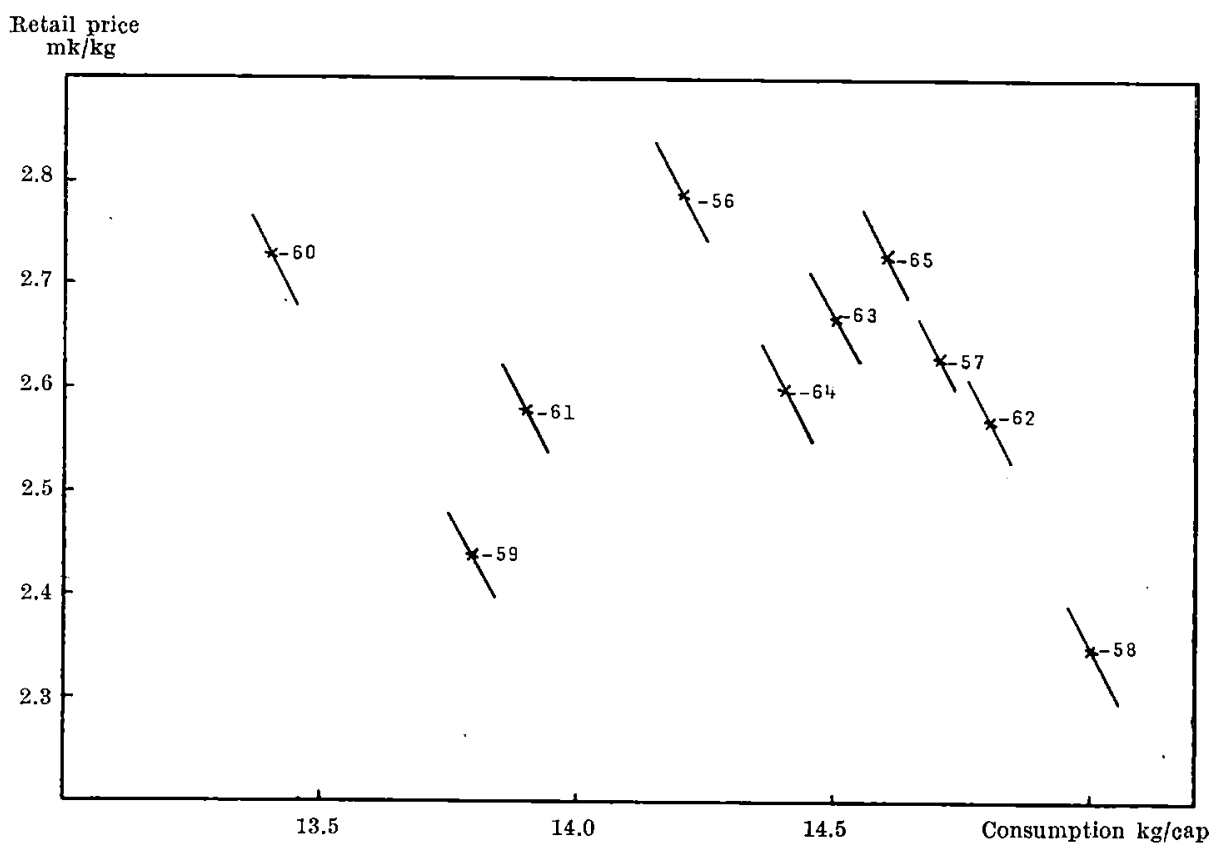

Figure 6.3. Demand for pork. The relationship between the retail price of pork as deflated by the cost of living index and the per capita pork consumption, in 1956-65.

but only a small change took place in demand, either the income elasticity of the demand for pork was low or the cross elasticity of the demand for pork with respect to the consumption of beef was considerable. These assumptions will be tested statistically.

The demand function discussed above may be written as

$$
P_{p r}=f\left(C_{p}, C_{b}, Y\right)+u_{p r}
$$

where $\mathrm{P}_{\mathrm{pr}}=$ deflated retail price of pork

$\mathrm{C}_{\mathrm{p}}=$ per capita consumption of pork

$\mathrm{C}_{\mathrm{b}}=$ per capita consumption of beef

$Y=$ real disposable income

Table 6.1. The wage index of all salary and wage earners as deflated by the cost of living index

\begin{tabular}{c|c|c|c|c|c|c|c|c|c|c}
\hline Year & 1956 & 1957 & 1958 & 1959 & 1960 & 1961 & 1962 & 1963 & 1964 & 1965 \\
\hline Index ........... & 100 & 95 & 93 & 96 & 98 & 104 & 106 & 110 & 113 & 117
\end{tabular}


Since consumption is the sum of production, changes in storage holdings (dS) and net imports (see Figure 5.1),

$$
\mathrm{C} \equiv \mathrm{X}+\mathrm{dS}+\mathrm{Im}-\mathbf{E x}
$$

the model (6.3) implicitly assumes that changes in any of these components have a similar effect on the retail price. This appears a rather plausible assumption, since (6.3) is a function of the reactions of consumers, to whom it is indifferent how the quantity supplied for consumption is formed. However, these components have very often been included separately in the demand functions to be estimated. The argument in support of this procedure has been (or can be supposed to have been) that the changes in storage holdings or in imports and exports, which are marginal factors, affect the retail price (or producer price) more than do similar changes in production.

To test the hypothesis of the similarity of the effects of various components, an equation (6.5), where production and net imports were allowed to react independently, will be estimated. In terms of the regression coefficients, the assumption means that the coefficients for the production and net imports variables will be equal. The equation to be estimated is as follows:

$$
P_{p r}=f\left(X_{p}, X_{b}, \operatorname{Im}-E x_{p}, \operatorname{Im}-E x_{b}, Y\right)+u_{b}{ }^{\prime}
$$

where $\operatorname{Im}-\mathbf{E x}_{\mathrm{p}}=$ net imports of pork $\operatorname{Im}-\mathbf{E x}_{\mathbf{b}}=$ net imports of beef

the other variables being the same as before. As for the net imports the reader is referred to Section 6.5.

\subsection{Demand for beef}

Structure of the demand equation for beef is basically same as that for pork. The explanatory variables are the same as those in (6.3) and (6.5); only the dependent variable has to be replaced by the retail price of beef as deflated by the cost of living index.

Figure 6.4 illustrates the effect of income on the demand for beef. Again, lines representing a demand function with an average price flexibility equal to -1 are drawn through every price-consumption point. The shifts of the demand function are in good agreement with the changes in income: at first downwards, as income falls, and then upwards, as income increases. Exceptions are only provided from 1958 to 1959 and from 1961 to 1962 ; the shifts in the demand function were downwards, although income moved upwards. The tentative price flexibility -1 need not, however, be the true 


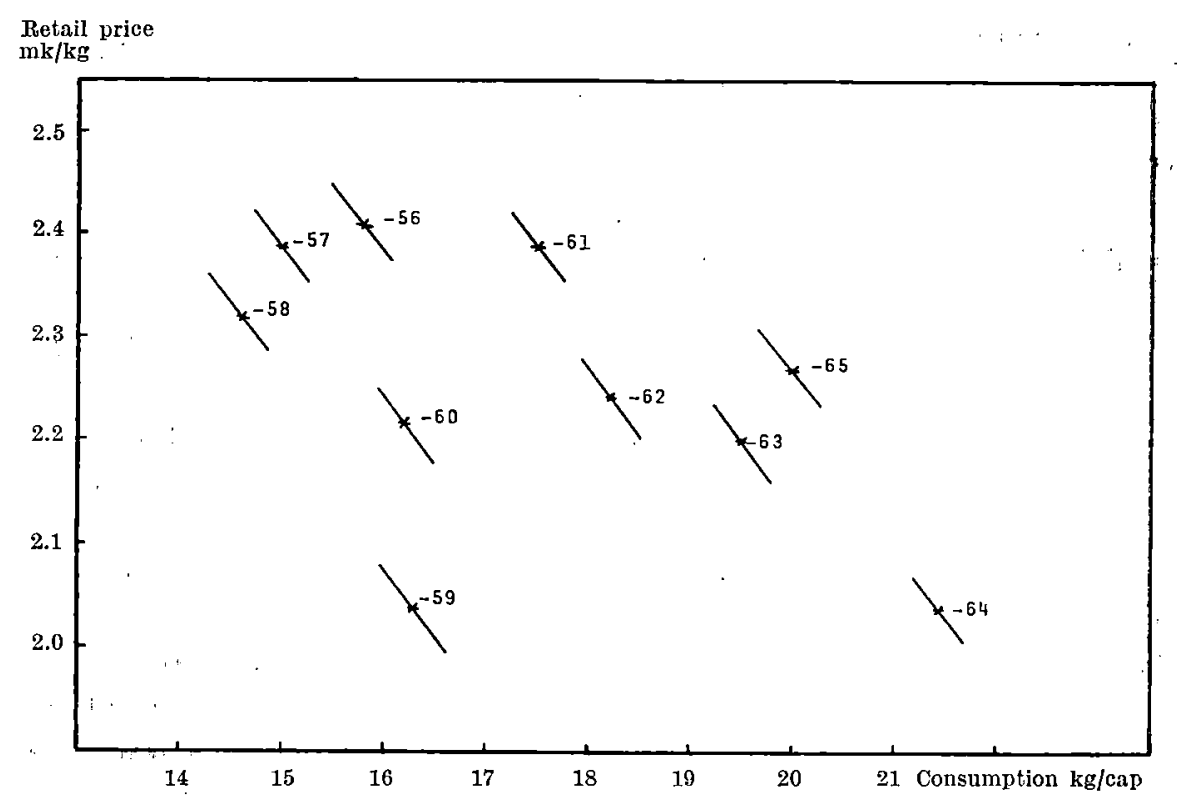

Figure 6.4. Demand for beef. The relationship between the retail price of beef as deflated by the cost of living index and per capita beef consumption, in 1956-65.

one; and therefore, if some other value of price flexibility were used, the picture would be different. A possible substitute effect of pork consumption has also to be taken into account when the shifts of the demand function for beef are examined. For example, in 1962 pork consumption rose by almost $1 \mathrm{~kg}$ per capita, and this was likely to affect the demand for beef to some extent.

\subsection{Imports and exports}

The structure of the Finnish import and export markets differ greatly from that of free trade markets as became clear in the Introduction. A typical free trade import-export function includes, apart from the producer or wholesale price for the commodity in question, the corresponding world market price plus transportation costs and perhaps a number of other variables. Finnish meat imports and exports do not depend on the world market prices at all. Although the world market prices are invariably' lower than the domestic wholesale prices, exports are made possible by subsidies, whereas imports are controlled by quantitative restrictions and variable import levies. The only factors which might change the situation would be unavailability of meat in the world market for imports or the absence of markets (buyers) for exports. 
As already stated, imports and exports are employed to achieve the target prices set for pork and beef for each particular crop year. At present a 5 per cent variation around the target price is allowed, but if the actual producer price exceeds these limits, the government has to take measures to have the producer price to return to the 5 per cent range. If the price is too low, exports are to be made possible by subsidies; and if the price is too high, imports are to be permitted.

The price system presented above can be summarized in the form of the following functions:

$$
\begin{array}{ll}
\mathrm{Im}=f\left(\mathrm{P}_{\mathrm{pt}}-1.05 \mathrm{TP}_{\mathrm{t}}\right) & \mathrm{P}_{\mathrm{pt}}>1.05 \mathrm{TP}_{\mathrm{t}} \\
\mathrm{Ex}=\mathrm{f}\left(\mathrm{P}_{\mathrm{pt} t}-0.95 \mathrm{TP}_{\mathrm{t}}\right) & \mathrm{P}_{\mathrm{pt}}<0.95 \mathrm{TP}_{\mathrm{t}}
\end{array}
$$

where $\mathrm{P}_{\mathrm{pt}}=$ the actual producer price (of pork or beef) and $\mathrm{TP}_{\mathrm{t}}=$ the corresponding seasonally adjusted target price. These functions determine, in principle, meat imports and exports. If the producer price is within the range, no foreign trade in meat should be allowed. However, a part of the foreign trade (exports) in both pork and beef may be predetermined by trade agreements concluded for the future year(s). The quotas have to be fulfilled, even if the price situation would not allow it. It is clear that this part of exports cannot be explained by the above functions, which therefore cannot completely explain the imports and exports which have actually occurred. Even the average producer price of pork has twice been outside the range for an entire crop year; in 1957/58 it was about 11 per cent below and in $1959 / 60$ about 5.4 per cent above the target price. ${ }^{1}$

As to the estimation of the net imports function, it should be borne in mind that the price range system has been valid in its present form for beef only since 1962/63. Therefore, the estimation of the parameters of the model is not yet possible, because of lack of data. But it is questionable whether it is possible even in the case of pork: even quarterly data are too aggregated to reveal the difference between target prices and actual producer prices. This complication is due to foreign trade in pork since the producer price responds rather quickly to exports and imports. Moreover, the price development can often be anticipated, and a decision to import or export is made before the price situation would suggest it. Also, since some parts of exports have been predetermined by trade agreements, attempts to estimate import and export functions of type (6.6) and (6.7) must be given up

1 Maataloustuotteiden hinnanmuodostuskomitean osamietintö II. Komiteanmietintö 1966: B 12, Helsinki 1966, p. 41.

$4 \quad 8609-68$ 
Since imports and exports of pork or beef may not be considered to be wholly predetermined, two alternative equations, which are valid for both products were constructed to replace the functions (6.6) and (6.7):

$$
\begin{aligned}
& \operatorname{Im}-\mathrm{Ex}=\mathrm{f}\left(\mathrm{P}_{\mathrm{p}}\right)+\mathrm{u}_{\mathrm{im}} \\
& \mathrm{Im}-\mathrm{Ex}=\mathrm{f}(\mathrm{X}, \mathrm{Y})+\mathrm{u}_{\mathrm{im}}^{\prime}
\end{aligned}
$$

Here the dependent variable is net imports. No reason was found why imports would react differently than exports, and no variables were found which might not belong to both import and export functions. Therefore we may use net imports as the dependent variable here and as an explanatory variable in other functions. This also reduces the number of functions to be estimated by two.

The first equation (6.8) implies that net imports are determined by the producer price alone, leaving out the target price, which was included in the equations (6.6) and (6.7). The second model (6.9) assumes that net imports are a function of production and real disposable income. If production increases (decreases) other things being constant, exports (imports) will also increase. To be logical Im-Ex should be negatively correlated with production, but as is obvious, positively correlated with income, the increase of which raises consumption.

The basis for the construction of both equations (6.8) and (6.9) becomes more explicit when the structure of the whole market model is considered. Be it noticed that Figure 5.1 includes both functions (6.8) and (6.9).

\subsection{Price margins}

By "price margin" is meant in this study the difference between the retail and producer prices. The price margin function is usually defined with the producer price as the dependent variable and the retail price and other possible factors as the explanatory variables. Here the price margin itself is used as the dependent variable.

As was seen from Table 4.3, the price margins have increased. There are several reasons for that. Rationalization may not have been efficient enough to prevent the increase in costs, of which the wages in retail trade, processing and transportation make up a major part. The margins also reflect the increased customer services provided by retailers in the form of cold storage, packing, etc. It is impossible to include all these factors in the price margin function, in the absence of relevant data. Only the wages in commerce were available for this study. They may serve as the common variable for all costs of processing, transportation, etc., and for the wages in commerce. 
The retail price level is also a determinant of the price margin, since it is reasonable to assume that the retail price margin is a fixed percentage (even though slightly variable through time) of the retail price. This assumption is tested by employing the linear function $\mathrm{M}=\mathrm{a}+\mathrm{bP}_{\mathbf{r}}(\mathrm{M}=$ the price margin and $\mathrm{P}_{\mathrm{r}}=$ the retail price). If $\mathrm{a}=0, \mathrm{~b}$ gives the percentage ratio of $M$ to $\mathrm{P}_{\mathrm{r}}$. If $\mathrm{a} \neq 0$, the percentage $\frac{\mathrm{M}}{\mathrm{P}_{\mathrm{r}}}=\frac{\mathrm{a}}{\mathrm{P}_{\mathrm{r}}}+\mathrm{b}$ is an increasing function of $\mathrm{P}_{\mathrm{r}}$ its maximum being $\mathrm{b}$.

It may be assumed that the price margin is also a function of net imports of pork (or beef). The import price (world market price) has been and will very probably be lower than the domestic producer price. When imports are permitted, a variable import levy is charged, which is based on world market quotations and the domestic producer price. Since the actual import price may sometimes be lower than the world market quotation price, there may be some gains from imports to the importing firms. Because of the competition between different slaughterhouses these firms would, therefore, be able to pay a higher producer price. Other slaughterhouses would then follow suit with the result that the producer price would rise. This rise has, however, no effect on the retail price, and thus the price margin decreases. When a need for exports arises, there will be pressure for lowering the producer price because of the expectations that excess supply will continue and losses will become evident in the course of time, with the decreasing producer price. Storage costs may also then press the producer price downwards.

The above considerations suggest that the price margin function for pork is (as Figure 5.1 indicates)

$$
\mathrm{M}_{\mathrm{p}}=\mathrm{f}\left(\mathrm{W}, \mathrm{P}_{\mathrm{pr}}, \mathrm{Im}-\mathbf{E x}_{\mathrm{p}}\right)+\mathrm{u}_{\mathrm{mp}}
$$

and for beef

$$
\mathrm{M}_{\mathrm{b}}=\mathrm{f}\left(\mathrm{W}, \mathrm{P}_{\mathrm{br}}, \mathrm{Im}-\mathrm{Ex}_{\mathrm{b}}\right)+\mathrm{u}_{\mathrm{mb}}
$$

where $M_{p}=$ price margin for pork

$\mathrm{M}_{\mathrm{b}}=$ price margin for beef

$\mathrm{W}=$ wage level in commerce

the other variables being the same as before.

WAANANEN and KAARLEHTo found that the price margin for eggs is larger when the retail price is going down than when it is going up. ${ }^{1}$ This

1. WaAnanes, Martin and KaARlehto, Paavo: Marketing Margins for Eggs in Finland. Washington Agricultural Experiment Stations, Technical Bulletin 45, April 1965, pp. 11-12. KaARLEHTo has also used the number of months during which the rise or fall has taken place contjnously as an explanatory variable in the price margin function. Sianlihan markkinoinnista Suomessa, op. cit., pp. $46-49$ or p. 72 . 
phenomenon was quantified through regression analysis by employing the dummy variable method, which gave two parallel regression lines, one for falling and another for rising retail prices. The application of the method to the data of the present study did not, however, yield any significant results, although there was some indication that the behavior of the variables was similar to that discovered by WAANANEN and KAARLEHTO. It is possible that the fundamental reason for the phenomenon is the supply condition which is reflected by production, imports and exports. ${ }^{1}$

\subsection{Producer prices}

As regards price formation our model construction is based on the assumption that price determination takes place at the retail level: the retail price $\left(P_{r}\right)$ is first determined by the demand and the quantity supplied, and then the producer price $\left(\mathrm{P}_{\mathrm{p}}\right)$ is derived from it by subtracting the price margin (M) prevailing at the moment to obtain:

$$
\mathrm{P}_{\mathrm{p}} \equiv \mathrm{P}_{\mathrm{r}}-\mathrm{M}
$$

which applies to both products. It differs from the preceding equations, in that it is an identity and, thus, need not be estimated.

\section{The form of the functions}

Functions linear in the variables are applied in this study. The use of simultaneous models requires that the functions be linear in the variables, either in absolute terms or in logarithms, since otherwise difficulties are encountered in evaluating the Jacobian of the transformation connecting the disturbances with the endogenous variables ${ }^{2}$ or in deriving the reduced form of the model. ${ }^{3}$ The choice of the form of the functions is therefore limited. This difficulty may be avoided to some extent by using linear approximations for the combined variables, such as products or ratios of variables. ${ }^{4}$ In this study there is no need to do so.

1 For example, James P. Houck applied a function with the production and the logarithm of the time series $(t=1,2, \ldots)$ as the explanatory variables in the price margin function for soybeans. Demand and Price Analysis of the U.S. Soybean Market. University of Minnesota, Agricultural Experiment Station. Technical Bulletin 244, June 1963, p. 28.

2 The Jacobian of the transformation is the matrix of partial derivatives of $u_{t}$ with respect to $\mathrm{Y}_{\mathrm{t}}$. KLEIN, Lawrence R.: A Textbook of Econometrics. Evanston, Ill. 1956, p. 120.

$\mathbf{3}$ If the matrix $\mathbf{B}$ is nonsingular, the structural model $\mathbf{B Y}+\mathbf{C Z}+\mathbf{u}=\mathbf{0}$ may be premultiplied by the inverse matrix $\mathbf{B}^{-1}$ :

$$
\mathbf{Y}+\mathbf{B}^{-1} \mathbf{C Z}+\mathbf{B}^{-\mathbf{1}} \mathbf{u}=\mathbf{0} \text {. }
$$

This is called the reduced form of the model. See, for example, Johnston, J.: Econometric Methods. New York 1963, p. 107.

4 See, for example, KLeIN, op. cit., pp. 120-121. The problem is also dealt with in a recent article by Eisenpress, Harry and GreenstadT, John: The Estimation of Nonlinear Econometric Systems. Econometrica, Vol. 34, No. 4, October 1966, pp. 851-861. 
The choice of the form of the functions is mostly subjective. Simultaneous determination as well as the number of variables in each function make it difficult to use graphic inspection for the selection of the form of the functions. There are also no exact theoretical criteria for selection. Some characteristics of the functions may, however, be used in judging their suitability for application in each case. The estimators of the elasticities given by each function may serve as the criteria for our model. Double-logarithmic functions, where all variables are expressed in logarithms, yield constant elasticities, but the elasticities of none of the functions in the models are likely to be constant. The elasticities computed from linear functions are more plausible, since they depend on the level of the explanatory variables (see Chapter 13). Nevertheless, this property does not necessarily imply that linear functions are here the best possible, for there are many other functions possessing the same property. Anyway, this was one reason for the use of linear functions. Another was the inclusion of $\mathrm{Im}-\mathrm{Ex}$ variables, which may have negative values and therefore cannot be transformed into logarithms. As stated above, a mixture of linear and logarithmic variables is not fit for simultaneous models. For single equations it might, of course, be possible. 


\section{MULTI-EQUATION MODELS}

\section{General}

The first approach to the estimation of the parameters of each structural equation would be to apply the method of least squares. Some conditions have, however, to be fulfilled in order for it to be possible to evaluate the estimates with respect to bias, consistency, efficiency, or any other statistical properties considered necessary or desirable. ${ }^{1}$ The assumptions refer to the disturbances $u_{t}$, which are assumed to be normally distributed with a zero mean and a constant variance and which are not serially correlated. ${ }^{2}$ They are also assumed to be independent of the explanatory variables. It is this assumption which is often not valid and which leads to multi-equation systems, simultaneous or recursive, and to the corresponding estimation methods.

In a simultaneous model the dependent variables are determined, as the name implies, simultaneously by the predetermined variables. ${ }^{3}$ Endogenous variables can also be explanatory variables in some or all other structural equations, which makes the disturbance terms correlated with the explanatory variables; and, thus, the least squares estimates may be subject

1 See, for example, Koopmans, Tjalling C. and Hood, Wm. C.: The Estimation of Simultaneous Linear Economic Relationships. Hoon, Wm. C. and Koopmans, Tjalling C. (eds.): Studies in Econometric Method. Cowles Commission for Research in Economics, monograph No. 14. New York 1953 , pp. $128-130$.

2 Johnston: op. cit., p. 107.

3 A structural equation includes (a) endogenous variables which are to be explained by the model, (b) exogenous variables whose purpose is to explain the generation of the endogenous variables, and (c) unobserved variables $\mathrm{u}_{t}$, to be called disturbances, which represent the aggregate effects of additional unspecified exogenous variables on the economic decisions expressed by the
relation.

When a model is formulated, it is often also necessary to use lagged endogenous variables as explanatory variables. These can be considered from the estimation point of view as independent variables. Thus we can classify the variables as follows:

$$
\begin{aligned}
& \text { Dependent variables } Y_{t} \\
& \text { Predetermined variables } Z_{t} \\
& \text { Disturbances } u_{t}
\end{aligned}\left\{\begin{array}{l}
\text { endogenous } Y_{t} \\
\text { exogenous } X_{t} \\
\text { lagged exogenous } X_{t-i}
\end{array}\right.
$$

Koopmans and Hoon: op. cit., pp. 123-124, or Malinvaud, E.: Statistical Methods of Econometrics. Studies in Mathematical and Managerial Economics, Volume 6. Amsterdam 1966, p. 60, or Goldberger, Arthur, S.: Econometric Theory. New York 1964, p. 294. 
to bias. Simultaneous estimation of a system or set of equations brings with it, however, new requirements to be fulfilled: the disturbances $u_{t}$, of different equations have to be independent of each other. If this assumption is not valid, the estimates obtained by multi-equation methods are also biased.

A recursive model consists of a set of equations which form a causal chain, so that the first equation contains only one endogenous variable, the dependent variable $Y_{1}$, the second one explains $Y_{2}$ in terms of $Y_{1}$ and predetermined variables, the third one explains $Y_{3}$ in terms of $Y_{1}$ and $Y_{2}$ and predetermined variables, and so on. Each equation may include only those endogenous variables which have appeared in previous equations. ${ }^{1}$ This means that the matrix of the coefficients of the dependent variables, B, is subdiagonal, i.e., it has zeros above the diagonal. Here, the following further requirement has also to be valid: The Jacobian of the transformation connecting the disturbances with the endogenous variables has to be triangular and equal to unity. If the model is linear in the variables, the Jacobian is identical with the matrix of the coefficients of the endogenous variables, and thus, this mathematical condition is easily checked. ${ }^{2}$

Large economic models, which consist of many equations and are therefore very complex to estimate, have led to block-recursive models. These consist of several submodels which may be either recursive or simultaneous and which form a total model which is recursive, in the sense that the matrices of the coefficients of the submodels above the main diagonal are zero matrices. If the submodels are denoted by A, B, C, etc., the block-recursive model may be written as ${ }^{3}$

$$
\left[\begin{array}{cccccc}
A & O & O & O & \ldots & O \\
B & C & O & O & \ldots & O \\
D & E & F & O & \ldots & O \\
\ldots & \ldots & \ldots & & & \\
G & H & & & \ldots & I
\end{array}\right]
$$

1 A recursive model can be written as follows:

$\mathrm{Y}_{1}=\mathrm{f}_{1}\left(\mathrm{Z}_{1}\right)+\mathrm{u}_{1}$

$\mathrm{Y}_{2}=b_{21} Y_{1}+f_{2}\left(Z_{i}\right)+u_{2}$

$\mathrm{Y}_{3}^{2}=\mathrm{b}_{31} \mathrm{Y}_{1}+\mathrm{b}_{32} \mathrm{Y}_{\mathrm{2}}+\mathrm{f}_{3}\left(\mathrm{Z}_{\mathrm{i}}\right)+\mathrm{u}_{3}$

$\ddot{Y}_{G}=\ddot{b}_{G 1} \ddot{Y}_{1}+b_{G 2} Y_{2}+\ldots \ldots+b_{G, G-1} Y_{G-1}+f_{G}\left(Z_{i}\right)+u_{G}$,

where $f_{J}\left(Z_{i}\right)$ are some functions of the predetermined variables. WoLD, Herman: Forecasting by the Chain Principle. Wors, Herman O. A. (ed.): Econometric Model Building. Contributions to Economic Analysis XXXVI. Amsterdam 1964, p. 17.

a Harlow: Factors Affecting..., op. cit. p. 49.

3 Duesenberry, James S. and Klein, Lawrence R.: Introduction: The Research Strategy and Its Application. Duesenberry et.al. (eds.): The Brookings Quarterly Economic Model of The United States. Amsterdam 1965, p. 27. 
As some of the coefficients below the main diagonal in a simple recursive model may be zeros, so some of the matrices below the main diagonal in (8.1) may also be zero matrices. A submodel may also consist of a single equation.

Even though there has been much dispute as to whether a recursive or simultaneous model is the appropriate one in examining interrelationships of economic phenomena, the block-recursive approach is a good indication of the fact that both are legitimate if only the necessary mathematical conditions are fulfilled.

Several methods are available for the estimation of the parameters of simultaneous models, such as two-stage or three-stage least squares, the limited information or the full information maximum likelihood method, the minimum variance method, generalized least squares, etc. ${ }^{1}$ The twostage least squares method has become the one most frequently used, since it is easy to apply and its estimates fulfill at least the minimum requirement of consistency.

The method of least squares is applicable to a recursive model if the disturbances $u_{t}$ of different equations are independent of each other. ${ }^{2}$ If this condition is not satisfied, the values calculated from the successive functions may be used for the endogenous variables which appear as explanatory variables in the equation to be estimated. ${ }^{3}$ This resembles the two-stage least squares method, where the calculated values of the explanatory endogenous variables are generated by all predetermined variables in the model. ${ }^{4}$ The same applies to block-recursive models. The endogenous variables from the successive block serving as independent variables in the block under consideration are usually applied as such, but the colculated values should be used if the disturbances between the blocks are not independent. ${ }^{5}$

\section{The character of the multi-equation models}

When the character of a multi-equation model is examined, attention is paid to the causal direction of the influence of the variables in the functions. Using a traditional example, the simultaneous model of demand and supply can be written as

$$
\begin{array}{ll}
q_{t}=a+b p_{t}+u_{1 t} & \text { (supply) } \\
p_{t}=c+d p_{t}+u_{2 t} & \text { (demand) }
\end{array}
$$

Here the quantity supplied and the price are determined simultaneously, and thus, the causal relationship is mutual in both equations:

1 See, for example, JoHnston: op. cit., pp. 252-268.

2 WoLD: op. cit., p. 22.

2 HarLow: op. cit., pp. $48-49$.

3 JoHnston: op. cit., pp. $258-260$.

4 Dueșenberry and Klein: op. cit., p. 29. 
current quantity supplied $\rightleftarrows$ current price

This dependence makes the disturbance terms correlated with the explanatory variable, and then the method of least squares will give biased estimates of the regression coefficients.

In the recursive model

$$
\begin{array}{ll}
q_{t}=a+b p_{t-1}+u_{1 t} & \text { (supply) } \\
p_{t}=c+d q_{t}+u_{2 t} & \text { (demand) }
\end{array}
$$

the current price has no effect on the current quantity supplied, and the model can be described by the chain:

lagged price $\rightarrow$ current quantity supplied $\rightarrow$ current price

Here it is reasonable to assume that the disturbance terms are independent of the explanatory variables, so that the method of least squares is suitable for estimation provided that other requirements for its use are fulfilled.

Putting together the functions derived for each stage of the pork and beef market structure, two basic multi-equation models can be written.

Model I:

$$
\begin{array}{ll}
\mathrm{X}_{\mathrm{p}} & =\mathrm{f}_{1}\left(\mathrm{Z}_{1}, \mathrm{Z}_{2}, \mathrm{Z}_{3}, \mathrm{~T}\right)+\mathrm{u}_{\mathrm{p}} \\
\mathrm{X}_{\mathrm{b}} & =\mathrm{f}_{2}\left(\mathrm{Z}_{4}, \mathrm{Z}_{5}, \mathrm{Z}_{6}, \mathrm{Z}_{7}, \mathrm{Z}_{8}, \mathrm{~T}\right)+\mathrm{u}_{\mathrm{b}} \\
\mathrm{Im}-\mathrm{Ex}_{\mathrm{p}} & =\mathrm{f}_{3}\left(\mathrm{P}_{\mathrm{pp}}\right)+\mathrm{u}_{\mathrm{imp}} \\
\mathrm{Im}-\mathrm{Ex}_{\mathrm{b}} & =\mathrm{f}_{4}\left(\mathrm{P}_{\mathrm{pb}}\right)+\mathrm{u}_{\mathrm{mb}} \\
\mathrm{C}_{\mathrm{p}} & \equiv \mathrm{X}_{\mathrm{p}}+\mathrm{Im}-\mathrm{Ex}_{\mathrm{p}} \\
\mathrm{C}_{\mathrm{b}} & \equiv \mathrm{X}_{\mathrm{b}}+\mathrm{Im}-\mathrm{Ex}_{\mathrm{b}} \\
\mathrm{P}_{\mathrm{pr}} & =\mathrm{f}_{7}\left(\mathrm{C}_{\mathrm{p}}, \mathrm{C}_{\mathrm{b}}, \mathrm{Y}\right)+\mathrm{u}_{\mathrm{pr}} \\
\mathrm{P}_{\mathrm{br}} & =\mathrm{f}_{8}\left(\mathrm{C}_{\mathrm{p}}, \mathrm{C}_{\mathrm{b}}, \mathrm{Y}\right)+\mathrm{u}_{\mathrm{br}} \\
\mathrm{M}_{\mathrm{p}} & =\mathrm{f}_{9}\left(\mathrm{~W}, \mathrm{P}_{\mathrm{pr}}, \mathrm{Im}-\mathrm{Ex}_{\mathrm{p}}\right)+\mathrm{u}_{\mathrm{mp}} \\
\mathrm{M}_{\mathrm{b}} & =\mathrm{f}_{10}\left(\mathrm{~W}, \mathrm{P}_{\mathrm{br}}, \mathrm{Im}-\mathrm{Ex}_{\mathrm{b}}\right)+\mathrm{u}_{\mathrm{mb}} \\
\mathrm{P}_{\mathrm{pp}} & \equiv \mathrm{P}_{\mathrm{pr}}-\mathrm{M}_{\mathrm{p}} \\
\mathrm{P}_{\mathrm{bp}} & \equiv \mathrm{P}_{\mathrm{br}}-\mathrm{M}_{\mathrm{b}}
\end{array}
$$

Model II is obtained from model I by replacing the Im-Ex functions (9.3) and (9.4) by the following functions:

$(9.13) \cdot \operatorname{Im}-\mathrm{Ex}_{\mathrm{p}}=\mathrm{f}_{13}\left(\mathrm{X}_{\mathrm{p}}, \mathrm{Y}\right)+\mathrm{u}_{\mathrm{imp}}^{\prime}$

(9.14) $\quad \operatorname{Im}-\mathrm{Ex}_{\mathrm{b}}=\mathrm{f}_{14}\left(\mathrm{X}_{\mathrm{b}}, \mathrm{Y}\right)+\mathrm{n}_{\mathrm{imb}}^{\prime}$

Explicit forms of the models will be given later on.

$5 \quad 8609-68$ 
According to the basic theory of multi-equation models, the dependent variables of the functions are endogenous, the other variables being predetermined. It is easily seen that model I is simultaneous and model II recursive. There are some implicit assumptions behind these conclusions. Therefore, we will examine the simultaneity of model I in greater detail and show that it can be considered as a block-recursive model which consists of three blocks, two blocks being formed by the supply functions and the third containing the rest of the model, the price formation part, i.e., the functions (9.3)-(9.12). To begin with, the following question can be raised regarding the simultaneity of supply and demand functions: Is the supply of the commodity in question affected by its current price. ${ }^{1}$ If the answer is in the affirmative, the system is simultaneous; i.e., we have to use a simultaneous model of demand and supply functions. This problem was already dealt with in Section 6.1, and the answer was in the negative. The quantity of pork supplied may respond to the current price in the short run, say, within a month; but when quarterly data are used for estimation, a delay in slaughterings cannot have much effect on the total quantity supplied. The effect is likely to be too slight to be verified statistically.

The situation is similar in the case of beef. Since beef is mainly a byproduct of milk production, feed supply will be the main factor determining the short run variations from a crop year to another in the quantity supplied. Thus, the current price may have little effect on the quantity supplied. Of course, the quantity of beef supplied may depend on the lagged price, but it does not make the demand and supply functions simultaneous, whatever the lag is.

As to the other explanatory variables in the supply functions, it can be concluded that they are determined by factors external to the model. The feed and potato prices included in the supply function for pork are determined by the corresponding crops, of which only a part goes to pork production; and thus the quantity of pork produced cannot have much effect on these prices, i.e., they may be regarded as predetermined. Hay yield in the supply function of beef is clearly a predetermined variable; and so is the number of cows in the short run, since it is actually a lagged variable. More than one equation might be employed to explain "beef production». Not only beef but also veal was included in it in the present study, and its composition may vary depending on the price and feed situations. Inventory models of dairy cows and calves, explaining the stocks of them, might also

1 We will here partly follow the procedure used by Fox in determining whether a single or multi-equation model has to be used from the estimation point of view. His way to approach the problem is, however, partly incomplete, since he deals only with simultaneous or single equation models, but pays no attention to recursive models. Fox, Karl A.: The Analysis of Demand for Farm Products. U.S. Dept. of Agr., Technical Bulletin No. 1081. Washington 1953, pp. 11—14. 
be useful, since the total beef and veal production depends on these. ${ }^{1}$ However, this was left to be done later, since it seemed to be difficult to form a complete model for that purpose in this connection.

The above considerations allow concluding that the causal relationship in the supply functions is unilateral: the quantity supplied has no effect on the explanatory variables. There are no common endogenous variables in the supply functions, either, which would cause these functions to form a part of a simultaneous model or to constitute a complete model on their own. If the supply function to be estimated includes only predetermined variables, the method of least squares is suitable for estimation, irrespective of the character of the multiequation model. ${ }^{2}$ Therefore, the parameters of the supply functions in our models can be estimated by that method.

We proceed to examine the price formation part of model I. The next question to be considered is this: Is the consumption of the commodities concerned significantly affected by their current prices or by the demand for exports, imports or storage? A negative answer would again imply a single equation model estimation, since production will then be equal to consumption and, since production is considered to be predetermined, the same applies to consumption. Hence, storage holdings and/or net imports need not be included in the demand function as separate variables. In a strict sense, however, net imports and changes in storage holdings should be zero in order for the answer to the question to be in the negative. This assumption is often relaxed: if net imports and changes in storage holdings are relatively small, compared with consumption, and if changes in consumption, storage holdings and net imports move in the same direction in response to changes in supply, the single equation method may give quite accurate estimates of demand flexibilities, because then the equality of production and consumption makes it reasonable to treat consumption as a predetermined variable. $^{3}$

The difficulty in defining the "relative smallness" is obvious. It is frequently evident that, as marginal factors, exports and imports have a substantial effect on price. Exports and imports of pork accounted for nearly 10 per cent of the total consumption of pork and beef during the sample period, and the figure for imports was even higher in some years. Thus it does not seem justified to answer the above question in the negative. Hence, we should have a multi-equation model of demand and foreign trade. The

I See, for example, Crom, Richard J. and Makr, Wilbur R.: A Dynamic Model of Simulated Livestock-Meat Economy. Agricultural Economics Research, U.S. Dept. of Agr., Vol. XVII, No. 3; July 1965, pp. 82-83.

2 Friedman, Joan and Foote, Richard J.: Computational Methods for Handling Systems of Simultaneous Equations. U.S. Dept. of Agr., Agriculture Handbook No. 94, November 1955, p. 55 .

3 Fox: op. cit., p. 13. 


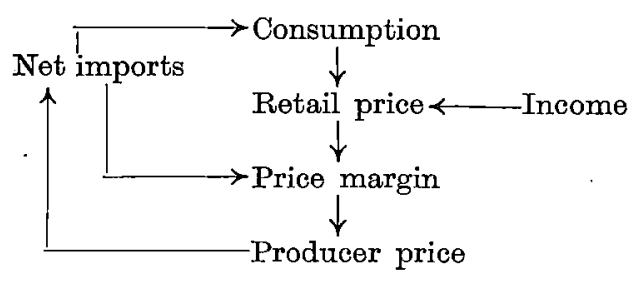

.Figure 9.1. The simultaneity of the demand and net imports functions.

situation may be similar as regards the storage holdings function, ${ }^{1}$ but the possibility of including such a function was ruled out, as already stated, by the lack of data.

The simultaneity of the demand and net imports functions in the model is perhaps clearest, in principle. If the actual producer price is outside the target price range, imports (or exports, depending on the situation) are to be permitted. But as was explained earlier, the quarterly data cannot reveal the price difference which caused the trade, since imports (exports) affect the producer price simultaneously through the demand and price margin functions, as the model suggests (see Figure 9.1). It may be argued that it is the purpose of the simultaneous approach to produce the difference before the estimation of the parameters of the Im-Ex functions is possible.

The third variable to be considered in the demand function is the disposable income. Does it depend on the consumption or the price of the commodity? According to general macroeconomic theory, income and consumption are determined simultaneously, i.e., they are interdependent. It is generally agreed, however, that in the case of a single commodity, income is only slightly affected by its consumption, which only forms a small proportion of total consumption. The effect of prices on consumers' income is, moreover, stabilized by the fact that the price elasticities of both pork and beef are close to unity, and thus the money expenditure on them is rather constant in the short run. ${ }^{2}$ Therefore it is reasonable to treat the disposable income as an independent variable. The inclusion of a function explaining the generation of income would also violate the character of the model, in the sense that it would be an aggregate function for the whole economy, whereas the other functions are sectoral.

The fourth point to be discussed relates to the homogeneity of the use of the commodity under consideration: Is more than one major domestic outlet available for the commodity? A negative answer would again imply

1 For example, Harnow has a model where the dependent variable is the cold storage holdings of pork, the explanatory variables being the quantity of pork produced, the cold storage holdings and deflated retail price of pork and the seasonal index, all lagged by one quarter. HARLOw: A Recursive Model ..., op. cit., p. 4.

2 Fox: op. cit., p. 13. 
a single equation model and method. Agricultural products are often consumed in different forms, fresh and processed, which are, however, to a certain extend substitutes of each other. Pork and beef clearly belong to this category: about $1 / 3$ of total pork and beef production is consumed in the form of processed meat, mainly as sausage, but also as canned and cooked meat products. The demand for these may be different from that for fresh meat. Therefore, we should have a multi-equation model for the demand for fresh and processed meat, since it is evident that the quantity of processed meat consumed affects the retail price of fresh meat. However, causation in the opposite direction is not as clear, since the retail price of sausage was controlled almost throughout the research period. Thus, it might even be legitimate to consider the retail price of sausage as a predetermined variable and to estimate for it an ordinary demand function with consumption as the dependent variable and retail price as the independent variable. Unfortunately, no quarterly data are available on the consumption of sausage, but only annual figures on production and raw material (meat) consumption. Nor are these figures complete for the beginning of the research period. Thus, such a theoretically more accurate model had to be abandoned. We only hope that collection of quarterly data. on sausage production will be started, since quite a good estimate of sausage consumption could also be obtained from them.

The lack of data on the consumption of processed meat can be compensated for at least to some extent through making use, for purposes of comparison, of the ordinary demand function and regarding consumption as the dependent variable and prices as the independent variables. The total domestic disappearance, as used in this study, is obviously the best measure for the total consumption of both fresh and processed meat; the amount of sausage produced (consumed) is not strictly comparable to the quantity of fresh meat consumed in sausage production, since raw materials other than meat are also used for it. The retail price of sausage can then be included in the (ordinary) demand function as an independent variable, in addition to the retail prices of pork and beef:

$$
C=f\left(P_{p r}, P_{s}, P_{b r}, Y\right)+u,
$$

where $P_{s}=$ retail price of sausage. The function is applicable to both products, i.e., $\mathrm{C}$ may be either $\mathrm{C}_{\mathrm{p}}$ or $\mathrm{C}_{\mathrm{b}}$. Interdependence of the retail prices for fresh and processed meat may, however, disturb the analysis. - This function is not included in any of the multi-equation models dealt with in the present study.

Let us then proceed to examine the price margin function of the model, involving $\mathrm{P}_{\mathrm{r}}, \mathrm{Im}-\mathrm{Ex}$ and $\mathrm{W}$ as the explanatory variables. The wage level 
of workers in retail trade is in the same position as the disposable income in the demand function, i.e., it may be considered as predetermined, independent of the margin. The price margin for meat is only a small fraction of the total price margin income of retail trade, and thus it obviously has only a small effect, if any, on wages. That the other explanatory variables in the price margin function are interdependent has already become evident. The net imports variable is, however, connected in a recursive fashion with the price margin, since the latter variable does not ap near in the importexport function. By contrast, the retail price variable in the price margin function is interrelated with the other variables through the identity of the producer price, and the producer price is included in the import-export function, which, in turn, is related to the demand function according to our model. This link will be reconsidered in the following Chapter 10, where matrix notation makes it perhaps easier to see the simultaneity of the models.

\section{Block-recursive model}

Even where a function such as the supply functions in our models contains only predetermined variables, the dependent variable is usually included as an endogenous variable in other functions and the predetermined variables are among as the predetermined variables of the whole model. ${ }^{1}$ They are needed, for example, at the first stage of the two-stage least squares method, to obtain the computed values of the endogenous explanatory variables necessary for the second stage. ${ }^{2}$ However, since the quantity supplied is more or less predetermined in character, as was concluded earlier, it seems to be reasonable to treat it as an independent, predetermined variable in the subsequent equations of the model. This actually makes model I a block-recursive model, two blocks consisting of the supply functions and the rest of the functions forming the third or the price formation part of the model. Regarding estimation this means that no attention need be given to the predetermined variables in the supply functions when the parameters of the simultaneous model are estimated. The number of predetermined variables for the estimation of the parameters of the price formation functions is reduced considerably, even though it would not be any problem from the estimation point of view in the entire model I.

The use of the block-recursive model has, however, another advantage also: the supply functions can be derived and the quantity of pork or beef supplied can be predicted in a number of different ways, whereas the si-

1 This requirement has to be relaxed if the number of predetermined variables become large (DUEsenberRy and Klein: op. cit., p. 26) or if the nature of the variable is undetermined like that of the time series $1,2,3, \ldots$ (Friedman and Foote: op. cit., p. 66).

2 See, for example, Johnston: op. cit., pp. $258-260$. 
multaneous or price formation part of the model is rather definitely determined in this study, the only modifications being those in the demand functions, the re-estimation of which is not laborious. If a supply function were changed, this would mean a change in the predetermined variables, and the whole model ought to be re-estimated. The block-recursive model saves us from this statistical difficulty, since the price formation system is independent of the determination of the quantity supplied.

\subsection{Simultaneous submodel}

The simultaneity of price formation part of model I becomes clearer if it is written in matrix form, to be referred to as model Ia. ${ }^{1}$

(Iò.1) $\quad \mathbf{B} \oplus$

$$
\begin{aligned}
& \mathbf{B} \oplus\left[\begin{array}{llllllllll}
1 & 0 & 0 & 0 & 0 & 0 & 0 & 0 & 1 & 0 \\
0 & 1 & 0 & 0 & 0 & 0 & 0 & 0 & 0 & 1 \\
1 & 0 & 1 & 0 & 0 & 0 & 0 & 0 & 0 & 0 \\
0 & 1 & 0 & 1 & 0 & 0 & 0 & 0 & 0 & 0 \\
0 & 0 & 1 & 1 & 1 & 0 & 0 & 0 & 0 & 0 \\
0 & 0 & 1 & 1 & 0 & 1 & 0 & 0 & 0 & 0 \\
1 & 0 & 0 & 0 & 1 & 0 & 1 & 0 & 0 & 0 \\
0 & 1 & 0 & 0 & 0 & 1 & 0 & 1 & 0 & 0 \\
0 & 0 & 0 & 0 & 1 & 0 & 1 & 0 & 1 & 0 \\
0 & 0 & 0 & 0 & 0 & 1 & 0 & 1 & 0 & 1
\end{array}\right] \times\left[\begin{array}{l}
I_{m--E x_{p}} \\
I_{m}-E_{b} \\
\mathrm{C}_{\mathrm{p}} \\
\mathrm{C}_{\mathrm{b}} \\
\mathrm{P}_{\mathrm{pr}} \\
\mathrm{P}_{\mathrm{br}} \\
\mathrm{M}_{\mathrm{p}} \\
\mathrm{M}_{\mathrm{b}} \\
\mathrm{P}_{\mathrm{pp}} \\
\mathrm{P}_{\mathrm{rb}}
\end{array}\right]+\mathbf{C} \oplus\left[\begin{array}{llll}
0 & 0 & 0 & 0 \\
0 & 0 & 0 & 0 \\
1 & 0 & 0 & 0 \\
0 & 1 & 0 & 0 \\
0 & 0 & 1 & 0 \\
0 & 0 & 1 & 0 \\
0 & 0 & 0 & 1 \\
0 & 0 & 0 & 1 \\
0 & 0 & 0 & 0 \\
0 & 0 & 0 & 0 \\
& &
\end{array}\right] \\
& \times\left[\begin{array}{c}
\mathrm{X}_{\mathrm{p}} \\
\mathrm{X}_{\mathrm{b}} \\
\mathrm{Y} \\
\mathrm{W}
\end{array}\right]+\left[\begin{array}{c}
\mathrm{a}_{1} \\
\mathrm{a}_{2} \\
0 \\
0 \\
\mathrm{a}_{5} \\
\mathrm{a}_{6} \\
\mathrm{a}_{7} \\
\mathrm{a}_{8} \\
0 \\
0
\end{array}\right]+\left[\begin{array}{c}
\mathrm{u}_{1} \\
\mathrm{u}_{2} \\
0 \\
0 \\
\mathrm{u}_{5} \\
\mathrm{u}_{6} \\
\mathrm{u}_{7} \\
\mathrm{u}_{8} \\
0 \\
0
\end{array}\right]=\left[\begin{array}{l}
0 \\
0 \\
0 \\
0 \\
0 \\
0 \\
0 \\
0 \\
0 \\
0
\end{array}\right]
\end{aligned}
$$

where $\mathbf{B}$ is the matrix of regression coefficients $b_{i j}$ (here $\left.i, j=1,2, \ldots, 10\right)^{-}$ of the endogenous variables, $\mathbf{C}$ being the matrix of regression coefficients $\mathrm{c}_{\mathrm{kl}}$ (here $\mathrm{k}=1,2, \ldots, 10$ and $\mathrm{l}=1,2,3,4$ ) of predetermined variables.

1 The operator $\oplus$ as used in this study is defined as follows: $\mathbf{A} \oplus \mathbf{B}$ is a matrix $\mathbf{C}$ whose elements are $\mathbf{c}_{1 \mathrm{j}}=\mathbf{a}_{\mathbf{1 j}} \mathbf{b}_{\mathrm{ij}}$. 
The endogenous variables in model III are Im- $\mathrm{Ex}_{\mathrm{p}}, \mathrm{Im}-\mathrm{Ex}_{\mathrm{b}}, \mathrm{C}_{\mathrm{p}}, \mathrm{C}_{\mathrm{b}}, \mathrm{P}_{\mathrm{pr}}$, $\mathrm{M}_{\mathrm{p}}, \mathrm{M}_{\mathrm{b}}, \mathrm{P}_{\mathrm{py}}$ and $\mathrm{P}_{\mathrm{bp}}$ and the predetermined variables are $\mathrm{X}_{\mathrm{p}}, \mathrm{X}_{\mathrm{b}}, \mathrm{Y}$ and $\mathrm{W}$. Since four of the equations are identities, to be eliminated before estimation, there are again six equations to be estimated.

According to the order condition ${ }^{1}$ all equations in model Ia are overidentified. If the production and import-export variables are used, instead of consumption, in the demand functions, the model $\mathrm{Ib}$

$$
\begin{aligned}
& \mathbf{B} \oplus\left[\begin{array}{llllllll}
1 & 0 & 0 & 0 & 0 & 0 & 1 & 0 \\
0 & 1 & 0 & 0 & 0 & 0 & 0 & 1 \\
1 & 1 & 1 & 0 & 0 & 0 & 0 & 0 \\
1 & 1 & 0 & 1 & 0 & 0 & 0 & 0 \\
1 & 0 & 1 & 0 & 1 & 0 & 0 & 0 \\
0 & 1 & 0 & 1 & 0 & 1 & 0 & 0 \\
0 & 0 & 1 & 0 & 1 & 0 & 1 & 0 \\
0 & 0 & 0 & 1 & 0 & 1 & 0 & 1
\end{array}\right] \times\left[\begin{array}{l}
\operatorname{Im}_{-E_{p}} \\
\operatorname{Im}_{\mathbf{p}}-E_{\mathrm{b}} \\
\mathrm{P}_{\mathrm{pr}} \\
\mathrm{P}_{\mathrm{br}} \\
\mathrm{M}_{\mathrm{p}} \\
\mathrm{M}_{\mathrm{b}} \\
\mathrm{P}_{\mathrm{pp}} \\
\mathrm{P}_{\mathrm{bb}}
\end{array}\right]+\mathbf{C} \oplus\left[\begin{array}{llll}
0 & 0 & 0 & 0 \\
0 & 0 & 0 & 0 \\
1 & 1 & 1 & 0 \\
1 & 1 & 1 & 0 \\
0 & 0 & 0 & 1 \\
0 & 0 & 0 & 1 \\
0 & 0 & 0 & 0 \\
0 & 0 & 0 & 0
\end{array}\right] \\
& \times\left[\begin{array}{c}
X_{p} \\
X_{b} \\
Y \\
W
\end{array}\right]+\left[\begin{array}{c}
a_{1} \\
a_{2} \\
a_{3} \\
a_{4} \\
a_{5} \\
a_{6} \\
a_{7} \\
a_{8}
\end{array}\right]+\left[\begin{array}{l}
u_{1} \\
u_{2} \\
u_{3} \\
u_{4} \\
u_{5} \\
u_{6} \\
0 \\
0
\end{array}\right]=0
\end{aligned}
$$

is not identified since the demand functions are now under-identified. Therefore, it is not possible to estimate the parameters of the model $\mathrm{Ib}$.

\section{Recursive model}

The matrix equation (10.1) clearly reveals that the only variables which make the model $I$ a simultaneous are $P_{p p}$ and $P_{b p}$. If we could get rid of the unities in the upper right corner of the first $1-0$ matrix in (10.2), the model would become a recursive one. To this end, the second of the alter-

1 An equation is identified if the number of the predetermined variables excluded from the equation to be estimated is at least equal to the number of the endogenous variables in the equation minus one. The order condition is only a necessary condition for identification. The necessary and sufficient condition for identification is the so called rank condition. See, for example, JoHNSTON, op. cit., pp. 250-251, or FISHER, Franklin M.: Identification Problem in Econometrics. New York 1966 , p. 40. 
native import-export functions, (6.9), was derived, with production and income as the explanatory variables. An argument in support of introducing these equations is that consumption is more stable than production and increases with the rising income. The variations in production have to be offset trough imports and exports.

The supply functions may be included in the recursive model II which is written below in matrix form in order to show the diagonality of the matrix of the coefficients of the endogenous variables:

$$
\mathbf{B Y}+\mathbf{C Z}+\mathbf{A}+\mathbf{u}=\mathbf{0}
$$

where

$$
\mathbf{B Y}=\mathbf{B} \oplus\left[\begin{array}{llllllllllll}
\mathrm{N} & 0 & 0 & 0 & 0 & 0 & 0 & 0 & 0 & 0 & 0 & 0 \\
0 & \mathbf{N} & 0 & 0 & 0 & 0 & 0 & 0 & 0 & 0 & 0 & 0 \\
1 & 0 & 1 & 0 & 0 & 0 & 0 & 0 & 0 & 0 & 0 & 0 \\
0 & 1 & 0 & 1 & 0 & 0 & 0 & 0 & 0 & 0 & 0 & 0 \\
1 & 0 & 1 & 0 & 1 & 0 & 0 & 0 & 0 & 0 & 0 & 0 \\
0 & 1 & 0 & 1 & 0 & 1 & 0 & 0 & 0 & 0 & 0 & 0 \\
0 & 0 & 0 & 0 & 1 & 1 & 1 & 0 & 0 & 0 & 0 & 0 \\
0 & 0 & 0 & 0 & 1 & 1 & 0 & 1 & 0 & 0 & 0 & 0 \\
0 & 0 & 1 & 0 & 0 & 0 & 1 & 0 & 1 & 0 & 0 & 0 \\
0 & 0 & 0 & 1 & 0 & 0 & 0 & 1 & 0 & 1 & 0 & 0 \\
0 & 0 & 0 & 0 & 0 & 0 & 1 & 0 & 1 & 0 & 1 & 0 \\
0 & 0 & 0 & 0 & 0 & 0 & 0 & 1 & 0 & 1 & 0 & 1 \\
& & & & & & & & & & &
\end{array}\right] \times\left[\begin{array}{l}
\mathrm{X}_{\mathrm{p}} \\
\mathrm{X}_{\mathrm{b}} \\
\mathrm{Im}-\operatorname{Ex}_{\mathrm{p}} \\
\mathrm{Im}-\mathbf{E x}_{\mathrm{b}} \\
\mathrm{C}_{\mathrm{p}} \\
\mathrm{C}_{\mathrm{b}} \\
\mathrm{P}_{\mathrm{pr}} \\
\mathrm{P}_{\mathrm{br}} \\
\mathrm{M}_{\mathrm{p}} \\
\mathrm{M}_{\mathrm{b}} \\
\mathrm{P}_{\mathrm{pp}} \\
\mathrm{P}_{\mathrm{bp}}
\end{array}\right]
$$

or, by using production and net imports instead of consumption in the demand functions (model IIa):

$$
\mathbf{B Y}=\mathbf{B} \oplus\left[\begin{array}{llllllllll}
\mathrm{N} & 0 & 0 & 0 & 0 & 0 & 0 & 0 & 0 & 0 \\
0 & N & 0 & 0 & 0 & 0 & 0 & 0 & 0 & 0 \\
1 & 0 & 1 & 0 & 0 & 0 & 0 & 0 & 0 & 0 \\
0 & 1 & 0 & 1 & 0 & 0 & 0 & 0 & 0 & 0 \\
1 & 1 & 1 & 1 & 1 & 0 & 0 & 0 & 0 & 0 \\
1 & 1 & 1 & 1 & 0 & 1 & 0 & 0 & 0 & 0 \\
0 & 0 & 1 & 0 & 1 & 0 & 1 & 0 & 0 & 0 \\
0 & 0 & 0 & 1 & 0 & 1 & 0 & 1 & 0 & 0 \\
0 & 0 & 0 & 0 & 1 & 0 & 1 & 0 & 1 & 0 \\
0 & 0 & 0 & 0 & 0 & 1 & 0 & 1 & 0 & 1 \\
0 & & & & & & & &
\end{array}\right] \times\left[\begin{array}{l}
\mathbf{X}_{\mathrm{p}} \\
\mathbf{X}_{\mathrm{b}} \\
\mathrm{Im}-\mathbf{E x}_{\mathrm{b}} \\
\mathrm{Im}-\mathbf{E x}_{\mathrm{p}} \\
\mathrm{P}_{\mathrm{pr}} \\
\mathrm{P}_{\mathrm{br}} \\
\mathrm{M}_{\mathrm{p}} \\
\mathrm{M}_{\mathrm{b}} \\
\mathrm{P}_{\mathrm{pp}} \\
\mathrm{P}_{\mathrm{bp}}
\end{array}\right]
$$




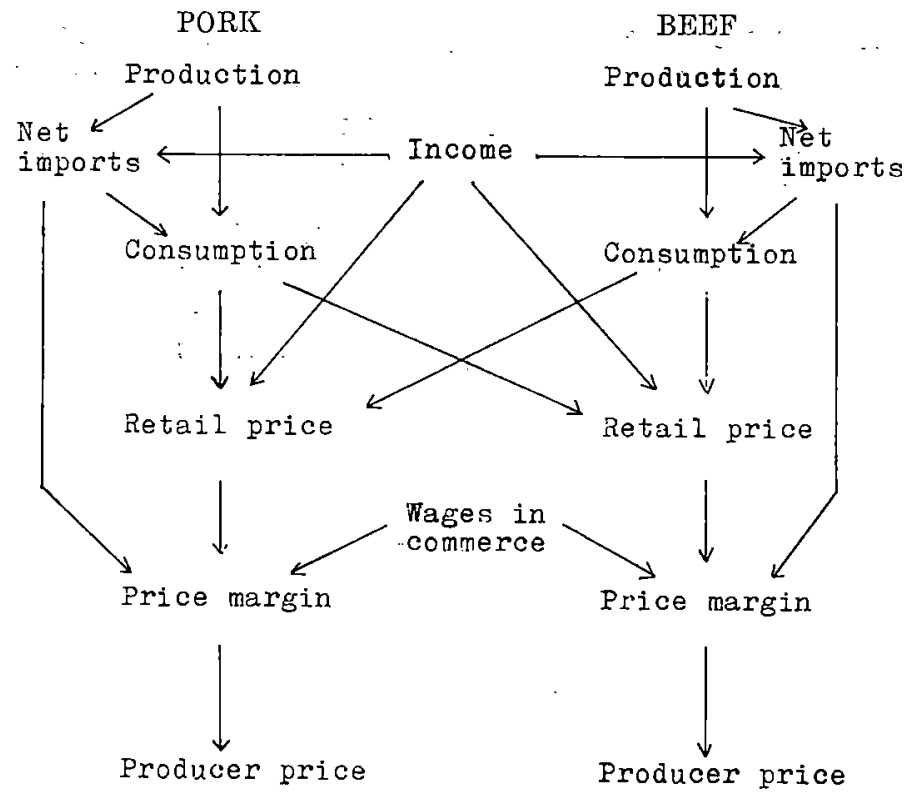

Figure 11.1 The recursive model II a.

The matrices CZ, $\mathbf{A}$ and $\mathbf{u}$ are not presented here, since they do not affect the character of the model in any way. The entire model II is given in explicit form in Chapter 13. Model IIa is also illustrated in Figure 11.1.

Now, a theoretical problem has to be solved in order to justify the use of the least-squares method in the estimation of the parameters. The problem arises from the requirement that the value of the determinant of the coefficients of the endogenous variables be equal to one (or a constant). ${ }^{1}$ However, the supply functions are estimated on a total quantity basis, whereas the other functions rest on a per capita basis. This is why the first two diagonal elements are $\mathrm{Ns}$, as the quantity variables are measured on a per capita basis. Since all elements above the diagonal are zeros, the value of the determinant equals the product of the diagonal elements, or $\mathrm{N}^{2}$. However, $\mathbf{N}$ is a variable, and thus the determinant is not constant. To justify the use of the model we may either (a) keep $\mathrm{N}$ constant, which is legitimate considering that the variations in it are rather small and regular or (b) confine ourselves to the same part of the total model as in the case of the simultaneous model, i.e., we may drop the first two equations, after which the remaining model only includes quantity variables expressed on a per

1 This condition refers to the likelihood function where the determinant [B] appears as a constant. If it is not constant, the maximization of the likelihood function becomes complicated. See, for example, Koopmans and Hood, op. cit., pp. 145-149. 
capita basis. Since the ordinary least squares method is applied in the estimation, no practical difficulties will be met in the estimation, even though the mathematical condition were not fulfilled for the entire model.

The situation is similar with respect to prices, which are deflated by the producer price index in the supply functions and by the cost of living index in the other functions. However, the matrix BY includes only the cost of living index as a deflator, and thus all price variables are homogenous in that sense. In general, it is the linearity of the model that makes it possible to solve it for the endogenous variables, i.e., to derive the reduced form as described earlier. Since the deflators do not appear explicitly as variables, the deflated prices are usually considered, just as in the present study, as separate variables. ${ }^{1}$ This seems also legitimate considering that the theory behind the formulation of the structural equations assumes the value of money to be constant, and this is achieved only by deflation. Deflation may also help: to achieve the homoscedasticity of the variables, meaning that the variance of the variables is constant through time, which is one of the basic assumptions of all estimation methods. ${ }^{2}$ It may, however, be badly violated by inflation.

When the import-export functions were derived in Section 6.5, it was considered questionable whether it is possible to have any function for the foreign trade at all, since the trade is not free and trade commitments make the Im-Ex variable predetermined to some extent. If the import-export equations are dropped from the model, the remaining model, where importsexports is a predetermined variable, will always be recursive. This modification, called model III, needs no extra estimation if the least squares method is suitable for the recursive model II. This modification is a convenient way to employ the empirical results for practical purposes.

1 Friedman and Foote: op. cit., p. 66.

2 Johnston: op. cit., pp. $7-9$. 


\section{ESTIMATES OF THE PARAMETERS}

Before presenting the results of estimation, the elimination of seasonal variations will be discussed, and a short description will be given of the various estimates presented in the following tables and in the text, in order to make their interpretation easier. After that, the least-squares estimates of the coefficients of the supply functions will be discussed. They are best linear unbiased estimates, and thus it is unnecessary to employ any other estimation method. Secondly, the least squares estimates of parameters for the recursive model II are presented. The correlation matrix of the residuals of the total recursive model is calculated, to check whether the assumption of non-correlation of disturbances is valid. Thirdly, the two-stage least squares estimates of the simultaneous model I aare presented and evaluated. The fit of the primary functions is illustrated graphically and the estimates yielded by different methods are compared.

\section{Elimination of seasonal variation}

In the elimination of seasonal variations the dummy variable method was applied in such a way that the following variables were included in the quarterly functions:

$\mathrm{D}_{\mathrm{II}}=1$ in the second quarter, otherwise 0

$\mathrm{D}_{\mathrm{III}}=1$ in the third quarter, otherwise 0

$D_{I V}=1$ in the fourth quarter, otherwise 0 ,

and in the semiannual functions:

$\mathrm{D}_{2}=1$ in the second half of the year (July-December), otherwise 0.

Although the loss of the degrees of freedom was 3 when the method was applied to quarterly models, it would have been even greater had the traditional method of elimination of the seasonal variation been employed, by first computing the index of seasonal variation and then dividing the original observations by it. ${ }^{1}$

1 Loveld, Michale C.: Seasonal Adjustment of Economic Time Series and Multiple Regression Analysis. Journal of the American Statistical Association, Vol. 58, No. 304, pp. 993-1010. 
To simplify the matrix notation , f the models, the seasonal dummy variables were not included in the previous functions, since they are predetermined variables and have no influence on the character of the models.

\section{Different estimates of parameters and statistical tests}

Conventional formulas were applied to compute the regression coefficients (b), their standard errors $\left(s_{b}\right)$ and Student's t-values. The 95 per cent confidence level was considered to be the lowest acceptable for the estimates; nevertheless, estimates of all the coefficients which were included on an a priori basis in the functions will be presented.

The coefficient of multiple determination, $\mathrm{R}^{2}$, and the standard deviation of the residuals, $s_{1}$, give a general picture of the ability of each function to explain the variations in the dependent variable.

The intercept value of each function is denoted by a.

The Durbin-Watson statistic ${ }^{1}$

$$
d=\frac{\sum_{t=2}^{n}\left(u_{t}-u_{t-1}\right)^{2}}{\sum_{t=1}^{n} u_{t}{ }^{2}}
$$

was. computed to test whether the residuals are serially correlated. ${ }^{2}$ If they are, the standard errors of the coefficients computed by using the usual formula are not valid, although the regression coefficients are unbiased. ${ }^{3}$ The test is not very powerful, since it has a considerable range of indeterminacy.

To facilitate the interpretation of the coefficients, they have been transformed into flexibilities and elasticities, $b_{i}^{*}$, by using the formula

$$
b_{\mathrm{i}}^{*}=\frac{\overline{\mathrm{X}}_{\mathrm{i}}}{\overline{\bar{Y}}} \mathrm{~b}_{\mathrm{i}},
$$

where $\bar{X}_{i}$ is the arithmetic mean of the explanatory variable (either exogenous or endogenous); $b_{i}$, the corresponding regression coefficient; and $\bar{Y}$, the

1. Durkin, J. and Watson, G. S.: Testing for Serial Correlation in Leasts Squares Regression, pts. I and II, Biometrica, 1950 and 1951.

2 The use of the terms sserial correlation" and sautocorrelation» in the case of residuals has been somewhat inconsistent. For example, WoLd and TINTNER use the term autocorrelation, whereas MaLinvaud, Jonnston and GoLDBerger speak about serial correlation, which seems. to be more common usage.

3 See, Johnston, op. cit. pp. 188-189 or Wold, Herman and JuReen, Lars: Demand Analysis. Uppsala 1952, pp. 210-211 and p. 235. The error made when the residuals are serially correlated depends on how the residuals are related to each other. WOLD and JoHNston, for example, assume them to follow a first-order Markov scheme. 
arithmetic mean of the dependent variable of the function under consideration. ${ }^{1}$

It is not reasonable to compute an elasticity for the import-export. variable, since its mean value is close to zero, and thus the elasticity would also be close to zero.

Neither were the regression coefficient of the time variable $T$ transformed into any elasticity, since this would not have been meaningful. As such it gives a linear trend for a quarter or half-year. No elasticities are meaningful for the 0-1 dummy variables, either.

The last column of each table gives the loss of the sum of explained squares of the dependent variable resulting if the explanatory variable is deleted from the function. It can be computed as follows: ${ }^{2}$

$$
\text { Loss of } \mathrm{SS}_{\mathrm{y}}=\frac{\mathrm{b}_{\mathrm{i}}^{2}}{\mathrm{t}^{\mathrm{ii}}}
$$

where $t^{\text {ii }}$ is the diagonal element of the inverse matrix of the explanatory variables. The loss of sum of squares gives an idea of the importance of the variables from the point of view of the degree of explanation, if it is compared with the total sum of squares of the dependent variable, $\mathrm{SS}_{\mathrm{y}}$, given in the tables.

This loss of sum of squares was employed in examining the effect of the multicollinearity of the variables on the estimates and their standard errors. Theoretically, the estimates are unbiased, even though there were some intercorrelation among the variables, but the standard errors easily become large. ${ }^{3}$ Not only the coefficients of correlation between the explanatory variables (given in Appendix II) but also the size of standard errors can be used as an indication of multicollinearity. Especially, if variables are added into the function successively, the change in size of the standard errors, and also of the estimates of regression coefficients, may give valuable information about multicollinearity. ${ }^{*}$ The following stepwise method was applied in this study: first, a function with all a priori variables was estimated; then the variable for which the loss of sum of squares was smallest, i.e., which was the least significant variable, was deleted from the function. This was repeated until there was only one variable left in the function, except the seasonal dummy variables, which were always retained in the functions.

1 The standard errors of the elasticities were not computed for all functions, since elasticities are not suitable for a more exact application of the estimated function, but the estimated functions themseles have to be applied. There are also difficulties in computing the standard errors of elasticities. See Schultz, Henry: The Theory and Measurement of Demand. Chicago 1958, pp. 767-775.

2 Willtams, E. J.: Regression Analysis. New York 1959, p. 35.

3 THIEL, H.: Eiconomic Forecasts and Policy. Contributions to Economic Analysis XV. Amster$\operatorname{dam} 1965$, p. 355 .

${ }^{4}$ KLeIN, Lawrence R.: An Introduction to Econometrics. Englewood Cliffs, 1965, p. 101. 
Statistical tests are aimed at examination of the properties of the estimates. However, even though the estimates were good a priori, in terms of tests, the data available for estimation may make the estimates unsatisfactory. The accuracy of the estimates depends, namely, on the size of the variance of the residuals, the range of observation of the variables, and on the number of the degrees of freedom. ${ }^{1}$ Variation of the observations up and down would also be desirable, so that the application of the estimates could be applied more confidently in both directions. Economic time series often include a rising trend, which may disturb the statistical analysis. For example, the multicollinearity of the explanatory variables then becomes a problem.

In the present study multicollinearity was avoided almost completely by deflation (see Appendix II). As to the range of the observations, the estimates of the import-export function for beef is obviously not very reliable, since at the beginning of the sample period there were no imports or exports. Variation in the deflated price margins was also rather small, and therefore it was to be expected that the results for the price margin functions would be rather poor.

Throughout the empirical part of the study, the elasticity estimates rather than the regression coefficients will be discussed. For the interpretation of the regression coefficients, see Appendix I, where the units of measuremetn are given. The base for the wage indices used in the study is 1.0.

\section{Supply functions}

\subsection{Supply functions for pork}

The estimates of the coefficients of the supply function involving the total quantity of pork produced as the dependent variable are given in Table.14.1. These estimates will subsequently be referred to as the function (14.1).

The elasticity estimates obtained are logical regarding not only their sign but also their size, and they are in accordance with the estimates obtained by KAARLEHTO for the sample period 1952-56, even though the elasticity with respect to the lagged producer price of pork $(0.204)$ is smaller than that in KAARLEHTO's study (0.401). The elasticity with respect to the feed price was about the same in both studies $(-0.559$ and- -0.571 , respectively). ${ }^{2}$

1 PöYhöNEn, Pentti: Ekonometria. In WARTS, Heikki and others (eds.): Yhteiskuntatieteiden käsikirja I. Keuruu 1963, p. 106.

2 KAARLEhto: Sianlihan markkinoinnista ..., op. cit., p. 23. 
Table 14.1. The supply of pork. A linear quarterly model, the total quantity of pork produced as the dependent variable

\begin{tabular}{|c|c|c|c|c|c|}
\hline $\begin{array}{c}\text { Explanatory } \\
\text { variable }\end{array}$ & $\begin{array}{l}\text { Reg. } \\
\text { coeff. } \\
\text { b }\end{array}$ & $\begin{array}{c}\text { Stand. } \\
\text { error } \\
\mathrm{s}_{b}\end{array}$ & $\underset{t}{\text { Student's }}$ & $\begin{array}{c}\text { Elasti- } \\
\text { city } \\
b^{*}\end{array}$ & $\begin{array}{l}\text { Loss of } \\
\text { sum of } \\
\text { squares }\end{array}$ \\
\hline 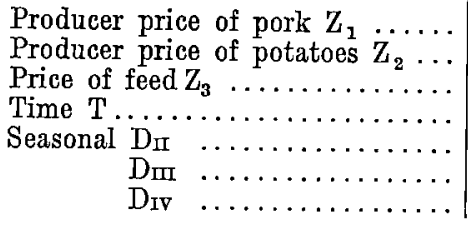 & $\begin{array}{r}1.399 \\
-0.090 \\
-0.357 \\
0.054 \\
0.494 \\
3.363 \\
5.194\end{array}$ & $\begin{array}{l}0.936 \\
0.048 \\
0.078 \\
0.013 \\
0.411 \\
0.432 \\
0.432\end{array}$ & $\begin{array}{r}1.49 \\
1.87 \\
4.60 \\
4.29 \\
1.20 \\
7.79 \\
12.02\end{array}$ & $\begin{array}{r}0.204 \\
-0.066 \\
-0.559 \\
- \\
- \\
-\end{array}$ & $\begin{array}{r}1.68 \\
2.63 \\
15.90 \\
13.86 \\
1.08 \\
45.56 \\
108.63\end{array}$ \\
\hline
\end{tabular}

$\mathrm{R}^{2}=0.890 \mathrm{~s}_{\mathrm{u}}=0.867 \mathrm{~d}=0.890 \mathrm{a}=19.35 \mathrm{SS}_{\mathrm{y}}=217.92$

The estimates are not, however, strictly comparable, since the dependent variable of KAARLEHTO's model was the quantity of pork marketed. When that model was applied, the estimates given in Table 14.2 were obtained (function (14.2)).

The price elasticities of the two models (14.1) and (14.2) did not differ noticeably from each other. Only the coefficients for time were different; in the case of the model (14.2) the time variable reflected the increase in the marketed quantity due to the decrease in the slaughterings on farms. The coefficient of multiple determination was higher for (14.1) than for (14.2). Therefore, a closer examination of the estimates of the function (14.1) is called for.

Of the structural coefficients, only those for feed price and time are statistically different from zero, at least at the 5 per cent confidence level. And the producer price for pork, which is of greatest interest for price policy purposes, is, in that sense, the least significant. This is also confirmed by the loss of sum of squares column, according to which, if we neglect for a

Table 14.2. The supply of pork. A linear quarterly model, the quantity of pork marketed as the dependent variable

\begin{tabular}{|c|c|c|c|c|c|}
\hline $\begin{array}{c}\text { Explanatory } \\
\text { variable }\end{array}$ & $\begin{array}{l}\text { Reg. } \\
\text { coeff. } \\
\text { b }\end{array}$ & $\begin{array}{l}\text { Stand. } \\
\text { error } \\
\mathrm{s}_{\mathrm{b}}\end{array}$ & $\underset{t}{\text { Student's }}$ & $\begin{array}{c}\text { Elasti- } \\
\text { city } \\
b^{*}\end{array}$ & $\begin{array}{l}\text { Loss of } \\
\text { sum of } \\
\text { squares }\end{array}$ \\
\hline 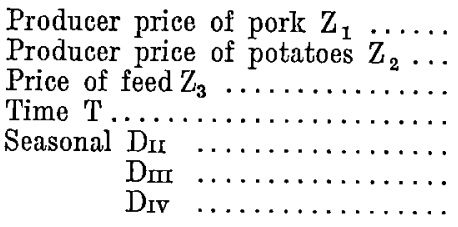 & $\begin{array}{r}1.339 \\
-0.034 \\
-0.312 \\
0.120 \\
0.239 \\
0.853 \\
2.626\end{array}$ & $\begin{array}{l}0.939 \\
0.048 \\
0.078 \\
0.013 \\
0.413 \\
0.433 \\
0.433\end{array}$ & $\begin{array}{l}1.42 \\
0.70 \\
4.01 \\
9.51 \\
0.58 \\
1.97 \\
6.06\end{array}$ & $\begin{array}{r}0.253 \\
-0.032 \\
-0.632 \\
- \\
- \\
-\end{array}$ & $\begin{array}{r}1.54 \\
0.37 \\
12.18 \\
68.43 \\
0.25 \\
2.93 \\
27.77\end{array}$ \\
\hline
\end{tabular}

$\mathrm{R}^{2}=0.842 \mathrm{~s}_{\mathrm{u}}=0.870 \mathrm{~d}=0.962 \mathrm{a}=14.07 \mathrm{SS}_{\mathrm{y}}=153.50$ 


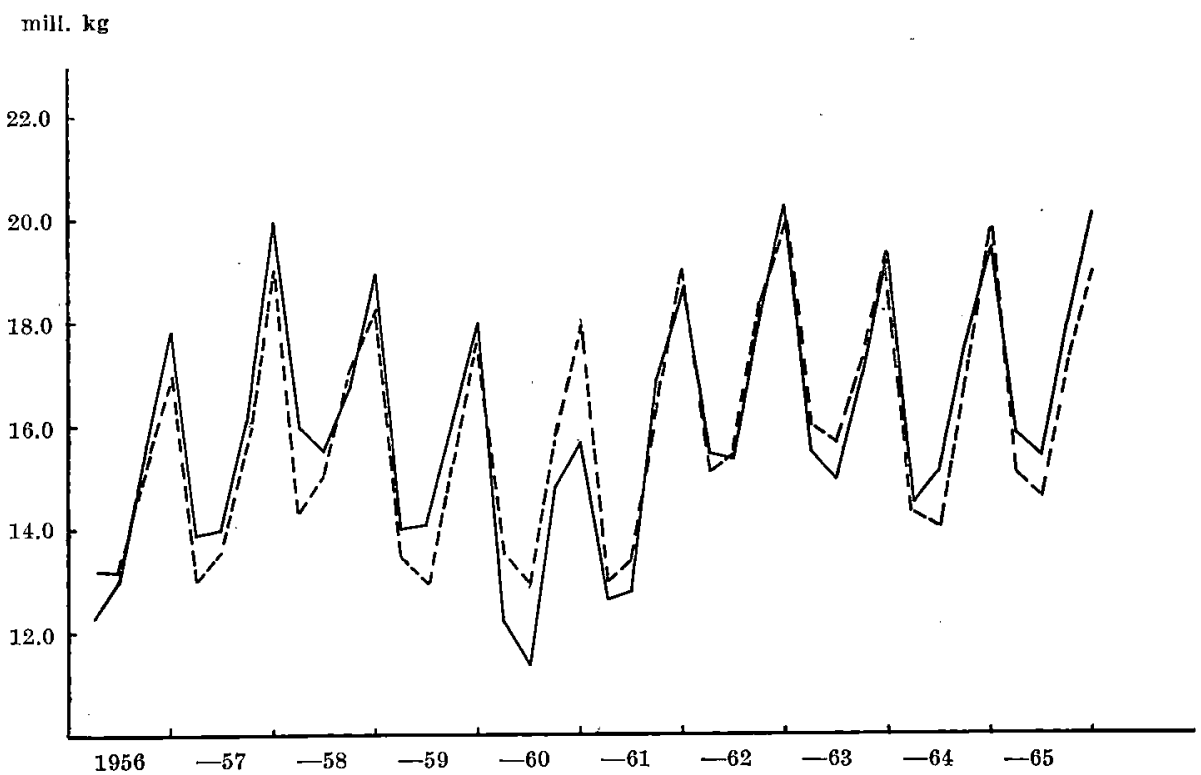

Figure 14.1. The observed values (corresponding values (- - - ) as estimated from function (14.1).

moment the seasonal dummy variables, feed price is the most important factor in the supply function, even though time is about as important. The seasonal dummy variables $\mathrm{D}_{\mathrm{III}}$ and $\mathrm{D}_{\mathrm{IV}}$ explain, however, most of the variation in the quantity of pork supplied. As can be seen from the coefficients of the dummy variables, the seasonal variation is rather large. For example, the quantity supplied is about 5.2 mill. $\mathrm{kg}$ higher in the fourth quarter and 3.4 mill. $\mathrm{kg}$ higher in the third quarter than in the first quarter. The corresponding regression coefficients are also very significant statistically (99.9 per cent confidence level).

As was stated previously, it is not meaningful to compute any elasticity for the time variable. The regression coefficient directly tells that the average trend, ceteris paribus, is about 0.054 mill. $\mathrm{kg}$ a quarter.

The Durbin-Watson statistic, $d=0.89$, indicates that the computed residuals are positively correlated with each other. This violates the assumption of non-correlation of disturbances. A look at Figure 14.1 reveals that a considerable part of the positive serial correlation is generated by the residuals for 1960 when pork production fell sharply. The reason for this decrease is not known, and therefore a $1-0$ dummy variable $\mathbf{D}_{3}$, obtaining the value on ein all quarters of 1960 and otherwise 0 , was introduced into the function:

$7 \quad 8609-68$ 


$$
\begin{gathered}
\mathrm{X}_{\mathrm{p}}=19.5+0.229 \mathrm{Z}_{1}-0.118 \mathrm{Z}_{2}-0.223 \mathrm{Z}_{3}+0.044 \mathrm{~T}-2.162 \mathrm{D}_{3} \\
(0.671)(0.033)(0.058) \quad(0.009) \quad(0.356) \\
+0.49 \mathrm{D}_{\mathrm{II}}+3.17 \mathrm{D}_{\mathrm{III}}+5.17 \mathrm{D}_{\mathrm{IV}}+\mathrm{u}_{\mathrm{p}} \\
(0.283) \quad(0.298) \quad(0.397) \\
\mathrm{R}^{2}=0.950 \mathrm{~s}_{\mathrm{u}}=0.595 \mathrm{~d}=1.22
\end{gathered}
$$

The coefficient of multiple determination rose to 0.95 and the Durbin-Watson statistic to 1.22 , which is, however, still inconclusive at the 5 per cent level. The coefficients for pork and feed prices were reduced considerably, which implies that the reason for the decrease in the production of pork in 1960 was reflected at least partly by the variables already in the function (14.1). Thus it is obviously preferable to use the function (14.1) for predictions, for example.

The estimates obtained through the stepwise method used to examine multicollinearity are given in Table 14.3. They are listed in an order reversed to that in computation. To facilitate interpretation, the elasticities are given instead of the regression coefficients, except for the time variable.

Since the elasticity estimates and the corresponding standard errors seem to be rather stable from one step to the next, it can be concluded that the multicollinearity of the variables did not disturb the estimation of the parameters.

Two attempts to modify the supply function for pork are still to be mentioned. The current producer price of pork was included in the function (14.1) to estimate the short run price elasticity; but its coefficient was negative, which only reflects the dependence of the current price on the quantity supplied.

Also, an attempt was made to estimate the long run price elasticities of

\begin{tabular}{|c|c|c|c|c|c|c|c|c|c|}
\hline \multirow{2}{*}{$\begin{array}{l}\text { Step } \\
\text { No. }\end{array}$} & \multirow{2}{*}{$R^{2}$} & & \multicolumn{3}{|c|}{ Seasonal dummy variables } & \multirow{2}{*}{$\begin{array}{c}\text { Elasti= } \\
\text { city w.r.t. } \\
\text { feed } \\
\text { price } \\
Z_{3}\end{array}$} & \multirow{2}{*}{$\begin{array}{c}\text { Reg. } \\
\text { ceeff. } \\
\text { of } \\
\text { time } \\
\mathrm{T}\end{array}$} & \multirow{2}{*}{$\begin{array}{c}\text { Elasti- } \\
\text { city w.r.t. } \\
\text { potato } \\
\text { price } \\
Z_{2}\end{array}$} & \multirow{2}{*}{$\begin{array}{c}\text { Elasti- } \\
\text { city w.r.t. } \\
\text { pork } \\
\text { price } \\
Z_{1}\end{array}$} \\
\hline & & & $\mathrm{D}_{\mathrm{II}}$ & $\mathbf{D}_{\mathrm{III}}$ & $\mathrm{D}_{\mathrm{IV}}$ & & & & \\
\hline 1. & 0.797 & 0.52 & & & & & - & - & - \\
\hline 2. & 0.872 & 0.81 & & 3.0 & $\begin{array}{r}4.7 \\
60.4\end{array}$ & $\begin{array}{r}-0.606 \\
(0.124)\end{array}$ & $\begin{array}{c}0.056 \\
(0.012)\end{array}$ & - & $\dot{-}$ \\
\hline & 0.882 & 0.82 & $\begin{array}{c}0.478 \\
(0.419)\end{array}$ & $\begin{array}{c}3.409 \\
(0.427)\end{array}$ & $\begin{array}{c}5.4073 \\
(0.432)\end{array}$ & $\begin{array}{c}-0.567 \\
(0.124)\end{array}$ & $\begin{array}{c}(0.051) \\
0.051 \\
(0.012)\end{array}$ & $\begin{array}{r}-0.056 \\
(0.035)\end{array}$ & \\
\hline & 0.890 & 0.89 & $\begin{array}{c}0.494 \\
(0.411)\end{array}$ & $\begin{array}{c}3.363 \\
(0.432)\end{array}$ & $\begin{array}{c}5.194 \\
(0.432)\end{array}$ & $\begin{array}{c}-0.559 \\
(0.121)\end{array}$ & $\begin{array}{c}0.054 \\
(0.013)\end{array}$ & $\begin{array}{r}-0.066 \\
(0.035)\end{array}$ & $\begin{array}{r}0.204 \\
(0.137)\end{array}$ \\
\hline
\end{tabular}
supply by using a Nerlove-type function where one of the explanatory

Table 14.3. The total supply of pork. The stepwise method. A linear quarterly model, the total quantity of pork produced as the dependent variable.

The standard errors are given in parentheses 
Table 14.4. The supply of pork. A linear semiannual model, the total quantity of pork produced as the dependent variable

\begin{tabular}{|c|c|c|c|c|c|}
\hline $\begin{array}{c}\text { Explanatory } \\
\text { variable }\end{array}$ & $\begin{array}{c}\text { Reg. } \\
\text { coeff. } \\
\text { b }\end{array}$ & $\begin{array}{l}\text { Stand. } \\
\text { error } \\
\mathbf{s}_{\mathbf{b}}\end{array}$ & $\underset{t}{\text { Student's }}$ & $\begin{array}{c}\text { Elasti- } \\
\text { city } \\
b^{*}\end{array}$ & $\begin{array}{l}\text { Loss of } \\
\text { sum of } \\
\text { squares }\end{array}$ \\
\hline Producer price of pork $\mathrm{Z}_{1} \ldots$ & 3.503 & 2.950 & 1.19 & 0.257 & 3.90 \\
\hline Producer price of potatoes $\ddot{\mathrm{Z}}_{2}$ & -1.389 & 1.389 & 1.00 & -0.051 & 2.77 \\
\hline Price of feed $Z_{3} \ldots \ldots \ldots \ldots$ & -7.730 & 2.191 & 3.53 & -0.606 & 34.45 \\
\hline Time $T \ldots \ldots \ldots \ldots \ldots$ & 0.218 & 0.069 & 3.16 & - & 27.59 \\
\hline Seasonal $\mathrm{D}_{2} \ldots \ldots \ldots$ & 8.296 & 0.837 & 9.91 & - & 271.73 \\
\hline
\end{tabular}

$\mathrm{R}^{2}=0.901 \mathrm{~S}_{\mathrm{u}}=1.664 \mathrm{~d}=1.268 \mathrm{a}=38.25 \mathrm{SS}_{\mathrm{y}}=391.68$

variables was the lagged quantity of pork $\left(\mathrm{X}_{\mathrm{pt}-5}\right) .^{1}$ The result was not, however, satisfactory, in that the estimate of the regression coefficient for the lagged quantity of pork supplied was not statistically significant and equaled only 0.08 . It means that the factor $\gamma$, by which all short run elasticities have to be divided in order to get the long run elasticities, is 0.92 , and thus the two types of elasticities are about the same. The Nerlove model assumes that the adjustment time necessary to reach equilibrium is the same for each variable. This restriction may be one of the reasons why poor results were obtained through the simple Nerlove model. It should be mentioned that MARTIN has developed a more complicated model, where the adjustment time is different for each variable. ${ }^{2}$ To apply such a model would, however, be a separate research object.

Since the quarterly data on total pork production were not accurate, owing to the lack of quarterly data on slaughterings on farms (only semiannual data were available), s e $m$ i a $n n u$ a $l$ models were estimated to examine whether the estimates of the quarterly model were systematically biased, which should manifest itself as differences between the estimates. These semiannual models may also be used for practical purposes, such as prediction. The estimates are given in Table 14.4.

The elasticities of the function (14.4) are only slightly different from the corresponding elasticities in (14.1). Even though the Durbin-Watson statistic, $\mathrm{d}=1.268$, is greater here than in (14.1), the test is still inconclusive. By employing the dummy variable $\mathrm{D}_{4}$ corresponding to $\mathrm{D}_{3}$ in the quarterly

1 The Nerlove model may be written in a concise form as follows:

$$
\mathrm{X}_{\mathrm{pt}}=\mathrm{a}^{\prime}+\gamma \mathrm{b}_{1} \mathrm{P}_{\mathrm{pt}-5}+\ldots+(1-\gamma) \mathrm{X}_{\mathrm{pt}-5}+\mathrm{u} .
$$

The parameters are estimated by the method of least squares and the adjustment coefficient $\gamma$ is computed from the regression coefficient of the lagged quantity. The long run elasticities are obtained by dividing each coefficient by $\gamma$. See, for example, NERLove, Marc: Distributed Lags and Estimation of Long-run Supply and Demand Elasticities: Theoretical Considerations. Journal of Farm Economics, Vol. 40, No. 2, May 1958, p. 309.

2 MaRTin, James E.: Isolation of Lagged Economic Responses. Journal of Farm Economics, Vol. 49, No. 1, Part I, February 1967, pp. 160-168. 
model, equal to one in 1960 and otherwise 0 , the following function was estimated:

$$
\begin{array}{r}
\mathrm{X}_{\mathrm{p}}=40.1+0.418 \mathrm{Z}_{1}-1.90 \mathrm{Z}_{2}-4.95 \mathrm{Z}_{3}-4.09 \mathrm{D}_{4}+0.172 \mathrm{~T}+8.01 \mathrm{D}_{2}+\mathrm{u}_{\mathrm{p}} \\
(2.14) \quad(0.95)(1.64) \quad(0.97) \quad(0.048) \quad(0.57) \\
\mathrm{R}^{2}=0.957 \mathrm{~s}_{\mathrm{u}}=1.133 \mathrm{~d}=1.589
\end{array}
$$

The test of serial correlation is still inconclusive, for the range of indeterminacy of the test is rather large for a small number of degrees of freedom. As in the case of the quarterly model, the elasticity with respect to the producer price of pork and the feed price fell considerably, to 0.031 and -0.388 respectively.

It can thus be concluded that the function (14.1) seems to provide a good basis for a comparison of the estimated functions with respect to their suitability for predicting pork production. Although the coefficient of multiple determination for the semiannual model is slightly higher, compared with the quarterly model, the standard deviation of the residuals is twice as large as in (14.1). Therefore, if the prediction of the semiannual model is estimated for the various quarters according to the index of seasonal variation, the prediction error can be expected to be about the same as that for the quarterly model.

\subsection{Supply functions for beef}

When all the variables, which were thought to belong to the supply function for beef, were included in the function to be estimated, the estimates given in Table 14.5 (function (14.5)) were obtained.

The estimates of the coefficients of the hay yield, number of cows and time variables are statistically significant according to the t-values. These

\begin{tabular}{|c|c|c|c|c|c|}
\hline$=\quad, \quad \begin{array}{c}\text { Explanatory } \\
\text { variable }\end{array}$ & $\begin{array}{l}\text { Reg. } \\
\text { coeff. } \\
\text { b }\end{array}$ & $\begin{array}{l}\text { Stand. } \\
\text { error } \\
\mathrm{s}_{\mathrm{b}}\end{array}$ & $\underset{t}{\text { Student's }}$ & $\begin{array}{c}\text { Elasti- } \\
\text { city } \\
\text { b* }^{*}\end{array}$ & $\begin{array}{l}\text { Loss of } \\
\text { sum of } \\
\text { squares }\end{array}$ \\
\hline Number of cows $Z_{4}$. & 36.981 & 11.153 & 3.32 & 2.210 & 7.76 \\
\hline Hay yield $\mathrm{Z}_{5} \ldots \ldots \ldots \ldots \ldots$ & -11.292 & 1.797 & 6.29 & -0.879 & 27.88 \\
\hline Lagged hay yield $\mathrm{Z}_{6} \ldots \ldots \ldots \ldots$ & -4.533 & 2.613 & 1.73 & -0.350 & 2.12 \\
\hline Time $\mathrm{T} \ldots \ldots \ldots \ldots \ldots \ldots$ & 0.277 & 0.022 & 12.43 & - & 109.14 \\
\hline Lagged price of beef $(t-4) Z_{7} \ldots$ & 1.957 & 1.057 & 1.85 & 0.220 & 2.42 \\
\hline Lagged price of beef $(t-8) \mathrm{Z}_{8} \ldots$ & 1.040 & 0.974 & 1.07 & 0.120 & 0.81 \\
\hline Seasonal DII $\ldots \ldots \ldots \ldots \ldots \ldots$ & -0.657 & 0.424 & 1.55 & - & 1.69 \\
\hline$\therefore D_{\mathrm{mI}}$ & -0.160 & 0.412 & 0.39 & 一 & 0.11 . \\
\hline $\mathrm{D}_{\mathrm{IF}}$ & 1.140 & 0.431 & 2.65 & 一 & 4.94 \\
\hline
\end{tabular}

Table 14.5. The supply of beef. A linear quarterly model, the total quantity of beef produced as the dependent variable

$\mathrm{R}^{2}=0.949 \mathrm{~s}_{\mathrm{u}}=0.840 \mathrm{~d}=1.206 \mathrm{a}=11.93 \mathrm{SS}_{\mathrm{y}}=414.11$ 
variables are also the most important from the point of view of explanation. Because of the trend in the quantity of beef supplied, time is the most dominating variable. Without it the coefficient of multiple determination would be rather low. As was shown in Section 6.2 , it has a real meaning in the function and it cannot be left out. The estimate of the regression coefficient of the lagged hay yield variable is inconsistent; but it is not statistically significant either.

Both of the lagged producer price of beef variables are positively related to the quantity of beef supplied. The elasticities are not very high, 0.22 and 0.12 respectively, nor are they statistically different from zero. However, they may be worth considering for policy purposes. The low elasticities may have been a result of the fact that price changes were quite small, except

Table 14.6. The supply of beef. A linear quarterly model, the total quantity produced $\left(\mathrm{X}_{\mathrm{b}}\right)$ or the quantity marketed $\left(\mathrm{X}_{\mathrm{bm}}\right)$ as the dependent variable. The standard errors of the estimates are given in parentheses

\begin{tabular}{|c|c|c|c|c|c|c|c|c|c|c|c|}
\hline \multirow{3}{*}{$\begin{array}{l}\text { No. } \\
\text { of } \\
\text { func- } \\
\text { tion }\end{array}$} & \multirow{3}{*}{$\begin{array}{l}\text { De- } \\
\text { pend- } \\
\text { ent } \\
\text { vari- } \\
\text { able }\end{array}$} & \multirow{3}{*}{$R^{2}$} & \multirow{3}{*}{$a$} & \multirow{3}{*}{$\begin{array}{l}\text { Reg. } \\
\text { coeff. } \\
\text { of } \mathrm{T}\end{array}$} & \multicolumn{6}{|c|}{ Elasticity with respect to } & \multirow{3}{*}{$\begin{array}{l}\text { Coeff. of } \\
\text { lagged } \\
\text { quantity } \\
\mathbf{X}_{\mathbf{b m t - b}}\end{array}$} \\
\hline & & & & & \multirow{2}{*}{$\begin{array}{c}\text { Hay } \\
\text { yield } \\
Z_{6}\end{array}$} & \multirow{2}{*}{$\begin{array}{l}\text { No. of } \\
\text { cows } \\
Z_{4}\end{array}$} & \multicolumn{3}{|c|}{ Producer price of beef } & \multirow{2}{*}{$\begin{array}{c}\text { Lagged } \\
\text { hay } \\
\text { yield } \\
Z_{6}\end{array}$} & \\
\hline & & & & & & & $\frac{t-4}{z_{7}}$ & $\frac{t--8}{z_{8}}$ & $\begin{array}{c}\text { Weighted } \\
\text { average } \\
Z_{9}\end{array}$ & & \\
\hline 14.6) & $\mathrm{x}_{\mathrm{bm}}$ & 0.958 & 1.48 & $\begin{array}{c}0.268 \\
(0.020)\end{array}$ & $\begin{array}{r}-0.833 \\
(0.134)\end{array}$ & $\begin{array}{c}1.732 \\
(0.637)\end{array}$ & $\begin{array}{c}0.136 \\
(0.113)\end{array}$ & $\begin{array}{c}0.176 \\
(0.107)\end{array}$ & 二 & $\begin{array}{r}-0.162 \\
(0.193)\end{array}$ & 二 \\
\hline$(14.7)$ & $\mathrm{X}_{\mathrm{b}}$ & 0.949 & 1.21 & $\begin{array}{c}0.278 \\
(0.022)\end{array}$ & $\begin{array}{r}-0.883 \\
(0.118)\end{array}$ & $\begin{array}{c}2.232 \\
(0.555)\end{array}$ & - & - & $\begin{array}{c}0.336 \\
(0.162)\end{array}$ & & 二 \\
\hline 14.8) & $\mathrm{X}_{\mathrm{bm}}$ & 0.957 & 1.51 & & $\begin{array}{r}-0.897 \\
(0.114)\end{array}$ & & 二 & - & $\begin{array}{c}0.268 \\
(0.157)\end{array}$ & & - \\
\hline (14.9) & $\mathrm{X}_{\mathrm{b}}$ & 0.943 & 1.15 & & $\begin{array}{r}-0.982 \\
(0.109)\end{array}$ & & $\overline{-}$ & - & $\begin{array}{c}0.124 \\
(0.119)\end{array}$ & 二 & 二 \\
\hline$(14.10)$ & $\mathrm{X}_{\mathrm{bm}}$ & 0.955 & 1.47 & & $\begin{array}{c}-0.957 \\
(0.102)\end{array}$ & & - & 二 & $\begin{array}{c}0.139 \\
(0.112)\end{array}$ & I & 二 \\
\hline (14.11) & $X_{b m}$ & 0.954 & 1.51 & $\begin{array}{c}0.239 \\
(0.047)\end{array}$ & $\begin{array}{r}-0.950 \\
(0.116)\end{array}$ & $\begin{array}{c}2.266 \\
(0.567)\end{array}$ & $\begin{array}{c}0.119 \\
(0.118)\end{array}$ & - & - & $\begin{array}{r}-0.069 \\
(0.242)\end{array}$ & $\begin{array}{c}0.069 \\
(0.143)\end{array}$ \\
\hline$(14.12)$ & $\mathrm{X}_{\mathrm{bm}}$ & 0.954 & 1.51 & $\begin{array}{c}0.230 \\
(0.033)\end{array}$ & $\begin{array}{r}-0.951 \\
(0.114)\end{array}$ & $\begin{array}{c}2.199 \\
(0.508)\end{array}$ & $\begin{array}{c}0.100 \\
(0.096)\end{array}$ & 二 & - & - & $\begin{array}{c}0.093 \\
(0.117)\end{array}$ \\
\hline (14.13) & $\mathrm{X}_{\mathrm{bm}}$ & 0.953 & 1.46 & $\begin{array}{c}0.252 \\
(0.016)\end{array}$ & $\begin{array}{c}-0.982 \\
(0.106)\end{array}$ & $\begin{array}{c}2.098 \\
(0.489)\end{array}$ & $\begin{array}{c}0.056 \\
(0.078)\end{array}$ & 二 & - & - & 二 \\
\hline$(14.14)$ & $\mathrm{X}_{\mathrm{bm}}$ & 0.953 & 1.43 & $\begin{array}{c}0.249 \\
(0.015)\end{array}$ & $\begin{array}{r}-0.967 \\
(0.103)\end{array}$ & $\begin{array}{c}2.186 \\
(0.470)\end{array}$ & 二 & 二 & - & - & 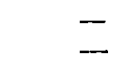 \\
\hline$(14.15)$ & $\mathrm{X}_{\mathrm{bm}}$ & 0.921 & 0.81 & $\begin{array}{c}0.292 \\
(0.015)\end{array}$ & $\begin{array}{c}-0.920 \\
(0.130)\end{array}$ & - & - & $=$ & - & 二 & $=$ \\
\hline (14.16) & $\mathrm{X}_{\mathrm{bm}}$ & 0.806 & 0.43 & $\begin{array}{c}0.238 \\
(0.020)\end{array}$ & - & - & $=$ & - & $\stackrel{-}{-}$ & - & - \\
\hline
\end{tabular}




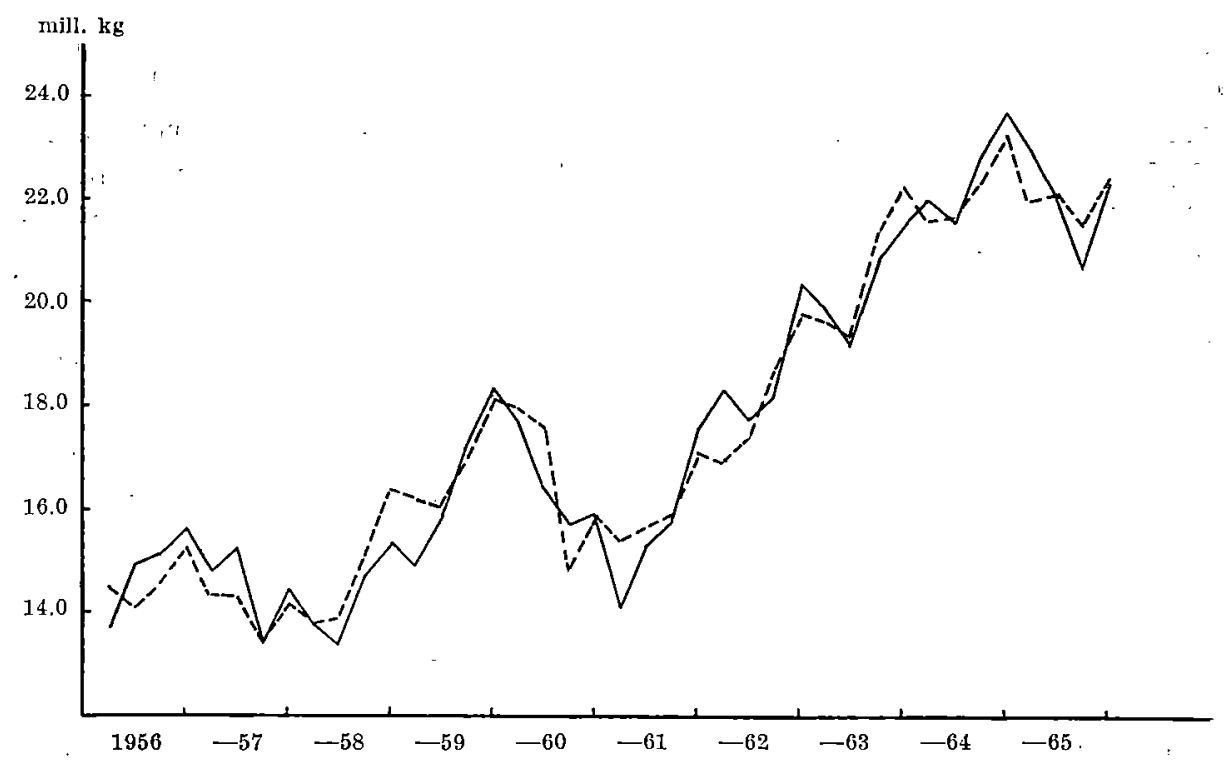

Figure 14.2. The observed values (- $\longrightarrow$ ) of the quantity of beef supplied and the corresponding values (- - - - ) as estimated from function (14.6).

in the last sample year. Thus, we cannot expect to observe any considerable responses of the quantity supplied to the price during the sample period. In recent years the target price of beef has been raised markedly, in order to increase beef production. The data are not yet sufficient to see its effect.

A summary of the results obtained by modifying the supply function for beef is presented in Table 14.6. It should be mentioned, first of all, that the coefficient of multiple determination was invariably somewhat higher for the supply function where the marketed quantity was the dependent variable than for the one with the total quantity supplied as the dependent variable. The serial correlation was also smaller (i.e., $d$ was higher) in the second case, as compared with the first. This was perhaps due to the way in which the quarterly data on total production were formed.

The significance of the lagged producer price of beef was tested by including an arbitrarily (and also according to the coefficients of price variables in (14.5)) weighted average $Z_{9}=0.667 Z_{7}+0.333 Z_{8}$ in the function. For the total supply function (14.7) the price elasticity, 0.34, was statistically significant, but this was not so for the market supply function. The former function is likely to be more reliable here, since slaughterings on farms may increase with increasing production, i.e. if the current producer price is low, thus disturbing the price response in the market supply function. The same phenomenon is seen in functions (14.5) and (14.6), where the lagged prices are used separately. 
The Nerlove model (14.11) contributed practically nothing to the model, since the coefficient of the lagged dependent variable was insignificant and, hence, the increase in the coefficient of multiple determination was small.

The test of serial correlation of the residuals was inconclusive for all functions, even though the function explaining the marketed quantities seemed to be almost acceptable in this respect.

As a summary of Table 14.6 it may be stated that the three main factors determing the quantity of beef supplied are the number of cows, hay yield and the time variable, which represents the long run effect of hay yield, as was concluded when the function (6.2) was derived. To these we might add the lagged producer price of beef $(t-4)$ or the weighted average of the two lagged prices. The coefficient of multiple determination is not, however, greatly affected by them or by the other variables which were included in the supply function. The fit of the function (14.14) is illustrated in Figure 14.2. It represents quite, well all the functions in Table 14.6.

Table 14.6 shows that the estimates of the parameters are rather stable from a function to another. This is, perhaps, an indication of the absence of multicollinearity.

After experiments with several variables in the quarterly model, it was regarded as sufficient to include only the three main variables in the $\mathrm{se} \mathrm{m}$ ia $n \mathrm{n}$ a $l$ models, the estimates of which are given in Tables 14.7 and 14.8.

Table 14.7. The supply of beef. A linear semiannual model, the quantity of beef marketed as the dependent variable

\begin{tabular}{|c|c|c|c|c|c|}
\hline $\begin{array}{c}\text { Explanatory } \\
\text { variable }\end{array}$ & $\begin{array}{l}\text { Reg. } \\
\text { coeff. } \\
\text { b }\end{array}$ & $\begin{array}{l}\text { Stand. } \\
\text { error } \\
\text { s }_{\mathbf{b}}\end{array}$ & $\underset{t}{\text { Student's }}$ & $\begin{array}{c}\text { Elasti- } \\
\text { city } \\
b^{*}\end{array}$ & $\begin{array}{l}\text { Loss of } \\
\text { sum of } \\
\text { squares }\end{array}$ \\
\hline Hay yield $\mathrm{Z}_{5}$ & -22.783 & 2.910 & 7.83 & -0.967 & 97.93 \\
\hline Number of cows $\mathrm{Z}_{4} \ldots \ldots \ldots$ & 67.118 & 17.313 & 3.88 & 2.186 & 24.01 \\
\hline Time T $\ldots \ldots \ldots \ldots \ldots \ldots$ & 0.995 & 0.072 & 13.72 & - & 301.13 \\
\hline Seasonal $D_{I I} \ldots \ldots \ldots \ldots$ & 0.010 & 0.604 & 0.02 & - & 0.00 \\
\hline
\end{tabular}

$\mathrm{R}^{2}=0.968 \mathrm{su}=1.26 \mathrm{~d}=1.79 \mathrm{a}=-19.19 \mathrm{SS}_{\mathrm{y}}=748.31$

Table 14.8. The supply of beef. A linear semiannual model, the total quantity of beef produced as the dependent variable

\begin{tabular}{|c|c|c|c|c|c|}
\hline $\begin{array}{l}\text { Explanatory } \\
\text { variable }\end{array}$ & $\underset{\text { Reg. }}{\text { coef. }}$ & $\begin{array}{c}\text { Stand. } \\
\text { error } \\
\mathbf{s}_{\mathbf{b}}\end{array}$ & $\underset{t}{\text { Student's }}$ & $\underset{\substack{\text { Elasti- } \\
\text { city }}}{\text { b }}$ & $\begin{array}{l}\text { Loss of } \\
\text { sum of } \\
\text { squares }\end{array}$ \\
\hline Hay yield $Z_{5}$. & -25.480 & 3.569 & 7.14 & -0.992 & 122.47 \\
\hline Number of cows $Z_{4} \ldots \ldots \ldots$ & 74.594 & 21.232 & 3.51 & 2.229 & 29.66 \\
\hline Time $\mathrm{T} \ldots \ldots \ldots \ldots \ldots \ldots$ & 0.990 & 0.089 & 11.14 & - & 298.34 \\
\hline Seasonal DII $\ldots \ldots \ldots \ldots$ & 1.274 & 0.741 & 1.72 & - & 7.11 \\
\hline
\end{tabular}

$\mathrm{R}^{2}=0.955 \mathrm{~s}_{\mathrm{u}}=1.55 \mathrm{~d}=1.39 \mathrm{a}==-20.15 \mathrm{SS}_{\mathrm{y}}=804.57$ 
The function of the marketed quantity of beef meets all the statistical requirements, provided the seasonal dummy variable whose coefficient is about zero is disregarded. Seasonal variations were shown by the quantity produced, but these were obviously accounted for by the number of cows, the seasonal variations in which were about the same. The coefficients were all highly significant, the coefficient of multiple determination was high, and there was no serial correlation in the residuals. The standard error, $\mathrm{s}_{\mathrm{u}}=1.26$, was rather low compared to the average value, $35.3 \mathrm{mill}$. $\mathrm{kg}$, of the dependent variable. This model, as well as the function of the total quantity of beef supplied, seems to be rather good for prediction.

\section{Estimates for the recursive model}

First the entire price formation part of the recursive model will be presented and then each equation will be discussed separately. All equations were estimated by the method of least squares. The standard errors of the regression coefficients will be given in parentheses. The fit of the functions, in addition to the coefficient of multiple determination and the standard error of the estimate (of the residuals), will be illustrated by figures which also give an idea of the serial correlation of the residuals.

$$
\begin{aligned}
\mathrm{Im}-\mathrm{Ex}_{\mathrm{p}}= & 1.408-0.432 \mathrm{X}_{\mathrm{p}}-0.021 \mathrm{Y}-0.040 \mathrm{D}_{\mathrm{II}}+0.245 \mathrm{D}_{\mathrm{III}} \\
(0.066) \quad(0.245) \quad(0.046) \quad(0.059) & \\
+ & 0.450 \mathrm{D}_{\mathrm{IV}}+\mathrm{u}_{\mathrm{imp}} \\
(0.084) & \mathrm{R}^{2}=0.568 \mathrm{~s}_{\mathrm{u}}=0.103 \mathrm{~d}=2.32
\end{aligned}
$$

$$
\begin{aligned}
& \operatorname{Im}-\mathrm{Ex}_{\mathrm{b}}=-0.997-0.421 \mathrm{X}_{\mathrm{b}}+3.229 \mathrm{Y}-0.077 \mathrm{D}_{\mathrm{II}}+0.033 \mathrm{D}_{\text {IXI }} \\
& \begin{array}{llll}
(0.087) & (0.783) & (0.073) & (0.072)
\end{array} \\
& +0.106 \mathrm{D}_{\mathrm{IV}}+\mathrm{u}_{\mathrm{imp}} \\
& (0.078) \\
& \mathrm{R}^{2}=0.415 \mathrm{~s}_{\mathrm{u}}=0.161 \mathrm{~d}=1.09
\end{aligned}
$$

$$
\begin{array}{cc}
\mathrm{P}_{\mathrm{pr}}= & 2.196-0.304 \mathrm{C}_{\mathrm{p}}-0.212 \mathrm{C}_{\mathrm{b}}+2.651 \mathrm{Y}-0.148 \mathrm{D}_{\mathrm{II}}+0.117 \mathrm{D}_{\mathrm{III}} \\
(0.123)(0.093) & (0.789) \quad(0.061) \\
+0.378 \mathrm{D}_{\mathrm{IV}}+\mathrm{u}_{\mathrm{pr}} & \mathrm{R}^{2}=0.405 \mathrm{~s}_{\mathrm{u}}=0.131 \mathrm{~d}=0.94 \\
(0.147) &
\end{array}
$$

$$
\begin{aligned}
& \mathrm{P}_{\mathrm{br}}=1.066-0.511 \mathrm{C}_{\mathrm{b}}+0.115 \mathrm{C}_{\mathrm{p}}+3.359 \mathrm{Y}-0.013 \mathrm{D}_{\text {II }}+0.091 \mathrm{D}_{\mathrm{JII}} \\
& \begin{array}{lllll}
(0.079) \quad(0.105) \quad(0.673) & (0.052) \quad(0.078)
\end{array} \\
& +0.059 \mathrm{D}_{\mathrm{IV}}+\mathrm{u}_{\mathrm{br}} \\
& \text { (0.125) } \\
& \mathrm{R}^{2}=0.628 \mathrm{~s}_{\mathrm{u}}=0.112 \mathrm{~d}=1.06
\end{aligned}
$$




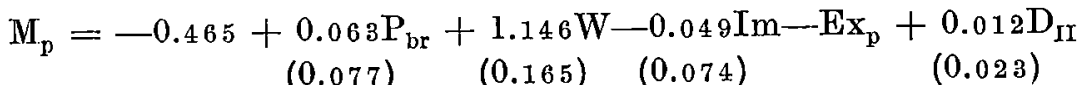

$$
\begin{aligned}
& +0.034 \mathrm{D}_{\mathrm{III}}+0.018 \mathrm{D}_{\mathrm{IV}}+\mathrm{u}_{\mathrm{mp}} \\
& \text { (0.023) (0.024) } \\
& \mathrm{R}^{2}=0.730 \mathrm{~s}_{\mathrm{u}}=0.050 \mathrm{~d}=1.10
\end{aligned}
$$

$$
\begin{aligned}
& \mathrm{M}_{\mathrm{b}}=0.236+0.096 \mathrm{P}_{\mathrm{pr}}+0.036 \mathrm{~W}-0.153 \mathrm{Im}-\mathrm{Ex}_{\mathrm{b}}-0.063 \mathrm{D}_{\mathrm{II}} \\
& (0.092) \cdot(0.237) \quad(0.075) \\
& +0.032 \mathrm{D}_{\mathrm{III}}+0.042 \mathrm{D}_{\mathrm{IV}}+\mathrm{u}_{\mathrm{mb}} \\
& (0.040) \quad(0.039) \\
& \mathrm{R}^{2}=0.294 \mathrm{~s}_{\mathrm{u}}=0.086 \mathrm{~d}=0.59
\end{aligned}
$$

and the identities

$$
\begin{aligned}
& \mathrm{C}_{\mathrm{p}} \equiv \mathrm{X}_{\mathrm{p}}+\mathrm{Im}-\mathrm{Ex}_{\mathrm{p}}, \\
& \mathrm{C}_{\mathrm{b}} \equiv \mathrm{X}_{\mathrm{b}}+\mathrm{Im}-\mathrm{Ex}_{\mathrm{b}}, \\
& \mathrm{P}_{\mathrm{pp}} \equiv \mathrm{P}_{\mathrm{pr}}-\mathrm{M}_{\mathrm{p}} \\
& \mathrm{P}_{\mathrm{bp}} \equiv \mathrm{P}_{\mathrm{br}}-\mathrm{M}_{\mathrm{b}} .
\end{aligned}
$$

The main determinant of net imports of pork seems to be the quantity produced $\left(\mathrm{X}_{\mathrm{p}}\right)$. The low income coefficient is obviously due to the low income elasticity of the demand for pork, which is indicated by a rather stable per capita consumption and which is also confirmed by the statistical analysis as will be seen later on. By contrast, the influence of income (Y) on net imports of beef is clear, and the corresponding regression coefficient is statistically significant. The coefficient of production $(X)$ is negative in both equations, as it should be. The coefficient of multiple determination is, however, low, which may be interpreted to reflect that the decions made with regard to imports or exports of meat are partly exogenous, not explained by the model, as was assumed earlier in Section 6.5. The fit of the net imports functions are illustrated by Figures 15.1 and 15.2.

Since the demand functions are the main functions in the model, they will also be presented in Tables 15.3 and 15.4 in greater detail. Even though the coefficient of multiple determination for pork is low, the regression coefficients are acceptable as to their sign and size, and they are also statistically significant (except that for $\mathrm{D}_{\mathrm{III}}$, but much attention will not be paid to the significance of the coefficients of the seasonal dummy variables, since some of them can be expected to be close to zero, and thus it easily happens that they do not prove significant in the statistical sense).

The coefficient of multiple determination for the demand function for beef is higher than that for pork, but the function is not completely satis-

$8 \quad 8609-68$ 


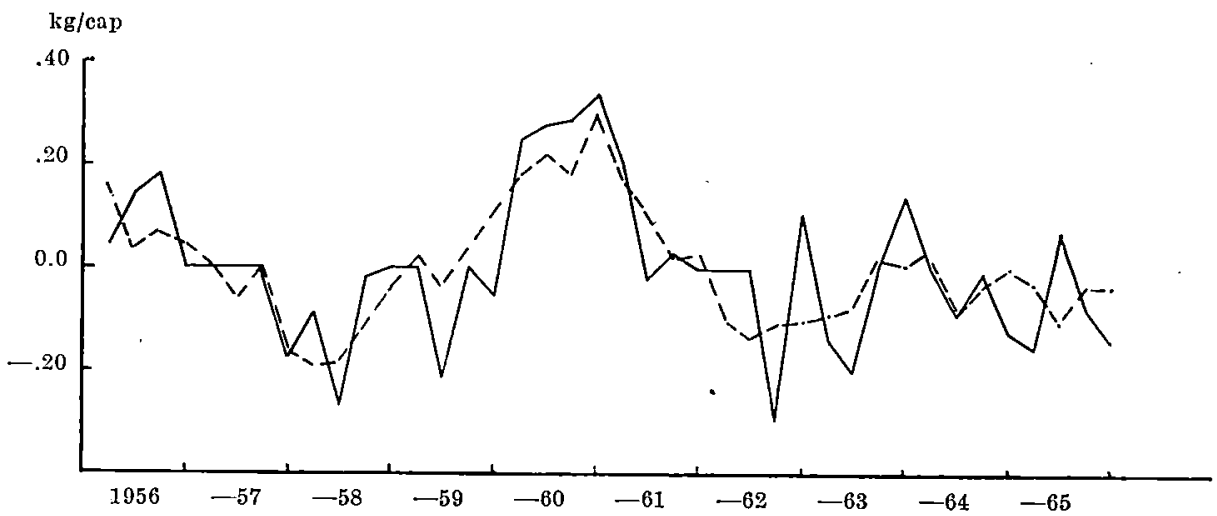

Figure 15.1. The observed values ( $\longrightarrow$ ) of net imports of pork and the corresponding values (-- - ) as estimated from function (15.1).

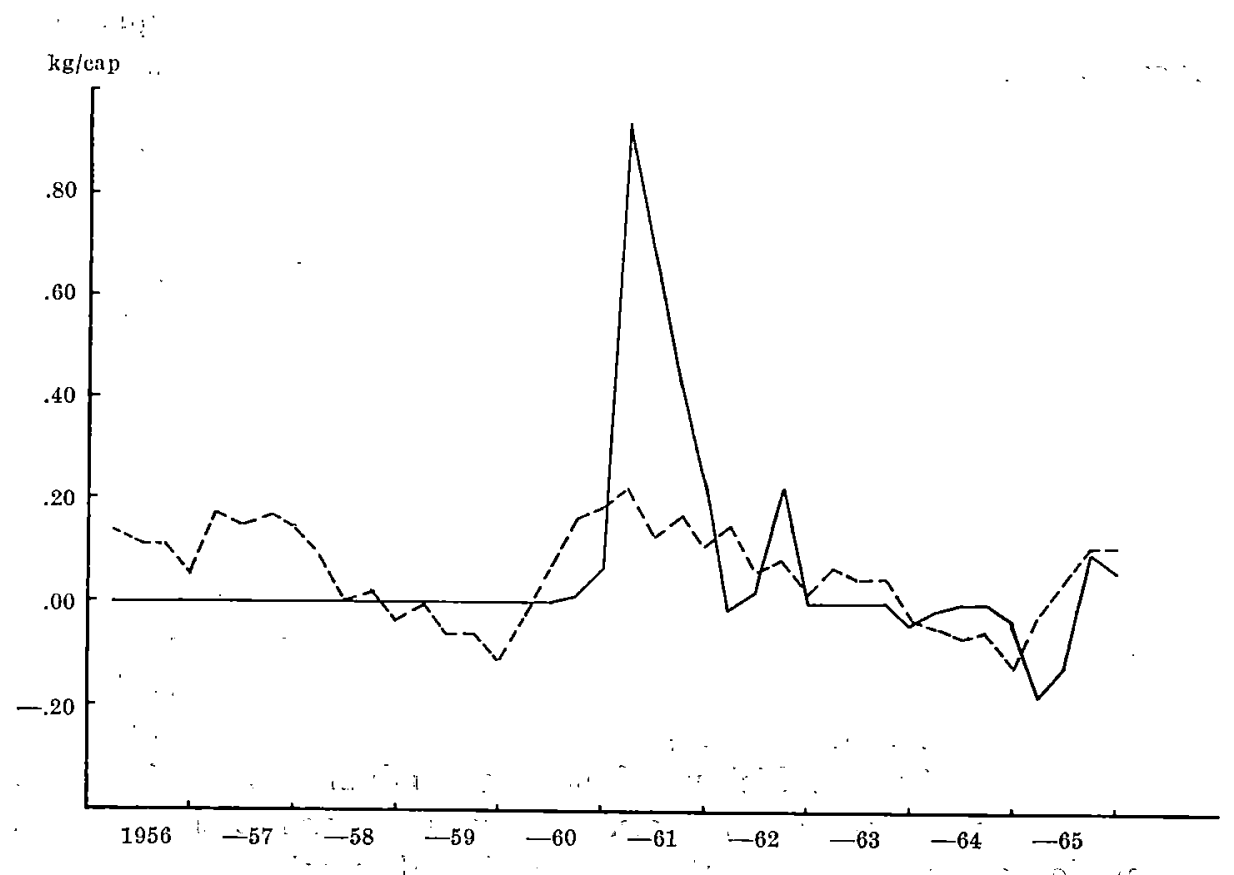

Figure 15.2. The observed values $(\longrightarrow$ ) of net imports of beef and the corresponding values (-.--) as estimated from function (15.2). 
Table 15.3. The demand for pork. A linear quarterly model, the deflated retail price of pork as the dependent variable

\begin{tabular}{|c|c|c|c|c|c|}
\hline $\begin{array}{c}\text { Explanatory } \\
\text { variable }\end{array}$ & $\begin{array}{l}\text { Reg. } \\
\text { coeff. } \\
\text { b }\end{array}$ & $\begin{array}{l}\text { Stand. } \\
\text { error } \\
\mathbf{8}_{\mathbf{b}}\end{array}$ & $\underset{t}{\text { Student's }}$ & $\begin{array}{l}\text { Flexi- } \\
\text { bility } \\
\text { b }^{*}\end{array}$ & $\begin{array}{l}\text { Loss of } \\
\text { sum of } \\
\text { squares }\end{array}$ \\
\hline 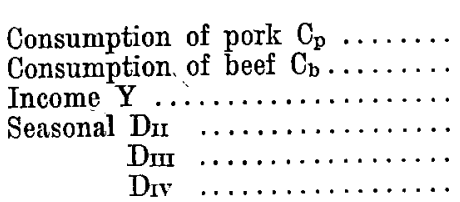 & $\begin{array}{r}-0.304 \\
-0.212 \\
2.651 \\
-0.148 \\
0.117 \\
0.378\end{array}$ & $\begin{array}{l}0.123 \\
0.093 \\
0.789 \\
0.061 \\
0.092 \\
0.147\end{array}$ & $\begin{array}{l}2.46 \\
2.29 \\
3.36 \\
2.43 \\
1.27 \\
2.58\end{array}$ & $\begin{array}{r}-0.418 \\
-0.355 \\
0.899 \\
- \\
-\end{array}$ & $\begin{array}{l}0.105 \\
0.091 \\
0.195 \\
0.102 \\
0.028 \\
0.115\end{array}$ \\
\hline
\end{tabular}

$\mathrm{R}^{2}=0.405 \mathrm{~s}_{\mathrm{u}}=0.131 \mathrm{~d}=0.94 \mathrm{a}=2.196 \mathrm{SS}_{\mathrm{y}}=0.956$

factory, since the cross flexibility is positive with respect to the consumption of pork $\left(\mathrm{C}_{\mathrm{p}}\right)$, which is not in accordance with the a priori assumptions. However, it is not statistically significant and is close to zero. It may be that pork is no substitute for beef. Some studies made in the U.S.A.have given similar results. ${ }^{1}$ One reason for this may be the fact that the supply of beef has developed in such a way that there has been no reason to substitute pork for beef, and therefore, we cannot get any cross flexibility by estimation. Price flexibility $(-0.995)$ and income elasticity (1.322) are rather plausible. According to the estimates of the coefficients of the seasonal dummy variables the seasonal variation in the retail price of beef is rather small.

In the case of pork, income is the most important variable and in the case of beef the consumption of beef is the most important variable, considering the explanation of the variance of the dependent variable. The test for the serial correlation of the residuals is inconclusive for both demand functions (see also Figures 15.3 and 15.4, where the actual and computed values of the retail prices are given).

Table 15.4. The demand for beef. A linear quarterly model, the deflated retail price of beef as the dependent variable

\begin{tabular}{|c|c|c|c|c|c|}
\hline$\underset{\text { variable }}{\text { Explanatory }}$ & $\begin{array}{l}\text { Reg. } \\
\text { coeff. } \\
\mathrm{b}\end{array}$ & $\begin{array}{l}\text { Stand. } \\
\text { error } \\
\text { sb }\end{array}$ & $\underset{t}{\text { Student's }}$ & $\begin{array}{l}\text { Flexi- } \\
\text { bility } \\
\mathrm{b}^{*}\end{array}$ & $\begin{array}{l}\text { Loss of } \\
\text { sum of } \\
\text { squares }\end{array}$ \\
\hline Consumption of beef $\mathrm{C}_{\mathrm{b}}$. & -0.511 & 0.079 & 6.48 & -0.995 & 0.527 \\
\hline Consumption of pork $\mathrm{C}_{\mathrm{p}} \ldots \ldots \ldots$ & 0.155 & 0.105 & 1.09 & 0.184 & 0.015 \\
\hline Income $Y \ldots \ldots \ldots \ldots \ldots \ldots$ & 3.359 & 0.673 & 4.99 & 1.322 & 0.313 \\
\hline Seasonal Dir $\ldots \ldots \ldots \ldots \ldots$ & -0.013 & 0.052 & 0.25 & 一 & 0.001 \\
\hline$D_{\text {III }} \ldots \ldots \ldots \ldots \ldots$ & 0.091 & 0.078 & 1.16 & 一 & 0.017 \\
\hline$D_{I V} \quad \ldots \ldots \ldots \ldots \ldots \ldots$ & 0.059 & 0.125 & 0.47 & & 0.028 \\
\hline \multicolumn{6}{|c|}{$\begin{array}{l}\mathrm{R}^{2}=0.628 \mathrm{~s}_{\mathrm{u}}=0.112 \mathrm{~d}=1.059 \mathrm{a}=1.066 \mathrm{SS}_{\mathrm{y}}=1.113 \\
\quad \text { srit., p. } 12 .\end{array}$} \\
\hline
\end{tabular}




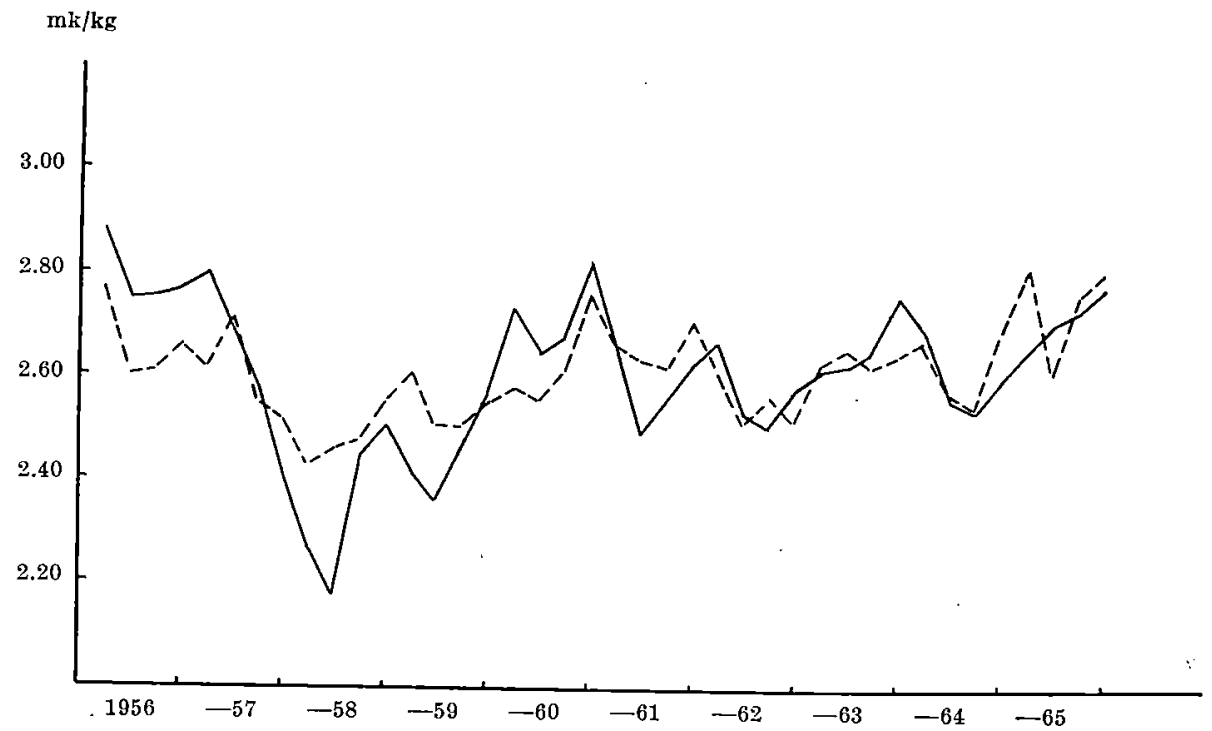

Figure 15.3. The observed values (- $\longrightarrow$ ) of the retail price of pork and the corresponding values (---) as estimated from function (15.3).

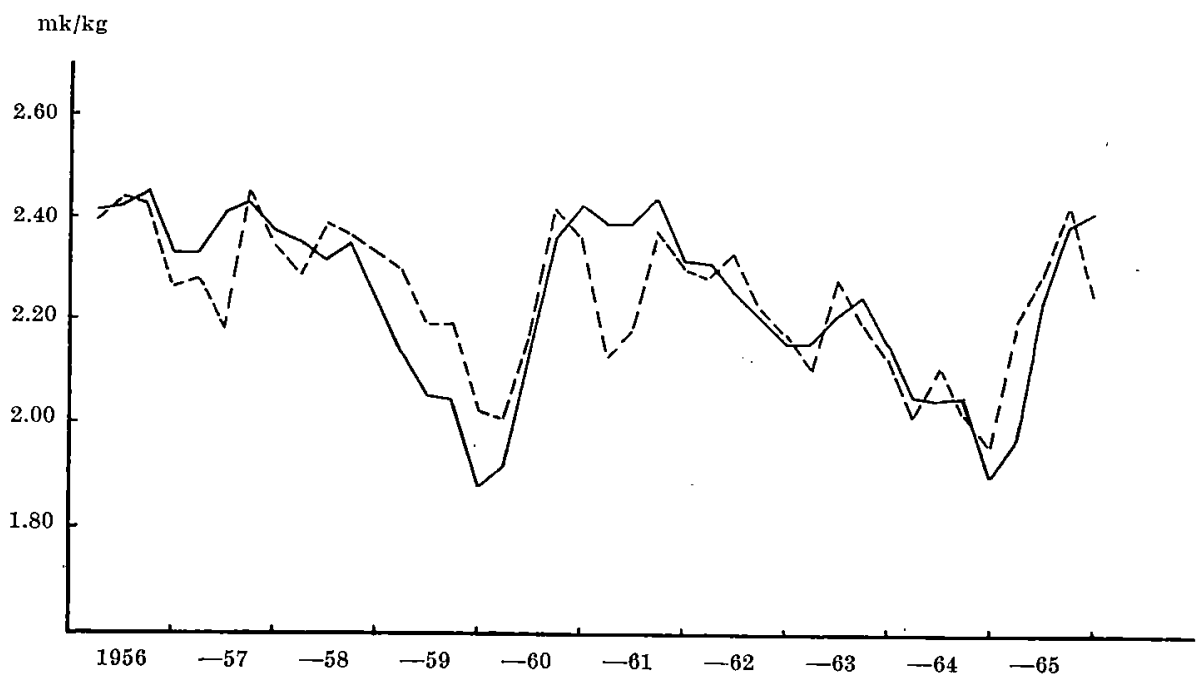

Figure 15.4. The observed values $(\longrightarrow$ ) of the retail price of beef and the corresponding values (...-) as estimated from function (15.4). 


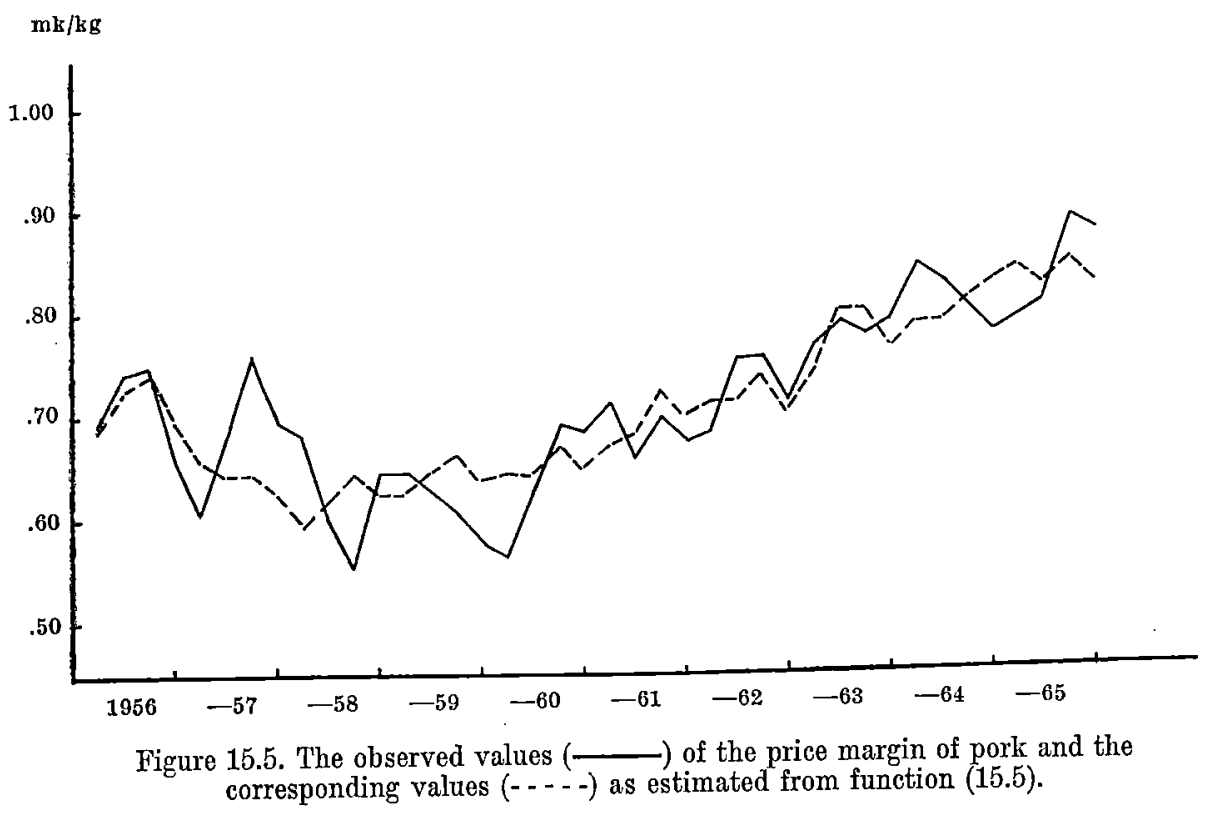

The price margin function for pork is satisfactory. $\mathrm{R}^{2}$ is rather high (see also Figure 15.5) and the estimates of the regression coefficients are logical regarding their signs. Wages are the most important variable in the equation. The positive coefficient of $\mathrm{P}_{\mathrm{pr}}$ shows that a higher retail price also means a higher margin even though the dependence is rather weak, and the negative coefficient of $\mathrm{Im}-\mathrm{Ex}_{\mathrm{p}}$ indicates that a low price of imports allows a higher producer price which reduces the price margin.

The price margin function for beef did not come out satisfactorily. The estimates of the coefficients are certainly logical but they are not statistically significant and as a whole the degree of explanation of the function, i.e., $\mathrm{R}^{2}$, is low which is also seen from Figure 15.6. The reason for this is that the margin increased quite rapidly in 1958, after which it decreased again. There does not seem to be any rational explanation for that.

In order to test the assumption of the non-correlation of the disturbances of different functions, the linear correlation matrix of the computed residuals was calculated (table 15.5). The only correlation coefficient which is statistically different from zero is $r_{56}(=0.581)$, i.e., that between the residuals of the demand functions. ${ }^{1}$ Otherwise the correlations are close to zero. We cannot, however, conclude that the theoretical assumption of non-correlation

1 The confidence limits given in the tables refer to tests of single estimates. When a group of estimates, as in this case, is tested, the number of estimates has to be taken into account, i.e., the test is less restrictive for the whole table. 


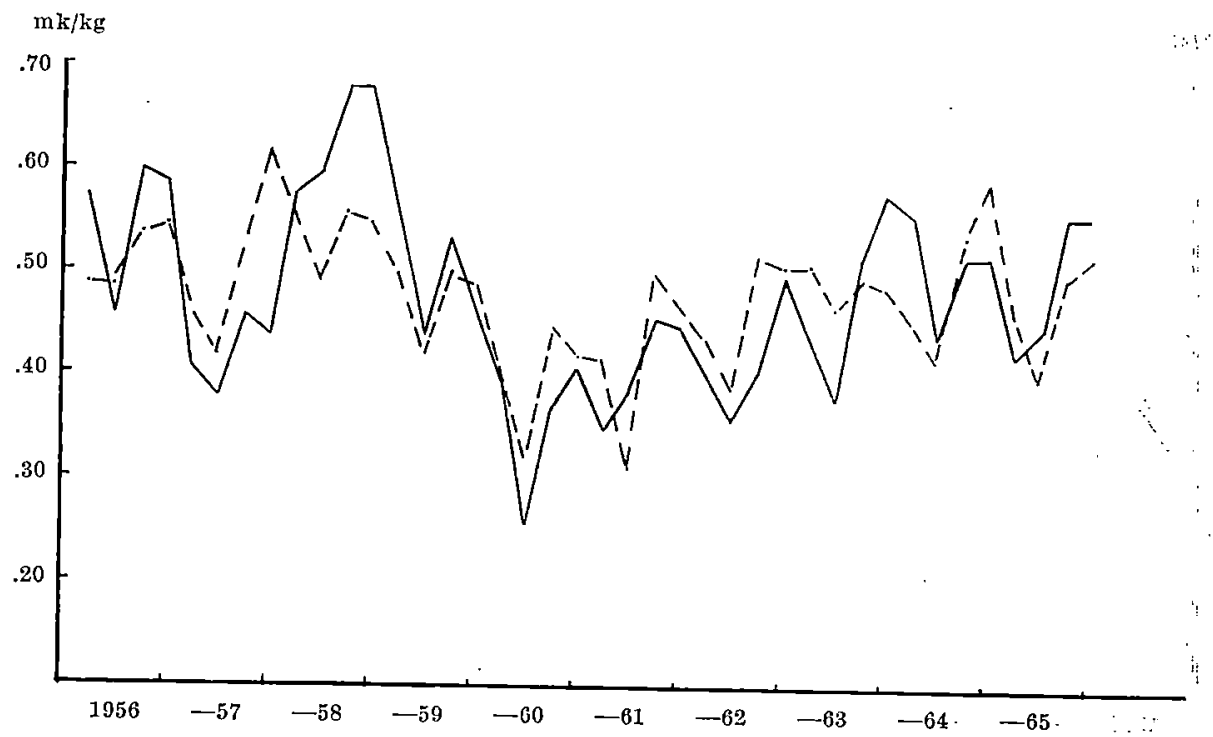

Figure 15.6. The observed values $(\longrightarrow$ ) of the price margin of beef and the : corresponding values (-...) as estimated from function (15.6).

of the disturbances is valid, since the test concerns only the linear correlations.

M o d e I IIa is obtained from the model II by replacing the functions (15.3)-(15.4) by the following functions (the elasticities are given in brackets): ${ }^{1}$

Table 15.5. The matrix linear correlation coefficients of the computed residuals of the quarterly recursive model II a

\begin{tabular}{|c|c|c|c|c|c|c|c|c|}
\hline \multirow{2}{*}{$\begin{array}{l}\text { Re- } \\
\text { siduals }\end{array}$} & \multicolumn{2}{|c|}{ Supply of } & \multicolumn{2}{|c|}{$\operatorname{Im}-\mathrm{Ex}$ of } & \multicolumn{2}{|c|}{ Demand for } & \multicolumn{2}{|c|}{ Price margin of } \\
\hline & pork & $\begin{array}{c}\text { beef } \\
\mathrm{u}_{3}\end{array}$ & $\underset{\mathrm{u}_{3}}{\text { pork }}$ & $\begin{array}{c}\text { beef } \\
\mathrm{u}_{4}\end{array}$ & $\underset{\mathbf{u}_{5}}{\text { pork }}$ & $\begin{array}{c}\text { beef } \\
u_{6}\end{array}$ & $\underset{\mathrm{u}_{i}}{\text { pork }}$ & $\begin{array}{c}\text { beef } \\
u_{B}\end{array}$ \\
\hline$u_{1} \ldots \ldots$ & 1.0 & 0.120 & -0.021 & 0.031 & 0.040 & -0.000 & 0.145 & 0.394 \\
\hline$u_{2} \ldots \ldots$ & 一 & 1.0 & 0.217 & -0.257 & 0.234 & 0.157 & -0.096 & -0.362 \\
\hline $\mathrm{u}_{3} \ldots \ldots$ & 一 & - & 1.0 & -0.157 & 0.000 & 0.001 & 0.219 & -0.108 \\
\hline$u_{4} \ldots \ldots$ & - & 一 & - & 1.0 & -0.000 & -0.000 & -0.096 & $0: 018$ \\
\hline$u_{5} \ldots \ldots$ & - & 一 & - & - & 1.0 & 0.581 & 0.033 & -0.205 \\
\hline $\mathrm{u}_{6} \ldots \ldots$ & - & 一 & 一 & 一 & - & 1.0 & 0.231 & -0.004 \\
\hline $\mathrm{u}_{7} \ldots \ldots$ & 一 & 一 & - & - & - & - & 1.0 & -0.243 \\
\hline$u_{8} \ldots \ldots$ & 一 & - & - & 一 & 一 & 一 & - & 1.0 \\
\hline
\end{tabular}

${ }^{1}$ For $n=40 \mathrm{r}$ has to be at least $=0.31$ at the 95 per cent and $=0.40$ at the 99 per cent confidence level in order to be significantly different from zero.

a For comparisons, KaARLEHTO obtained the following elasticity estimates for pork: -1.130 with respect to pork production and 0.997 with respect to income. Sianlihan markkinoinnista, op. cit., p. 35. The estimated functions are not, however, strictly comparable. 


$$
\begin{gathered}
\mathrm{P}_{\mathrm{pr}}=1.953-0.228 \mathrm{X}_{\mathrm{p}}-0.176 \mathrm{X}_{\mathrm{b}}+0.320 \mathrm{Im}-\mathbf{E x}_{\mathrm{p}}-0.304 \mathrm{Im}-\mathbf{E x}_{\mathrm{b}} \\
(0.103)(0.073) \\
{[-0.314][-0.290]} \\
+2.479 \mathrm{Y}-0.121 \mathrm{D}_{\mathrm{II}}+0.070 \mathrm{D}_{\mathrm{III}}+0.284 \mathrm{D}_{\mathrm{IV}}+\mathrm{u}_{\mathrm{pr}} \\
(0.617)(0.048) \quad(0.075) \quad(0.120) \\
{[0.840]} \\
\mathrm{R}^{2}=0.659 \mathrm{~s}_{\mathrm{u}}=0.103 \mathrm{~d}=0.89
\end{gathered}
$$

$$
\begin{aligned}
& P_{b r}=0.629-0.505 X_{b}+0.242 X_{p}-0.169 I m-E_{b}+0.361 \mathrm{Im}-\mathrm{Ex}_{\mathrm{p}} \\
& \begin{array}{lll}
(0.063) & (0.089) \quad(0.098)
\end{array} \\
& {[-0.968] \quad[0.386]} \\
& +3.330 \mathrm{Y}+0.006 \mathrm{D}_{\mathrm{II}}+0.017 \mathrm{D}_{\mathrm{III}}-0.061 \mathrm{D}_{\mathrm{IV}}+\mathrm{u}_{\mathrm{br}} \\
& \begin{array}{llll}
(0.533) & (0.041) & (0.064) & (0.104)
\end{array} \\
& {[1.310]} \\
& \mathrm{R}^{2}=0.782 \mathrm{~s}_{\mathrm{u}}=0.089 \mathrm{~d}=1.49
\end{aligned}
$$

The fit of these demand functions is much better than that of the corresponding demand functions (15.3) and (15.4) in model II. The wrong signs of the pork variables, however, disturb the analysis to some extent, and in this case the estimates are even statistically significant. The positive coefficient of $\mathrm{Im}-\mathrm{Ex}_{\mathrm{p}}$ in (15.7) may, however, merely reflect the pork market situation: when the price is high, imports are necessary, and when the price is low, the positive correlation indicates a need for exports.

The signs of the production of pork and its net imports in the demand function for beef are also incompatible with the a priori expectation. Only the behavior of beef is comprehensible and the test of the different influence of production and imports-exports on price is possible (see Section 6.3). In the case of the demand for pork (15.7), net imports of beef (the regression coefficient of $\operatorname{Im}-\mathbf{E x}_{\mathrm{b}}=-\mathbf{0 . 3 0 4}$ ) seem to have affected the pork price more than did the production of beef (the regression coefficient of $\mathrm{X}_{\mathrm{b}}=$ -0.176 ), whereas in the case of the demand for beef (15.8) the coefficient of beef production $\mathrm{X}_{\mathrm{b}}(=0.505)$ is clearly higher than that of the $I m-\mathbf{E x}_{\mathrm{b}}$ variable $(=-0.169)$, which means that a change in beef production has more influence on beef price than a similar change in net imports. The unsatisfactory coefficients of the pork variables make, however, the test rather uncertain.

The estimates obtained when the se mi a n n u a l d a ta was applied can be presented briefly as follows: 
$(15.9)$

$$
\begin{gathered}
\operatorname{Im}-\mathrm{Ex}_{\mathrm{p}}=3.107-0.484 \mathrm{X}_{\mathrm{p}}-0.066 \mathrm{Y}+0.844 \mathrm{D}_{2}+\mathrm{u}_{\mathrm{imp}} \\
(0.051) \quad(0.356) \quad(0.097) \\
\mathrm{R}^{2}=0.853 \mathrm{~s}_{\mathrm{u}}=0.105 \mathrm{~d}=2.09
\end{gathered}
$$

(15.10) $\mathrm{Im}-\mathrm{Ex}_{\mathrm{b}}=-2.225-0.436 \mathrm{X}_{\mathrm{b}}+6.772 \mathrm{Y}+0.225 \mathrm{D}_{2}+\mathrm{u}_{\mathrm{imb}}$

$$
\begin{array}{lll}
(0.126) & (2.266) & (0.157)
\end{array}
$$

$$
\mathrm{R}^{2}=0.427 \mathrm{~s}_{\mathrm{u}}=0.315 \mathrm{~d}=1.94
$$

$$
\begin{aligned}
\text { (15.11) } \mathrm{P}_{\mathrm{pr}}=2.705-0.272 \mathrm{C}_{\mathrm{p}}-0.128 \mathrm{C}_{\mathrm{b}}+3.047 \mathrm{Y}+0.545 \mathrm{D}_{2}+\mathrm{u}_{\mathrm{pr}} \\
(0.104)(0.063) \quad(1.071) \quad(0.192) \\
\mathrm{R}^{2}=0.504 \mathrm{~s}_{\mathrm{u}}=0.118 \mathrm{~d}=1.23
\end{aligned}
$$

(15.12) $\mathrm{P}_{\mathrm{br}}=0.994-0.285 \mathrm{C}_{\mathrm{b}}+0.034 \mathrm{C}_{\mathrm{p}}+3.884 \mathrm{Y}+0.134 \mathrm{D}_{2}+\mathrm{u}_{\mathrm{br}}$

$$
\begin{array}{ll}
(0.053) \quad(0.087) \quad(0.896) \quad(0.160) \\
\\
R^{2}=0.697 \mathrm{~s}_{\mathrm{u}}=0.099 \mathrm{~d}=1.64
\end{array}
$$

(15.13) $\mathrm{M}_{\mathrm{p}}=-0.534+0.109 \mathrm{P}_{\mathrm{pr}}+1.092 \mathrm{~W}-0.079 \mathrm{Im}-\mathbf{E x}_{\mathrm{p}}$

$$
\begin{aligned}
& \begin{array}{lll}
(0.095) \quad(0.196) \quad(0.051) &
\end{array} \\
& +0.020 \mathrm{D}_{\mathrm{a}}+\mathrm{u}_{\mathrm{mp}} \\
& \text { (0.017) } \\
& \mathrm{R}^{2}=0.837 \mathrm{~s}_{\mathrm{u}}=0.039 \mathrm{~d}=2.02
\end{aligned}
$$

(15.14) $\mathrm{M}_{\mathrm{b}}=0.227+0.085 \mathrm{P}_{\mathrm{br}}+0.037 \mathrm{~W}-0.070 \mathrm{Im}-\mathrm{Ex}_{\mathrm{b}}$

$$
\begin{array}{lll}
(0.137) & (0.338) & (0.055) \\
+0.069 \mathrm{D}_{2}+\mathrm{u}_{\mathrm{mb}} & & \\
(0.039) & \mathrm{R}^{2}=0.263 \quad \mathrm{~s}_{\mathrm{u}}=0.086 \mathrm{~d}=1.22
\end{array}
$$

the identities being the same as previously.

As a general feature of the semiannual model compared to the quarterly model, it can be seen that $R^{2}$ rose for all functions except the last one, i.e., the price margin function for beef which is the worst function in the model in that sense. Particularly, $\mathrm{R}^{2}$ for the net imports function for pork increased markedly. The price flexibilities and elasticities are about the same as those for the quarterly model, and the same problem with respect to the substitution assumption of pork for beef is also faced with here (function (15.12)). - Serial correlation of the residuals is smaller for the semiannual model than for the quarterly model. 
Table 15.6. The matrix of the linear correlation coefficients of the computed residuals of the semiannual model II 1 .

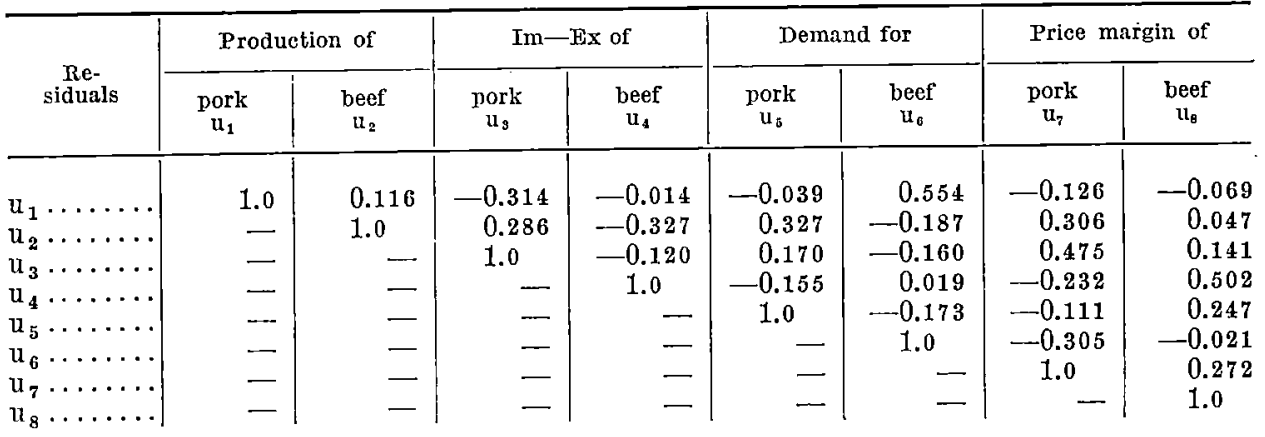

1 For $\mathrm{n}=20 \mathrm{r}$ has to be $\geq 0.44$ at the 95 per cent and $\geq 0.56$ at the 99 per cent confidence level in order to be significantly different from zero.

The demand functions of the semiannual model IIa are as follows:

$$
\begin{aligned}
& \mathrm{P}_{\mathrm{pr}}=1.706-0.096 \mathrm{X}_{\mathrm{p}}-0.097 \mathrm{X}_{\mathrm{b}}+0.208 \mathrm{Im}-\mathbf{E} \mathbf{x}_{\mathrm{p}}-\mathbf{0 . 1 7 1 \mathrm { Im } - \mathbf { E x }} \mathrm{x}_{\mathrm{b}} \\
& \begin{array}{lll}
(0.142) \quad(0.057) \quad(0.264)
\end{array} \\
& (0.090) \\
& +2.643 \mathrm{Y}+0.216 \mathrm{D}_{2}+\mathrm{u}_{\mathrm{pr}} \\
& (0.957) \quad(0.259) \quad R^{2}=0.673 s_{\mathfrak{u}}=0.103 \mathrm{~d}=1.31 \\
& \text { (15.16) } \mathrm{P}_{\mathrm{br}}=-0.157-0.266 \mathrm{X}_{\mathrm{b}}+0.227 \mathrm{X}_{\mathrm{p}}-0.081 \mathrm{Im}-\mathrm{Ex}_{\mathrm{b}}
\end{aligned}
$$

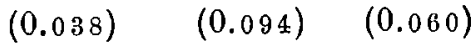

$$
\begin{aligned}
& 0.373 \mathrm{Im}-\mathrm{Ex}_{\mathrm{p}}+3.596 \mathrm{Y}-0.208 \mathrm{D}_{2}+\mathrm{u}_{\mathrm{br}} \\
& \begin{array}{lll}
(0.175) & (0.634) \quad(0.172)
\end{array} \\
& \mathrm{R}^{2}=0.875 \mathrm{~s}_{\mathrm{u}}=0.068 \mathrm{~d}=1.75
\end{aligned}
$$

The same inconsistencies with respect to the coefficients of pork variables are encountered here, too, as in the case of the quarterly model. The coefficients of multiple determination of these demand functions are again higher than those for the semiannual model II.

The test of the noncorrelation of the residuals for the semiannual model II, (table 15.6) gives the same result as in the case of the quarterly model.

\section{Estimates for the block-recursive model}

As was mentioned earlier, the ordinary least squares method (OLS) cannot be applied succesfully - the estimates do not have the required statistical properties - if the function to be estimated includes an explanatory endogenous variable, because then we cannot assume the dis-

$9 \quad 8609-68$ 
turbances $\mathbf{u}$ to be independent of the explanatory endogenous variable. When the two-stage least squares method (TSLS) is used, it is avoided by replacing the explanatory endogenous variables $Y_{i}$ (for example $i=2,3$, $\ldots, \mathrm{k})$ included in the function to be estimated:

$$
Y_{1 t}=a_{1}+\sum_{i=2}^{k} b_{i} Y_{i t}+\sum_{j=1}^{m} c_{j} Z_{j t}+u_{t}
$$

by new variables

$$
\hat{\mathrm{Y}}_{\mathrm{it}}=\mathrm{a}_{\mathrm{il}}^{\prime}+\sum_{j=1}^{\mathrm{n}} \mathrm{c}_{\mathrm{j}}^{\prime} \mathrm{Z}_{\mathrm{jt}}, \quad \mathrm{i}=2,3, \ldots, \mathrm{k} .
$$

Function (16.2) includes all predetermined variables of the model, and its coefficients are obtained by first applying the method of least squares to it. The final estimates of parameters of (16.1) are obtained by applying again. the method of least squares to

$$
\mathrm{Y}_{\mathrm{lt}}=\mathrm{a}_{1}+\sum_{\mathrm{i}=2}^{\mathrm{k}} \mathrm{b}_{\mathrm{i}} \hat{\mathrm{Y}}_{\mathrm{it}}+\sum_{j=1}^{\mathrm{m}} \mathrm{c}_{\mathrm{j}} \mathrm{Z}_{\mathrm{jt}}+\mathrm{u}_{\mathrm{t}} \text {. }
$$

The asymptotic standard errors of the estimates are computed in the same way by using the function (15.3) as in the case of the ordinary least squares. ${ }^{1}$ However, it has to be kept in mind that these errors are not actually the same as those for OLS, because at the second stage of the method the computed values of $\mathrm{Y}$ are used, which means that their variances are different from those of the actual values of $\mathrm{Y}$. This, of course, may have some effect on standard errors.

The following TSLS functions were estimated from quarterly data:

$$
\begin{aligned}
& (16.4)^{2} \\
& \mathrm{Im}-\mathrm{Ex}_{\mathrm{p}}=-2.197+1.138 \mathrm{P}_{\mathrm{pp}}+0.078 \mathrm{D}_{\mathrm{II}}+0.100 \mathrm{D}_{\mathrm{III}} \\
& \begin{array}{lll}
(0.171) & (0.049) \quad(0.048)
\end{array} \\
& +0.009 \mathrm{D}_{\mathrm{IV}}+\mathrm{u}_{\mathrm{imp}}^{\prime} \\
& \text { (0.046) } \quad R^{2}=0.565 \mathrm{~s}_{\mathrm{u}}=0.102 \mathrm{~d}=2.34 \\
& \begin{array}{rr}
(0.130) & (0.054) \quad(0.053) \\
R^{2} \stackrel{(0.052)}{=} 0.436 \quad S_{u}=0.116 \quad d=1.55
\end{array} \\
& \operatorname{Im}-\mathrm{Ex}_{\mathrm{b}}=-0.767+0.485 \mathrm{P}_{\mathrm{bp}}-0.076 \mathrm{D}_{\mathrm{II}}-0.030 \mathrm{D} \mathrm{DII}+0.027 \mathrm{D}_{\mathrm{IV}}+\mathrm{u}_{\mathrm{imb}} \\
& \begin{array}{llll}
(0.165) & (0.084) \quad(0.083) & (0.083)
\end{array} \\
& \mathrm{R}^{2}=0.206 \mathrm{su}=0.184 \mathrm{~d}=0.99
\end{aligned}
$$


(16.5) $\mathrm{Im}-\mathrm{Ex}_{\mathrm{b}}=-1.493+0.904 \mathrm{P}_{\mathrm{bp}}-0.120 \mathrm{D}_{\mathrm{II}}-0.058 \mathrm{D}_{\mathrm{III}}-0.012 \mathrm{D}_{\mathrm{IV}}$ $\begin{array}{llll}(0.175) & (0.072) & (0.070) & (0.070)\end{array}$

$$
+\mathrm{u}_{\mathrm{imb}} \quad \mathrm{R}^{2}=0.438 \mathrm{~s}_{\mathrm{u}}=0.155 \mathrm{~d}=1.20
$$

(16.6) $\mathrm{P}_{\mathrm{pr}}=3.341-0.600 \mathrm{C}_{\mathrm{p}}-0.106 \mathrm{C}_{\mathrm{b}}+1.908 \mathrm{Y}-0.144 \mathrm{D}_{\mathrm{II}}+0.276 \mathrm{D}_{\mathrm{III}}$

$$
\begin{array}{ccc}
(0.131) \quad(0.105) & (0.863) \quad(0.055) \quad(0.091) \\
+0.654 \mathrm{D}_{\mathrm{IV}}+\mathrm{u}_{\mathrm{pr}} & \mathrm{R}^{2}=0.529 \mathrm{~s}_{\mathrm{u}}=0.117 \mathrm{~d}=0.68 \\
(0.151) &
\end{array}
$$

(16.7) $\mathrm{P}_{\mathrm{br}}=0.729-0.719 \mathrm{C}_{\mathrm{b}}+0.047 \mathrm{C}_{\mathrm{p}}+4.995 \mathrm{Y}-0.047 \mathrm{D}_{\mathrm{II}}+0.144 \mathrm{D}_{\mathrm{III}}$

$$
\begin{array}{cl}
\quad(0.090) \quad(0.113) & (0.740) \quad(0.047) \quad(0.078) \\
+0.194 D_{\mathrm{IV}}+\mathrm{u}_{\mathrm{br}} & \mathrm{R}^{2}=0.703 \mathrm{~s}_{\mathrm{u}}=0.100 \cdot \mathrm{d}=1.39 \\
(0.129) & \ddots
\end{array}
$$

(16.8) $\mathrm{M}_{\mathrm{p}}=-0.989+0.343 \mathrm{P}_{\mathrm{pr}}+0.628 \mathrm{~W}-0.420 \mathrm{Im}-\mathrm{Ex}_{\mathrm{p}}+0.033 \mathrm{D}_{\mathrm{lI}}$

$$
\begin{gathered}
(0.327) \quad(0.450) \quad(0.266) \\
+0.055 \mathrm{D}_{\mathrm{III}}+0.014 \mathrm{D}_{\mathrm{IV}}+\mathrm{u}_{\mathrm{mp}}
\end{gathered}
$$$$
(0.030) \quad(0.022)
$$

$$
R^{2}=0.746 \mathrm{~s}_{\mathrm{u}}=0.048 \mathrm{~d}=1.12
$$

$$
\begin{aligned}
& \mathrm{M}_{\mathrm{b}}=-0.913+0.561 \mathrm{P}_{\mathrm{br}}+0.220 \mathrm{~W}-0.639 \mathrm{Im}-\mathrm{Ex}_{\mathrm{b}}-0.100 \mathrm{D}_{\mathrm{II}} \\
& \begin{array}{lll}
(0.160) & (0.213) & (0.154)
\end{array}(0.035) \\
& -0.018 \mathrm{D}_{\mathrm{III}}+0.015 \mathrm{D}_{\mathrm{IV}}+\mathrm{u}_{\mathrm{mb}} \\
& \text { (0.037) (0.034) } \\
& \mathrm{R}^{2}=0.474 \mathrm{~s}_{\mathrm{u}}=0.074 \mathrm{~d}=1.20
\end{aligned}
$$

The $\mathbf{R}^{2}$ rose for all functions as compared with the OLS functions (see also Figures 16.1-16.2). Particularly the increase in $\mathrm{R}^{2}$ for the price margin function for beef was considerable, even though the explanation of the function was still low.

The TSLS estimates differed considerably-from the OLS estimates for the recursive model. For example, the estimates of the coefficients of the producer prices in the Im-Ex functions about doubled. For comparisons, the price flexibilities of the demand functions for both models are given in Table 16.I. The TSLS estimates for the demand for pork are more plausible than the OLS estimates. The TSLS price flexibility with respect to the pork consumption $(-0.826)$ is higher than the corresponding OLS estimate $(-0.418)$ whereas that with respect to the consumption of beef $(-0.177)$ is smaller than the OLS estimate $(-0.355)$ and thus the relation of these 
Table 16.1. Price flexibilities of the quarterly demand functions as obtained by the TSLS and OLS methods

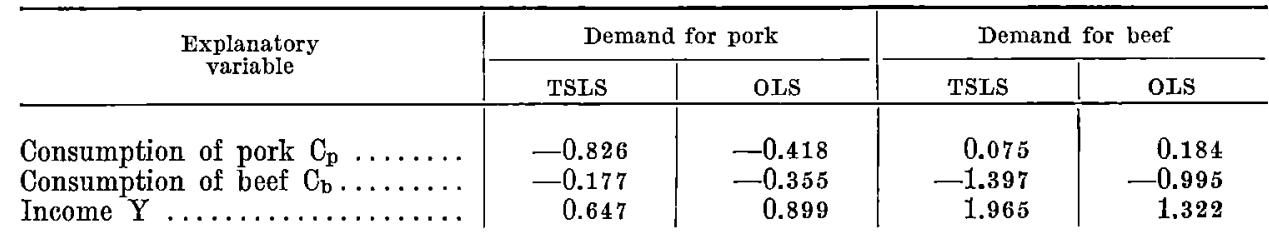

TSLS price flexibility estimates seems more reliable. The TSLS income elasticity is also smaller than the corresponding OLS estimates, which confirms our expectation of the low income elasticity for demand for pork. As compared with the income elasticity obtained by using the ordinary demand function it is still high.

The elasticity of demand for beef with respect to the beef consumption and income rose markedly. The TSLS cross elasticity with respect to pork consumption is close to zero and it is thus quite acceptable even though it is still positive.

The greatest changes in the estimates occured in the price margin functions. All coefficients except that of wages in the price margin for pork rose consederably. At the same time, however, the standard errors of estimates increased so much that none of the estimates of the price margin for pork became statistically significant.

The standard errors of the estimates are, moreover, unreliable (too small) since the residuals are, according to the Durbin-Watson statistics, serially correlated. They are also correlated with each other, as is seen from Table 16.2 where the matrix of the linear correlation coefficients is given. The correlation is caused by the residuals of the Im-Ex functions, the residuals of the other four functions being not correlated with each other. Compared

Table 16.2. The matrix of the linear correlation coefficients of the residuals of the quarterly TSLS model Ia ${ }^{1}$

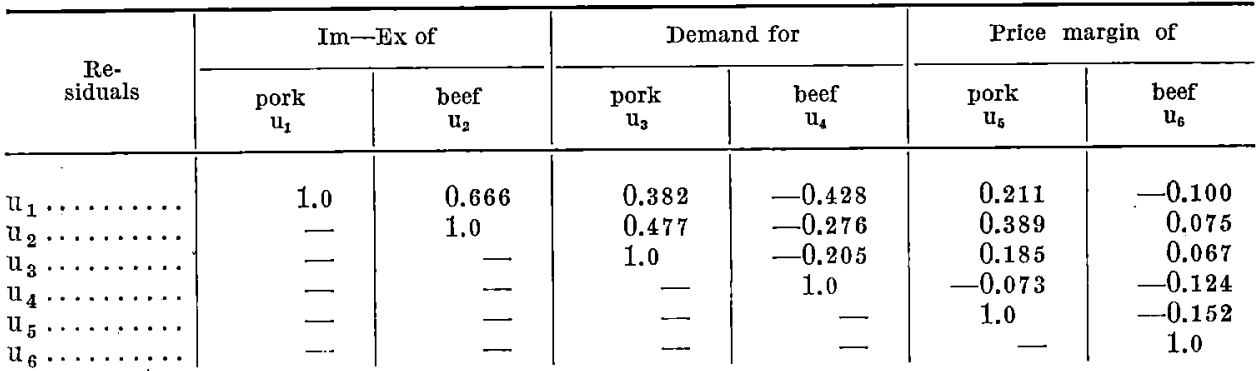

1 For $\mathrm{n}=40 \mathrm{r}$ has to be $\geq 0.31$ at the 95 per cent and $\geq 0.40$ at the 99 per cent confidence level in order to be statistically different from zero. 

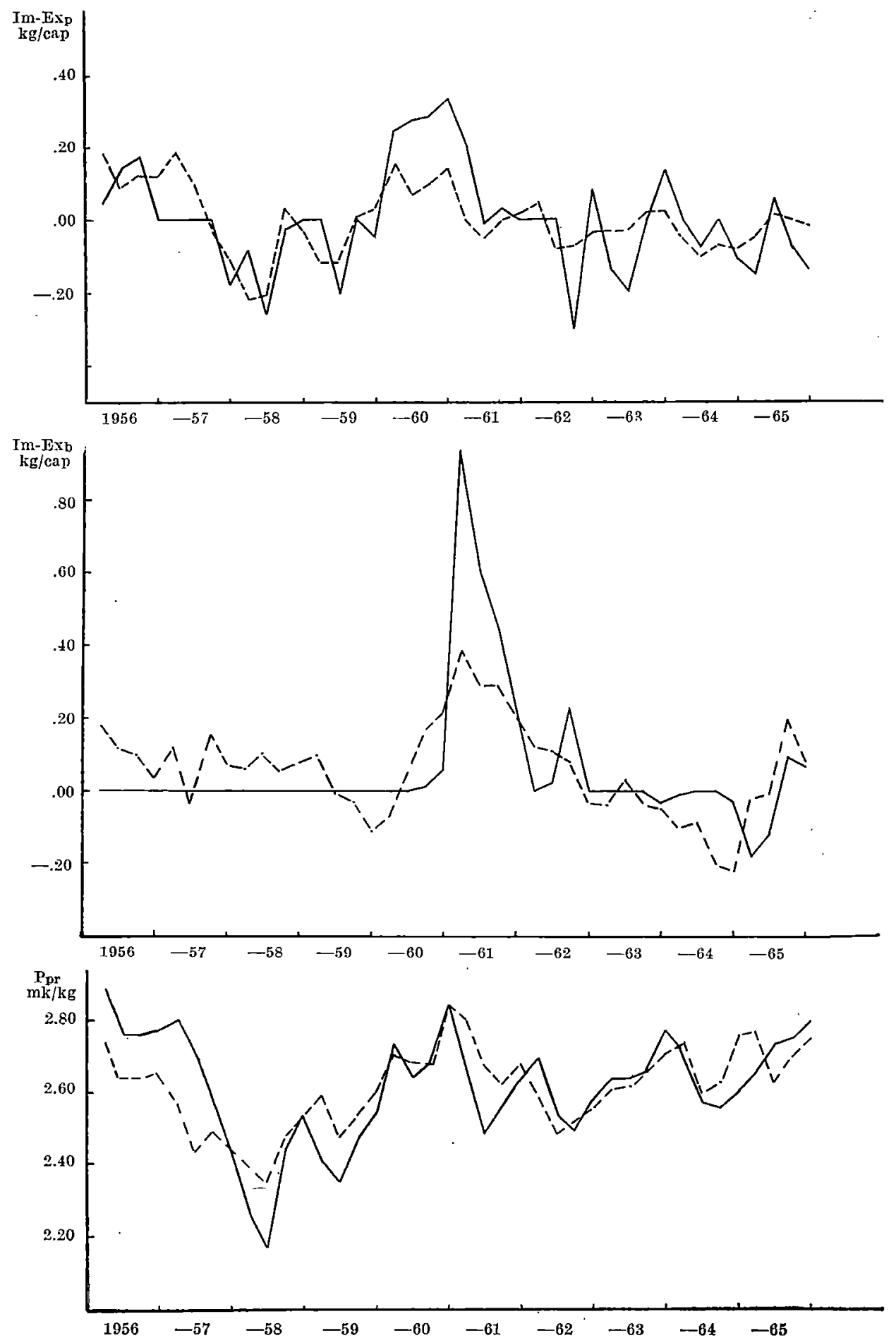

Figure 16.1. The observed values (-) of net imports of pork and beef and of the retail price of pork and the correspondig values $(-\ldots)$ as estimated from functions $(16.4)-(16.6)$. 

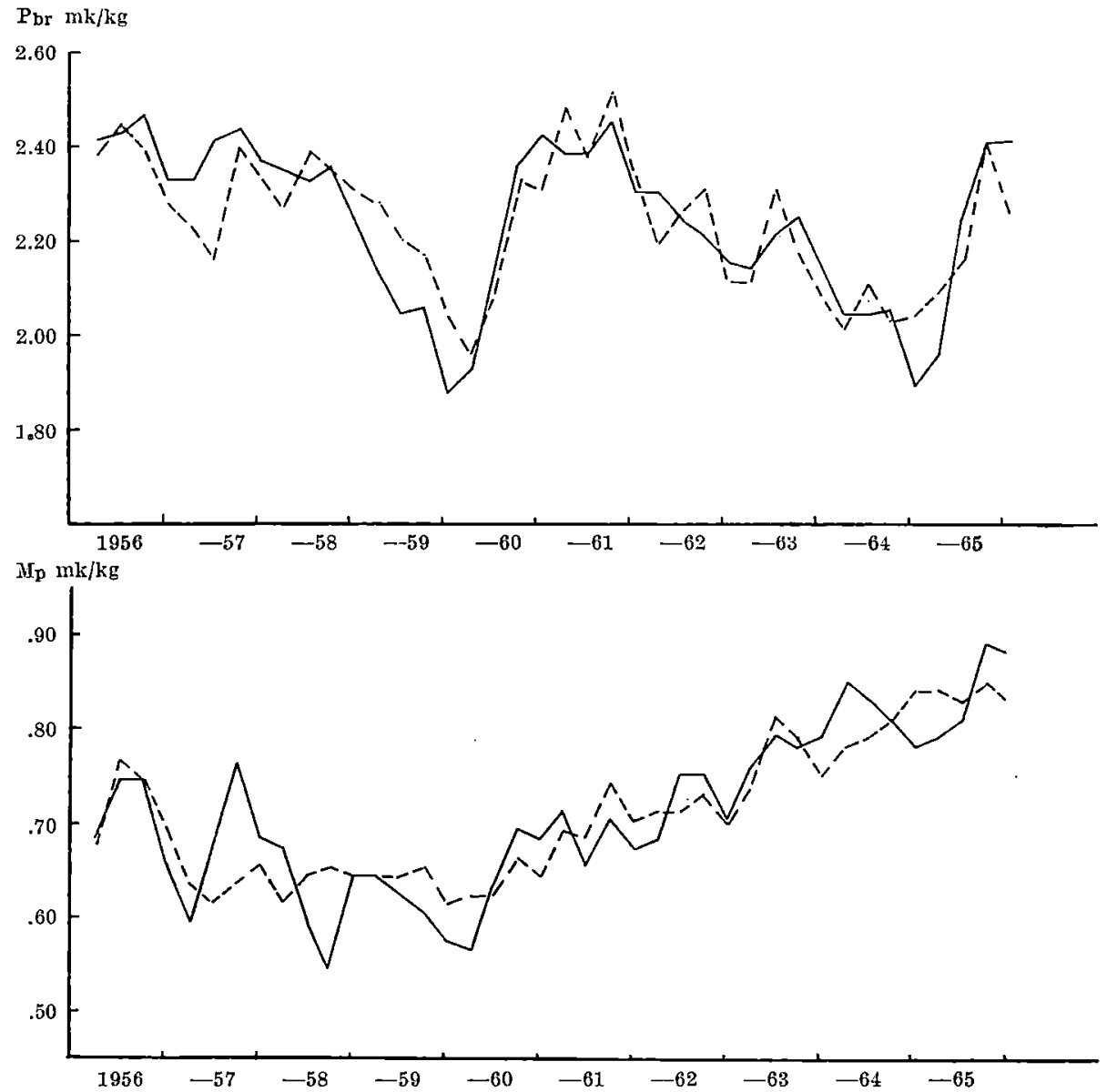
un mathes

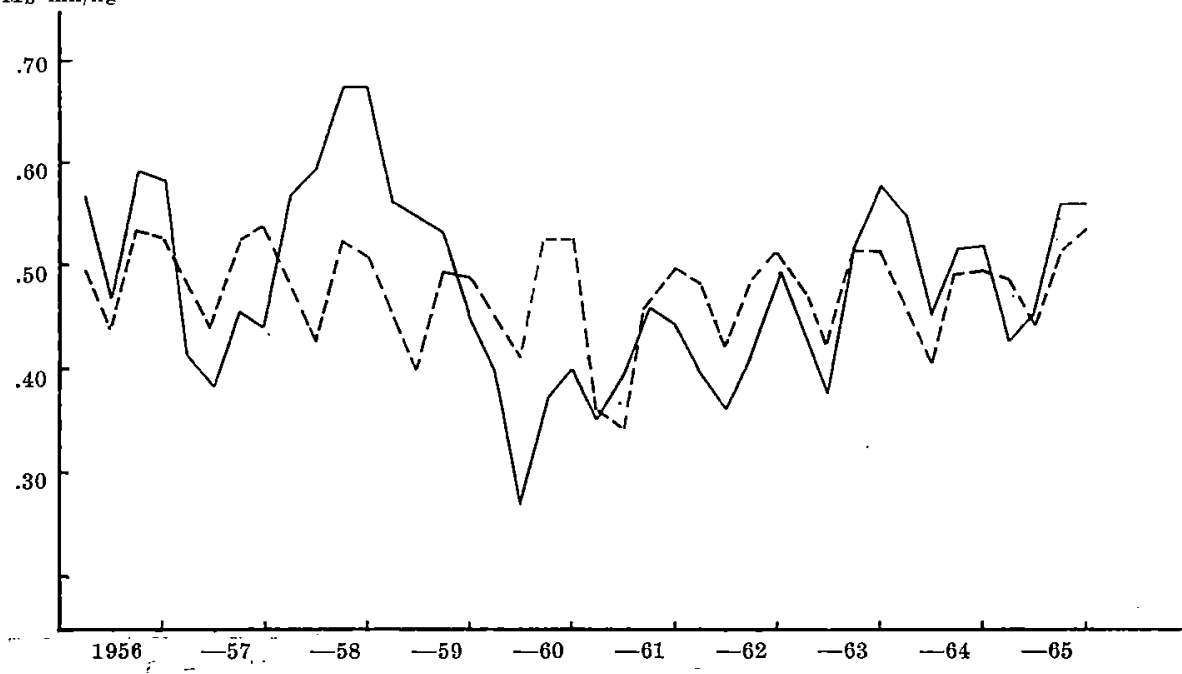

Figure $1 \overline{6} .2$. The observed values (-) of the retail price of beef and of the priee margins of pork and beef and the corresponding values (-..--) as estimated from functions (16.7) - (16.9). 
with the recursive model, the simultaneous model seems to be worse in this respect.

When the semiann ual data was applied the following TSLS functions were estimated: 1

$$
\begin{aligned}
& \text { (16.12) } \operatorname{Im}-\mathrm{Ex}_{\mathrm{p}}=-4.226+2.339 \mathrm{P}_{\mathrm{pp}}+0.026 \mathrm{D}_{2}+\mathrm{u}_{\mathrm{imp}} \\
& (0.300) \quad(0.056) \\
& \mathrm{R}^{2}=0.783 \mathrm{~s}^{\mathrm{u}}=0.124 \mathrm{~d}=2.21 \\
& \text { (16.13) } \mathrm{Im}-\mathrm{Ex}_{\mathrm{b}}=-2.848+1.930 \mathrm{P}_{\mathrm{bp}}+0 \mathrm{D}_{2}+\mathrm{u}_{\mathrm{imb}} \\
& (0.550) \quad(0.139) \\
& \mathrm{R}^{2}=0.420 \mathrm{~s}_{\mathrm{u}}=0.308 \mathrm{~d}=1.90 \\
& \text { (16.14), } \mathrm{P}_{\mathrm{pr}}=3.526-0.355 \mathrm{C}_{\mathrm{p}}-0.067 \mathrm{C}_{\mathrm{b}}+2.128 \mathrm{Y}+0.653 \mathrm{D}_{2}+\mathrm{u}_{\mathrm{pr}} \\
& \begin{array}{llll}
(0.107) \quad(0.076) & (1.259) \quad(0.194)
\end{array} \\
& \mathrm{R}^{2}=0.539 \mathrm{~s}_{\mathrm{u}}=0.114 \mathrm{~d}=1.09 \\
& \text { (16.15) } \mathrm{P}_{\mathrm{br}}=0.554-0.387 \mathrm{C}_{\mathrm{b}}+0.015 \mathrm{C}_{\mathrm{p}}+5.496 \mathrm{Y}+0.221 \mathrm{D}_{2}+\mathrm{u}_{\mathrm{wr}} \\
& \begin{array}{llll}
(0.057) & (0.080) & (0.945) & (0.146)
\end{array} \\
& \mathrm{R}^{2}=0.773 \mathrm{~s}_{\mathrm{u}}=0.085 \mathrm{~d}=1.56 \\
& \text { (16.16) } \mathrm{M}_{\mathrm{p}}=-0.939+0.703 \mathrm{~W}+0.395 \mathrm{P}_{\mathrm{pr}}-0.197 \mathrm{Im}-\mathrm{Ex}_{\mathrm{p}} \\
& (0.431) \quad(0.304) \quad(0.120) \\
& +0.017 \mathrm{D}_{2}+\mathrm{u}_{\mathrm{mp}} \\
& \text { (0.017) } \quad R^{2}=0.846 \mathrm{~s}_{\mathrm{u}}=0.038 \mathrm{~d}=1.98
\end{aligned}
$$

(16.17) $\mathrm{M}_{\mathrm{b}}=-0.980+0.219 \mathrm{~W}+0.569 \mathrm{P}_{\mathrm{br}}-0.328 \mathrm{Im}-\mathrm{Ex}_{\mathrm{b}}$

$$
\begin{array}{rrr}
(0.258) & (0.173) & (0.085) \\
+0.048 \mathrm{D}_{2}+\mathrm{u}_{\mathrm{mb}} & \mathrm{R}^{2}=0.592 \mathrm{~s}_{\mathrm{u}}=0.064 \mathrm{~d}=1.78 \\
(0.029) &
\end{array}
$$

and the identities as previously.

The estimates of the coefficients of the Im-Ex functions about doubled as compared with the quarterly model, and as is seen, $\mathrm{R}^{2}$ rose considerably for both Im-Ex functions.

1 The ordinary least squares estimates of the Im-Ex functions are as follows:

$$
\begin{array}{rrr}
(16.18) & \mathrm{Im}-\mathrm{Ex}_{\mathrm{p}}=-2.348+\underset{(0.302)}{+1.293 \mathrm{P}_{\mathrm{pp}}+\underset{(0.082)}{+0.030 \mathrm{D}_{2}+\mathrm{u}_{\mathrm{imp}}}} & \mathrm{R}^{2}=0.526 \mathrm{~s}_{\mathrm{u}}=0.183 \mathrm{~d}=1.03 \\
(16.19) & \mathrm{Im}-\mathrm{Ex}_{\mathrm{b}}=-1.023+\underset{(0.519)}{0.746 \mathrm{P}_{\mathrm{bp}}+\underset{(0.172)}{0.007 \mathrm{D}_{2}}+\mathrm{u}_{\mathrm{imb}}} & \mathrm{R}^{2}=0.109 \mathrm{~s}_{\mathrm{u}}=0.382 \mathrm{~d}:=1.60
\end{array}
$$


Table 16.3. Price flexibilities of the semiannual demand functions as obtained by the TSLS and OLS methods

\begin{tabular}{c|r|r|r|r}
\hline \multirow{2}{*}{$\begin{array}{c}\text { Explanatory } \\
\text { variable }\end{array}$} & \multicolumn{2}{|c|}{ Demand for pork } & \multicolumn{2}{c}{ Demand for beef } \\
\cline { 2 - 5 } \cline { 2 - 4 } & TSLS & OLS & TSLS & OLS \\
\hline Consumption of pork $\mathrm{C}_{\mathrm{p}} \ldots \ldots \ldots$ & -0.974 & -0.746 & 0.047 & 0.108 \\
Consumption of beef $\mathrm{C}_{\mathrm{b}} \ldots \ldots \ldots$ & -0.224 & -0.428 & -1.505 & -1.109 \\
Income $\mathrm{Y} \ldots \ldots \ldots$ & 0.721 & 1.032 & 2.162 & 1.528
\end{tabular}

The resulte with respect to the demand functions are similar to those for the quarterly model (see Table 16.3). The TSLS estimates are again a little larger than the OLS estimates. The semiannual estimates are also larger than the quarterly estimates, which can be expected since the time period (observation period) is larger and thus they are "longer run» estimates compared with the quarterly (short run) estimates. Long run elasticities are usually assumed to be larger than the short run elasticities. For example, the Nerlove model implies so. Very short run (e.g. weekly) elasticities may, however, be larger than the long run estimates, because consumers may delay their purchases for a while.

The $R^{2}$ for price margin functions for beef $(0.592)$ is now rather acceptable. In this case the simultaneous estimation gave the best result, for the $R^{2}$ for the OLS method was only 0.263. The price margin function for pork is good in that sense, too, but as often occurs, the intercorrelation which is a result of the TSLS estimation method, makes the standard errors of the estimates large.

Even though the TSLS estimates of the regression coefficients seem rather good, their superiority over the OLS estimates is disturbed by the fact that the residual analysis shows their residuals to be more correlated with each other than the corresponding OLS residuals as Tables 16.4 and 15.6 indicate.

Table 16.4. The matrix of the linear correlation coefficients of the residuals for the semiannual TSLS model Ta 1

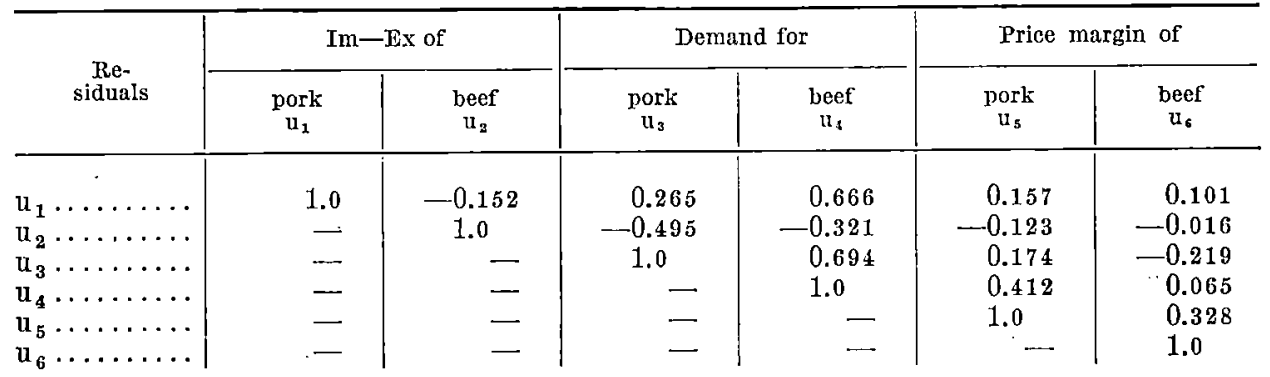

I For $\mathrm{n}=20 \mathrm{r}$ has to be $\geq 0.44$ at the 95 per cent and $\geq 0.56$ at the 99 per cent confidence lecel in order to be statistically different from zero. 


\section{Ordinary demand functions}

For comparisons, the ordinary demand functions were also estimated assuming the per capita consumption as the dependent variable and the retail prices and the income level as the independent variables. The estimates are given in Tables 17.1 and 17.2.

The fit of these regression lines is much better than that of the demand functions in the models presented earlier (see also Figures 17.1 and 17.2). The elasticities are rather plausible, except the cross elasticity of the demand for beef with respect to the retail price of pork $\left(\mathrm{P}_{\mathrm{pr}}\right)$, which is, consistently with the previous results, wrong by its sign. Taking into account the large standard error it only confirms the assumption made earlier that pork is weak if no substitute for beef. ${ }^{1}$

Table 17.1. The demand for pork. A linear quarterly function, the per capita consumption of pork as the dependent variable. Retail prices and income are deflated by the cost of living index

\begin{tabular}{|c|c|c|c|c|c|}
\hline $\begin{array}{c}\text { Explanatory } \\
\text { variable }\end{array}$ & $\begin{array}{l}\text { Reg. } \\
\text { coeff. } \\
\text { b }\end{array}$ & $\begin{array}{c}\text { Stand. } \\
\text { error } \\
\mathrm{s}_{\mathbf{b}}\end{array}$ & $\underset{t}{\text { Student's }}$ & $\begin{array}{c}\text { Elasti- } \\
\text { city } \\
b^{*}\end{array}$ & $\begin{array}{l}\text { Loss of } \\
\text { sum of } \\
\text { squares }\end{array}$ \\
\hline Retail price of pork $\mathrm{P}_{\mathrm{pr}}$. & -0.602 & 0.203 & 2.97 & -0.437 & 0.231 \\
\hline Retail price of beef $\mathrm{P}_{\mathrm{br}} \ldots \ldots \ldots$ & 0.403 & 0.178 & 2.27 & 0.252 & 0.135 \\
\hline Income $Y \ldots \ldots \ldots \ldots \ldots$ & 1.088 & 0.452 & 2.40 & 0.268 & 0.152 \\
\hline Seasonal $\mathrm{D}_{\mathrm{II}}$ & -0.128 & 0.078 & 1.65 & — & 0.072 \\
\hline $\bar{D}_{\text {III }}$ & 0.474 & 0.079 & 6.03 & $\ldots$ & 0.956 \\
\hline $\mathrm{D}_{\text {IV }} \ldots$ & 1.034 & 0.073 & 14.21 & - & 5.315 \\
\hline
\end{tabular}

$\mathrm{R}^{2}=0.905 \mathrm{~S}_{\mathrm{u}}=0.162 \mathrm{~d}=1.49 \mathrm{a}=2.948 \mathrm{SS}_{\mathrm{y}}=9.141$

Table 17.2. The demand for beef. A linear quarterly function, the per capita consumption of pork as the dependent variable. Retail prices and income are deflated by the cost of living index

\begin{tabular}{|c|c|c|c|c|c|}
\hline $\begin{array}{c}\text { Explanatory } \\
\text { variable }\end{array}$ & $\begin{array}{l}\text { Reg. } \\
\text { coeff. } \\
\text { b }\end{array}$ & $\begin{array}{c}\text { Stand. } \\
\text { error } \\
\mathrm{s}_{\mathrm{b}}\end{array}$ & $\underset{t}{\text { Student's }}$ & $\begin{array}{c}\text { Elasti- } \\
\text { city } \\
\text { b }^{*}\end{array}$ & $\begin{array}{l}\text { Loss of } \\
\text { sum of } \\
\text { squares }\end{array}$ \\
\hline Retail price of beef $\mathrm{P}_{\mathrm{br}} \ldots \ldots \ldots$ & -1.058 & 0.178 & 5.89 & -0.544 & 0.933 \\
\hline Retail price of pork $\mathrm{P}_{\mathrm{pr}} \ldots \ldots \ldots$ & -0.062 & 0.205 & 0.30 & -0.037 & 0.002 \\
\hline Income $Y \ldots \ldots \ldots \ldots \ldots$ & 7.221 & 0.458 & 15.78 & 1.462 & 6.707 \\
\hline Seasonal $D_{\text {II }} \quad \ldots \ldots \ldots \ldots \ldots \ldots$ & -0.095 & 0.078 & 1.21 & - & 0.039 \\
\hline DIII $\ldots \ldots$ & 0.193 & 0.079 & 2.42 & 一 & 0.158 \\
\hline Div $\ldots \ldots \ldots \ldots \ldots$ & 0.332 & 0.074 & 4.51 & - & 0.549 \\
\hline
\end{tabular}

$\mathrm{R}^{2}=0.937 \mathrm{~S}_{\mathrm{u}}=0.164 \mathrm{~d}=1.76 \mathrm{a}=0.414 \mathrm{SS}_{\mathrm{y}}=14.152$

1 Some estimates from earlier studies may be mentioned here: the income elasticities obtained from budget studies, 0.342 (double-log function) and 0.361 (semi-log function) for beef. KaARLE HTO: Tulotason vaikutuksesta... op. cit., p. 25. According to SANDELIN, the price elasticity of the demand for beef is from -0.3 to -1.0 , depending on the real price level. SANDELIN: op. cit., p. 37 .

$10 \quad 8609-68$ 


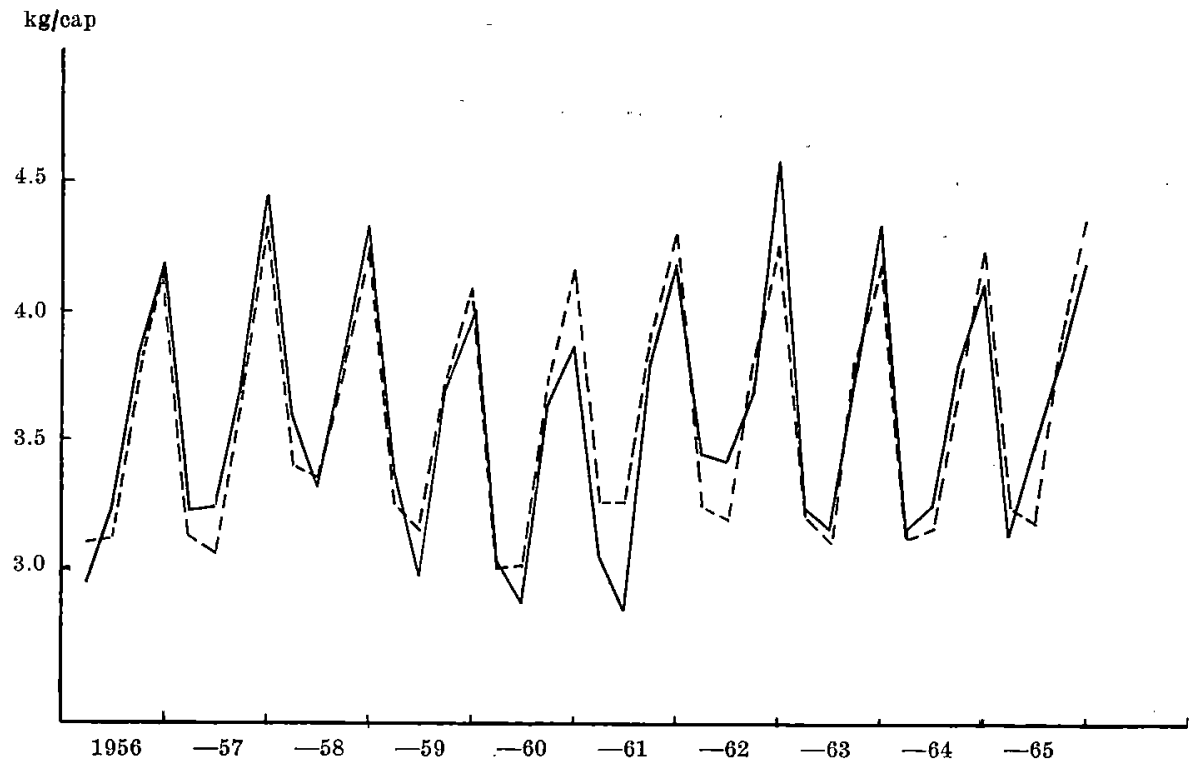

Figure 17.1. The observed values (- $\longrightarrow$ ) of the per capita consumption of pork and the corresponding values (-..-) as estimated from function (17.1) ('Table 17.1).

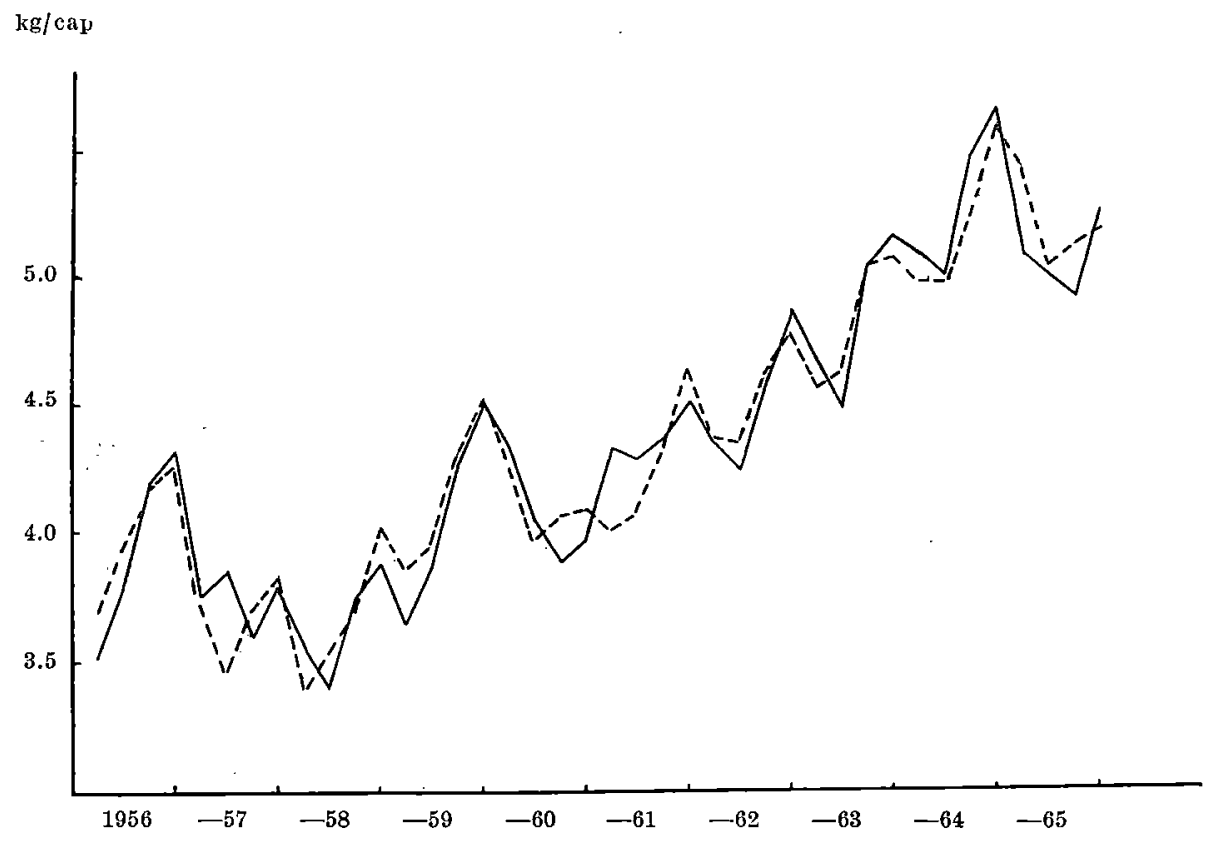

Figure 17. 2. The observed values $(\longrightarrow)$ of the per captia consumption of beef and the corresponding values (-..-) as estimated from function (17.2) (Table 17.2). 
Table 17.3. The demand for pork. A linear semiannual function, the per capita consumption of pork as the dependent variable. Retail prices and income are deflated by the cost of living index

\begin{tabular}{|c|c|c|c|c|c|}
\hline$: \quad \underset{\text { variable }}{\text { Explanatory }}$ & $\begin{array}{c}\text { Reg. } \\
\text { coeff. } \\
\text { b }\end{array}$ & $\begin{array}{l}\text { Stand. } \\
\text { error } \\
\mathbf{s}_{\mathbf{b}}\end{array}$ & $\underset{t}{\text { student's }}$ & $\begin{array}{c}\text { Elasti- } \\
\text { city } \\
b^{*}\end{array}$ & $\begin{array}{l}\text { Loss of } \\
\text { sum of } \\
\text { squares }\end{array}$ \\
\hline Retail price of pork $\mathrm{P}_{\mathrm{pr}}$. & -1.215 & 0.433 & 2.80 & -0.443 & 0.437 \\
\hline Retail price of beef $\mathrm{P}_{\mathrm{br}} \ldots \ldots \ldots$ & 0.681 & 0.381 & 1.79 & 0.214 & 0.177 \\
\hline Income $Y \ldots \ldots \ldots \ldots \ldots \ldots$ & 1.964 & 0.944 & 2.08 & 0.242 & 0.240 \\
\hline Seasonal $\mathrm{D}_{2} \ldots \ldots \ldots \ldots \ldots$ & 1.691 & 0.106 & 15.90 & - & 14.047 \\
\hline
\end{tabular}

$\mathbf{R}^{2}=0.947 \mathrm{~s}_{\mathfrak{u}}=0.236 \mathrm{~d}=0.96 \mathrm{a}=6.218 \mathrm{SS}_{\mathrm{y}}=15.798$

Table 17.4. The demand for beef. A linear semiannual function, the per capita consumption of beef as the dependent variable. Retail prices and income are deflated by the cost of living index

\begin{tabular}{|c|c|c|c|c|c|}
\hline$\underset{\text { variable }}{\text { Explanatory }}$ & $\begin{array}{l}\text { Reg. } \\
\text { coeff. } \\
\text { b }\end{array}$ & $\begin{array}{l}\text { Stand. } \\
\text { error } \\
\text { s }_{\mathbf{b}}\end{array}$ & $\underset{t}{\text { Student's }}$ & $\begin{array}{c}\text { Elasti- } \\
\text { city } \\
b^{*}\end{array}$ & $\begin{array}{l}\text { Loss of } \\
\text { sum of } \\
\text { squares }\end{array}$ \\
\hline Retail price of beef $\mathrm{P}_{\mathrm{br}} \ldots$ & -2.272 & 0.516 & 5.01 & -0.585 & 1.975 \\
\hline Retail price of pork $\mathrm{P}_{\mathbf{p r}}$. . & -0.145 & 0.454 & 0.28 & -0.043 & 0.006 \\
\hline Income $Y \ldots \ldots \ldots \ldots$ & 14.524 & 1.124 & 12.92 & 1.470 & 13.147 \\
\hline Seasonal $\mathrm{D}_{2} \ldots \ldots \ldots \ldots \ldots \ldots$ & 0.626 & 0.127 & 4.95 & - & 1.926 \\
\hline
\end{tabular}

$\mathrm{R}^{2}=0.957 \mathrm{~s}_{\mathrm{u}}=0.281 \mathrm{~d}=2.33 \mathrm{a}=1.062 \mathrm{SS}_{\mathrm{y}}=27.574$

As Tables 17.3 and 17.4 show, the semian $n$ u a l estimates are practically the same as the quarterly estimates.

When the price of processed meat was included in the ordinary demand functions, the following quarterly functions were estimated (the elasticities are given in the brackets):

$$
\begin{aligned}
& (17.5), \mathrm{C}_{\mathrm{p}}=3.581-0.729 \mathrm{P}_{\mathrm{pr}}+0.450 \mathrm{P}_{\mathrm{br}}-0.679 \mathrm{P}_{\mathrm{s}}+1.491 \mathrm{Y}-0.154 \mathrm{D}_{\mathrm{II}} \\
& \begin{array}{lllll}
(0.210) & (0.175) & (0.391) & (0.497) & (0.077)
\end{array} \\
& \text { [-0.529] [0.282]. [-0.210] [0.367] } \\
& +0.456 \mathrm{D}_{\mathrm{III}}+1.043 \mathrm{D}_{\mathrm{IV}}+\mathrm{u}_{\mathrm{ep}} \\
& (0.077) \quad(0.071) \\
& \mathrm{R}^{2}=0.913 \mathrm{~s}_{\mathrm{u}}=0.158 \mathrm{~d}=1.71 \\
& \mathrm{C}_{\mathrm{b}}=-0.279+0.077 \mathrm{P}_{\mathrm{pr}}-1.109 \mathrm{P}_{\mathrm{br}}+0.742 \mathrm{P}_{\mathrm{s}}+6.781 \mathrm{Y} \\
& \begin{array}{llll}
(0.211) & (0.175) & (0.392) & (0.499)
\end{array} \\
& \text { [0.046] [-0.571] [0.189] [1.373] } \\
& -0.067 \mathrm{D}_{\mathrm{II}}+0.216 \mathrm{D}_{\mathrm{III}}+0.322 \mathrm{D}_{\mathrm{IV}}+\mathrm{u}_{\mathrm{cb}} \\
& \begin{array}{lll}
(0.077) & (0.077) \quad(0.071)
\end{array} \\
& \mathrm{R}^{2}=0.946 \mathrm{~s}_{\mathrm{u}}=0.158 \mathrm{~d}=1.90
\end{aligned}
$$


The dependent variables refer to the total consumption of fresh and processed pork or beef. The negative sign of the coefficient of $P_{s}$ in (17.5) implies that an increase in the price of processed meat causes a decrease in the total consumption, since the amount of pork consumed in the form of processed meat decreases. The positive sign of the coefficient of $P_{s}$ in (17.6) implies, on the other hand, that fresh beef and processed meat are substitutes. It is difficult to figure out how plausible this result is. We should have separate demand functions for fresh and processed meat to clear out their substitution effects. The lack of data prevents, however, that estimation.

As to the other estimates, they are all consistent. Even the cross elasticity of the demand for beef with respect to the pork price is consistent by its sign, although it is practically zero and statistically not significant.

These ordinary demand functions would seem to suggest that they are a better approach for determining the demand relationships than the demand functions with the retail price as the dependent variable. The high correlation of the ordinary demand functions may, however, be a result of the fact that the variance of the per capita consumption is larger than that of the retail price. Much of the variation in the per capita consumption of pork is due to the large seasonal variation and so the high $\mathrm{R}^{2}$ for pork is partly nominal.

\section{Evaluation of the estimated models}

We have presented several estimates so far and also compared the estimates obtained by using different estimation methods to each other. Some comments on their "goodness" were already made when the OLS and TSLS estimates of the coefficients of the demand functions were compared with each other. Then an uncertain conclusion was made that the simultaneous model would seem to give more reliable estimates than the recursive model, whose estimates were obtained by using the ordinary least squares method. The ability of the simultaneous model to explain variation in the dependent variables was generally better than that of the recursive model.

To one point in our model we have not paid any attention so far, even though it was thought to be the most important object of application of the model. This is the producer price. Because the "producer price function" is an identity in our model, there was no need to estimate it and therefore no coefficient of multiple determination was obtained for it. We can, however, compute the estimates for the producer prices by using the estimated values of the retail prices and price margins. The residuals, i.e., the deviation of these estimates from the actual values, are given in Table 18.1. In addition to OLS and TSLS estimates, another two residuals are given: those for the demand functions at the producer level (DFP) and those for indirect demand functions (ILS) derived from the ordinary demand functions. 
Table 18.1. The observed values of the producer prices for pork and beef, as deflated by the cost of living index; the residuals for two-stage least squares (TSLS), ordinary least squares (OLS), demand functions at the producer level (DFP), and indirect least squares (ILS); and the sums of squares of residuals $\left(\mathbf{S S}_{\mathrm{u}}\right)$

\begin{tabular}{|c|c|c|c|c|c|c|c|c|c|c|c|}
\hline & \multirow{3}{*}{$\begin{array}{c}\text { Year } \\
\text { Quarter }\end{array}$} & \multicolumn{5}{|c|}{ Pork } & \multicolumn{5}{|c|}{ Beef. } \\
\hline & & \multirow{2}{*}{$\begin{array}{l}\text { Ob- } \\
\text { served } \\
\text { values }\end{array}$} & \multicolumn{4}{|c|}{ Residuals for } & \multirow{2}{*}{$\begin{array}{l}\text { Ob- } \\
\text { served } \\
\text { values }\end{array}$} & \multicolumn{4}{|c|}{ Residuals for } \\
\hline & & & TSLS & OLS & DFP & ILS & & TSLS & OLS & DFP & ILS \\
\hline \multirow[t]{4}{*}{1956} & I & 2.20 & .14 & .12 & .11 & -.37 & 1.84 & -.05 & -.06 & -.03 & -.22 \\
\hline & II & & .14 & .15 & .04 & .08 & & .01 & -.03 & -.06 & -.17 \\
\hline & & 2.0 & .12 & .15 & .04 & .16 & & .03 & -.01 & -.04 & 一.08 \\
\hline & & 2.10 & .15 & .14 & .14 & .03 & 1.74 & .01 & .00 & .02 & -.04 \\
\hline \multirow[t]{4}{*}{1957} & I & 2.21 & .28 & .26 & .26 & .26 & 1.93 & .16 & .13 & .16 & .09 \\
\hline & & & .22 & .28 & .23 & .5 & & .30 & .30 & .29 & .41 \\
\hline & & 1.81 & -.04 & -.09 & -.07 & -.13 & 1.98 & .09 & .05 & .09 & -.03 \\
\hline & IV & 1.74 & -.04 & $\cdots .15$ & -.04 & .13 & 1.93 & .18 & .12 & .17 & .08 \\
\hline \multirow[t]{4}{*}{1958} & I & 1.58 & -.18 & -.26 & -.20 & .27 & 1.77 & .05 & -.03 & .01 & .00 \\
\hline & & 1.57 & -.13 & -.27 & -.11 & -.11 & & -.17 & -.23 & -.14 & -.27 \\
\hline & III & 1.89 & .08 & .06 & .06 & .16 & 1.68 & -.12 & -.16 & -.12 & -.15 \\
\hline & IV & 1.88 & .00 & -.05 &.- .03 & .06 & 1.57 & -.19 & -.24 & -.21 & -.28 \\
\hline \multirow[t]{4}{*}{1959} & I & 1.76 & -.18 & -.23 & -.20 & -.29 & 1.59 & -.19 & -.24 & -.19 & -.29 \\
\hline & II & 1.71 & -.11 & -.15 & -.05 & -.30 & & -.16 & -.17 & -.08 & -.11 \\
\hline & III & 1.86 & -.01 & 一.02 & .01 & .02 & 1.52 & -.15 & -.18 & 一. & -.07 \\
\hline & IV & 1.96 & -.01 & .04 & .05 & -.04 & 1.41 & -.14 & -.13 & -.07 & .03 \\
\hline \multirow[t]{4}{*}{1960} & I & 2. & .10 & .24 & .08 & .17 & 1.52 & -.04 & -.04 & -.05 & .11 \\
\hline & & & -.06 & .08 & -.09 & -.22 & & .11 & .14 & .10 & .21 \\
\hline & III & 1.99 & 一.01 & .05 & -.09 & -.16 & & .1 & .1 &.$c$ & .02 \\
\hline & IV. & 2.15 & -.04 & .03 & -.10 & -.54 & 2.02 & .13 & .18 & .11 & .04 \\
\hline \multirow[t]{4}{*}{1961} & I & 1.94 & -.15 & -.04 & 一.01 & $\ldots .17$ & & -.03 & .26 & -.04 & .30 \\
\hline & & 1.8 & -.17 & -.14 & -.04 & -.5 & 2.00 & -.07 & .16 & .0 & .18 \\
\hline & III & 1.84 & -.03 & -.05 & .02 & -.0 & & -.01 & .10 &.- & .0 \\
\hline & IV & 1.95 & -.01 & -.06 & .02 & -.20 & 1.86 & -.03 & .05 & -.01 & 一.09 \\
\hline \multirow[t]{4}{*}{1962} & $\mathrm{I}$ & & .14 & & & & & .1 & & .11 & .05 \\
\hline & & & .01 & -.03 & -.03 & & & .01 & -.03 & 一.04 & -.08 \\
\hline & III & 1.73 & -.02 & -.09 & .08 & -.08 & & .02 & .07 & .11 & -.14 \\
\hline & & 1.87 & .03 & .06 & .00 & .57 & 1.66 & .05 & .01 & -.02 & .09 \\
\hline \multirow[t]{4}{*}{1963} & I & 1.8 & .01 & -.02 & .03 & & & .11 & & .12 & .15 \\
\hline & II & & .05 & -.01 & .0 & $-.1 \varepsilon$ & & -.01 & -.03 &. & 一.09 \\
\hline & III & & .01 & .04 & & .0 & & .06 & & & .11 \\
\hline & IV & 1.96 & .02 & .08 & -.01 & .26 & 1.56 & -.05 & -.06 & 一.09 & -.02 \\
\hline \multirow[t]{4}{*}{1964} & $\mathrm{I}$ & 1.85 & -.09 & -.04 & -.08 & 一. 01 & 1.50 & -.06 & -.05 & -.05 & .04 \\
\hline & II & & -.07 & -.06 & -.05 & .06 & & -.09 & -.11 & -.08 & -.04 \\
\hline & III & 1.7 & -.07 & .01 & 一. 0 & .27 & & .04 & .02 & .03 & .22 \\
\hline & IV & 1.80 & -.10 & -.06 & -.06 & -.09 & 1.38 & -.08 & -.08 & -.04 & .05 \\
\hline \multirow[t]{5}{*}{1965} & & 1.85 & -.06 & -.14 & -.08 & -.34 & 1.55 & -.09 & -.16 & -.05 &.- .24 \\
\hline & II & 1.92 & .14 & .14 & .05 & & & .04 & 一.03 & 一.03 & -.07 \\
\hline & III & 1.84 & .01 & -.07 & -.01 & -.19 & & -.06 & -.06 & -.06 & -.21 \\
\hline & & 1.90 & .00 & -.07 & .02 & --.22 & 1.86 & .11 & .15 & .14 & .07 \\
\hline & & -1 & 44.95 & 66.12 & 34.39 & 262.44 & -1 & 48.61 & 67.87 & 41.25 & 97.46 \\
\hline
\end{tabular}


The residuals of the demand functions at the producer level are computed from the following functions:

$$
\begin{aligned}
& \mathrm{P}_{\mathrm{pp}}=2.497-0.287 \mathrm{X}_{\mathrm{p}}-0.122 \mathrm{X}_{\mathrm{b}}+0.279 \mathrm{Im}-\mathrm{Ex}_{\mathrm{p}}-0.256 \mathrm{Im}-\mathrm{Ex}_{\mathrm{b}} \\
& \begin{array}{llll}
(0.106) & (0.075) & (0.178) & (0.117)
\end{array} \\
& -0.115 \mathrm{D}_{\mathrm{II}}+0.083 \mathrm{D}_{\mathrm{III}}+0.323 \mathrm{D}_{\mathrm{IV}}+\mathrm{u}_{\mathrm{pp}} \\
& (0.050) \quad(0.077) \quad(0.124) \\
& \mathrm{R}^{2}=0.609 \mathrm{~s}_{\mathrm{u}}=0.106 \mathrm{~d}=\mathbb{1} .06
\end{aligned}
$$

$$
\begin{gathered}
\mathrm{P}_{\mathrm{bp}}=0.400-0.464 \mathrm{X}_{\mathrm{b}}+0.153 \mathrm{X}_{\mathrm{p}}-0.034 \mathrm{Im}-\mathrm{Ex}_{\mathrm{b}}+0.415 \mathrm{Im}-\mathrm{Ex}_{\mathrm{p}} \\
(0.083)(0.116)(0.128) \\
+0.069 \mathrm{D}_{\mathrm{II}}+0.019 \mathrm{D}_{\mathrm{III}}-0.027 \mathrm{D}_{\mathrm{IV}}+\mathrm{u}_{\mathrm{bp}} \\
(0.055) \quad(0.085) \quad(0.136) \\
\mathrm{R}^{2}=0.694 \mathrm{~s}_{\mathrm{u}}=0.116 \mathrm{~d}=1.00
\end{gathered}
$$

As is seen, there are the same inconsistencies with respect to the signs of the estimates in these functions as earlier. We can mention in this connection that the demand functions assuming the producer prices as the dependent variables and the consumptions and income as the explanatory variables were consistent with respect to all estimates, but the coefficients of multiple determination were only 0.316 and 0.461 .

The indirect demand functions are obtained by solving the ordinary demand functions (17.1) and (17.2) for the retail prices (the elasticities are given in brackets):

$$
\begin{aligned}
\mathrm{P}_{\mathrm{pr}}= & 4.967-1.599 \mathrm{C}_{\mathrm{p}}-0.609 \mathrm{C}_{\mathrm{b}}+6.140 \mathrm{Y}-0.263 \mathrm{D}_{\mathrm{II}}+0.875 \mathrm{D}_{\mathrm{III}} \\
& {[-2.201][-1.020] \quad[2.081] } \\
& +1.855 \mathrm{D}_{\mathrm{IV}}
\end{aligned}
$$

$$
\begin{gathered}
\mathrm{P}_{\mathrm{br}}=0.100+0.094 \mathrm{C}_{\mathrm{p}}-0.910 \mathrm{C}_{\mathrm{b}}+6.467 \mathrm{Y}-0.074 \mathrm{D}_{\mathrm{II}}+0.130 \mathrm{D}_{\mathrm{III}} \\
\quad[0.150][-1.767] \quad[2.544] \\
+0.205 \mathrm{D}_{\mathrm{IV}}
\end{gathered}
$$

Since the price elasticities in functions (17.1) and (17.2) were below one, the price flexibilities are now clearly above one. Thus there is a disagreement between the estimates obtained by using different dependent variable: both methods gave price flexibilities and elasticities which were less than unity, even though one should be below and another above. It is difficult to say which one gives wrong estimates or whether both are wrong. If we accept the general belief that the price elasticities are below one, then the price flexibil- 
ities of pork obtained for both models, simultaneous and recursive, are underestimated, since they should be above one. In this respect, the price flexibilities for beef are correct.

Table 18.1. shows that the ILS estimates deviate from the actual values more than any other estimates, and thus the high $\mathrm{R}^{2}$ of the ordinary demand functions are not so good as might be believed. As to the other residuals, it can be seen that the direct way to estimate the producer price, i.e., to use the demand function at the producer level, gives the best result, even though the TSLS estimates do not differ very much in this respect. Moreover, it can be seen that the residuals for each method are smaller for the latter part of the sample period, this being obviously due to a more uncertain data for the beginning of the research period. 


\section{SUMMARY}

The purpose of this study was to derive a total model which would explain the supply and demand (or price formation) of pork and beef in Finland. An incentive for it was the need for quantative studies, which might be employed for price policy purposes regarding the setting and attainment of the socalled target prices for pork and beef. The target price system was described briefly in Chapter 1. As an introduction to the data available for the study, the movements of production, consumption and prices of the products under consideration were briefly discussed and illustrated by figures in Chapter 4 .

In Part II the market structure of pork and beef was put in the form of structural functions, which were also illustrated by a diagram presented in Figure 5.1. There were five stages in the model: supply, imports and exports, demand (retail price), price margin, and producer price. (1) The supply function of pork was defined with (a) the total production or (b) the marketed quantity as the dependent variable, and the producer price of pork, the producer price of potatoes, the price of feed, and a trend variable as the explanatory variables. The supply function for beef was defined with (a) the total production or (b) the marketed quantity as the dependent variable, and the number of cows, hay yield, lagged hay yield, trend variable, and the producer price of beef lagged one and two years as the explanatory variables. (2) Two types of functions explaining imports and exports were applied: net imports (imports minus exports) was the dependent variable in both functions, and (a) producer price or (b) production and income were the explanatory variables. (3) The demand functions explaining the formation of retail price were defined with the per eapita consumption of both products and disposable income as the explanatory variables. Here another alternative was also applied, where the per capita production and net imports of both products, taken separately, plus disposable income were the explananatory variables. (4) The price margin functions included the price margin (the difference between retail and producer price) as the dependent variable and the wage index for commerce, retail price, and the per capita net imports as the explanatory variables. (5) The producer price was defined as the difference between retail price and price margin, i.e., as an identity. 
In Part III the nature of the multi-equation models, which were formed from the functions derived in Part II, was examined. The first problem to be solved concerned the interdependence of the demand and supply functions. The conclusion was reached that even though there may be a slight dependence between demand and supply, from the estimation point of view they have to be treated separately, since the dependence of the retail price on the quantity supplied is so dominating that it is difficult, if not impossible, to statistically estimate the dependence of supply on price. This interdependence allowed the estimation of the parameters of the supply functions by the method of least squares.

The latter part of the models, which consisted of 6 equations to be estimated (the price formation part of the models), formed another research object regarding the nature of the models. There, the net imports functions played a central role. If a function whose explanatory variable is the producer price alone is included in the model, the price formation part, model Ia, is simultaneous in character, and the total model I will be block-recursive. By contrast, if a function whose explanatory variables are production and income is applied, the price formation part is recursive; and when the supply functions are also taken into account, the entire model II is also recursive.

In Part IV the estimates of the parameters are presented. The estimates of the recursive model II were obtained by employing the method of least squares, and the estimates of the simultaneous model I by the two-stage least squares method. The supply functions are the same for models I and II.

Price of feed was found to be the most important variable in the supply function for pork, the elasticity as given in Table 11.1 being -0.56. The elasticity of supply with respect to the producer price of pork (lagged 5 quarters) was only 0.20 , i.e., almost insignificant. The producer price of potatoes turned out to be negible factor for the supply of pork, judging by the low price elasticity. -0.07 .

The supply of beef seems to be determined mainly by feed supply in such a way that it is negatively correlated with the hay yield in the short run (elasticity - 0.88), but positively correlated in the long run, as is indicated by the positive sign of the regression coefficient of the trend variable $\mathrm{T}$ (see Table 14.5). The number of cows was the third important factor in the supply function for beef (elasticity 2.21). The other variables were rather insignificant, even though, e.g., the supply elasticities with respect to the lagged producer prices $(0.22$ and 0.12 for prices lagged one and two years respectively) were consistent in their signs.

The estimated net imports functions were rather poor regarding explanation, which implies that since net imports are partly predetermined in nature, they cannot be predicted satisfactorily by any functions. The TSLS functions

$11 \quad 8609-68$ 
Table 19.1. Price flexibilities of the quarterly demand functions as obtained by the TSLS and OLS methods.

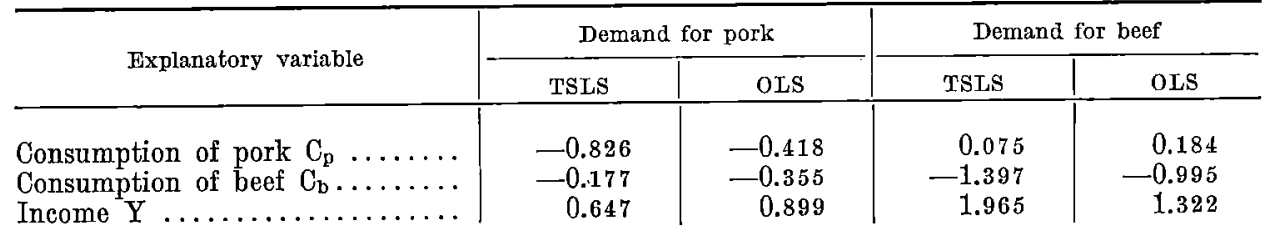

(16.4) and (16.5) yielded better explanations, $\mathrm{R}^{2}$ than did the OLS functions (15.1) and (15.2).

The coefficients of multiple determination were rather.low for the demand functions. The price flexibilities obtained were plausible, however, except that for the consumption of pork in the demand function for beef, since it was positive in sign and, thus, inconsistent with the a priori assumption that pork is a substitute for beef. The result was not, however, significant, since the regression coefficient was close to zero. The TSLS estimates of the demand functions seemed to be more plausible than those of the recursive model (see Table 19.1).

The price margin functions were consistent in respect to the signs of the regression coefficients. The most important variable in them was the wage level in commerce. Deflation of the prices and margins reduced the dependence of the price margin on the retail price. The TSLS functions (16.8) and (16.9) yielded higher $\mathrm{R}^{2}$ than the OLS functions (15.5) and (15.6). The coefficient of multiple determination for the price margin function for beef was low, and therefore it seems to be of little use in, for example, predictions.

The parameters were also estimated by applying semiannual data, but the results were about the same as in the case of the quarterly data.

The estimated functions were tested computing the matrix of the correlation coefficients of the residuals, in order to see whether the assumption of the non-correlation of the disturbances was valid. In this sense, the recursive model seemed to be better than the simultaneous model, since the residuals of the simultaneous model were correlated with each other more than the residuals of the recursive model. The test is, however, one for linear correlations only, and thus it is not complete.

Perhaps the best results in the entire study were obtained when the ordinary demand functions, which did not belong to the multi-equation models, were estimated. In these functions the per capita consumption was the dependent variable, the retail prices and disposable income being the explanatory variables. The elasticity of the demand for pork was -0.44 
with respect to the retail price of pork, 0.21 with respect to the retail price of beef and 0.24 with respect to income (Table 18.1). The demand for pork seems to be, in consequence, rather inelastic. The demand for beef was more elastic: -0.59 for the retail price of beef, about zero for the retail price of pork and 1.47 for income (Table 18.2).

The estimated models were also evaluated by applying them in the prediction of the producer price. Here, the results yielded by the simultaneous and recursive models were about the same. 


\section{REFERENCES}

Crom, Righard J. and Makt, Wilbur R.: A Dynamic Model of Simulated LivestockMeat Economy. Agricultural Economics Research, Vol. XVII, No. 3, July 1965.

DUESEABERRY, JaMes S. and Kuein, LAwrence R.: Introduction: The Research Strategy and its Application. In DUESENBERRY and others (eds.): The Brookings Quarterly Economic Model of the United States. Amsterdam 1965.

Durbin, J. and WAtson, G. S.: Testing for Serial Correlation in Least Squares Regression, pts. I and II, Biometrica 1950 and 1951.

Eisenpress, Harry and Greenstadt, Johr: The Estimation of Nonlinear Econometric Systems. Econometrica, Vol. 34, No. 4, Oetober 1966.

Fisher, Frankitn M.: Identification Problem in Econometrics. New York 1966.

Fox, Kard A.: The Analysis of Demand for Farm Products. U.S.Dept. of Agr., Technical Bulletin No. 1081. Washington 1953.

Friedman, JoAN and Foote, Richard J.: Computational Methods for Handling Systems of Simultaneous Equations. U.S.Dept. of Agr., Agriculture Handbook No. 94, November 1955.

Goldberger, Arthur S.: Econometric Theory. New York 1964.

Haikata, Eino: Maatalouden ominaissuhdanteet ja Cobweb-teoria (Summary: On the Specific Cycles of Agriculture and the Cobweb Theorem). Helsinki 1956.

Harlow, Arthur A.: A Recursive Model of the Hog Industry. Agricultural Economies Research, Vol. XIV, No. 1, January 1962.

Harcow, Arthur A.: Factors Affecting the Price and Supply of Hogs. U.S.Dept. of Agr., Technical Bulletin 1274. Washington 1962.

Hodor, JAmes P.: Demand and Price Analysis of the U.S. Soybean Market. University of Minnesota, Agricultural Experiment Station, Technical Bulletin 244. June 1963.

Johnston, J.: Econometric Methods. New York 1963.

KaARlehto, PaAvo: Sianlihan markkinoinnista Suomessa (Summary: A Study of the Pork Market in Finland). Maatalouden taloudellisen tutkimuslaitoksen julkaisuja No. 2. Helsinki 1959.

KaArlehto, PaAvo: Tulotason vaikutuksesta elintarvikemenoihin ja kulutusmääriin (Summary: Income Elasticity of Food Expenditure and Consumption). Maataloustieteellinen aikakauskirja, Vol. 33, No. 1.

Krein, Lawrence R.: An Introduction to Econometrics. Englewood Cliffs 1965.

Klein, Lawrence R.: A Textbook of Econometrics. Evanston, Ill. 1956.

Koopmans, TJalling C. and Hood, WM. C.: The Estimation of Simultaneous Linear Economic Relationships. In Hood, WM. C. and Koopmans, Tjalling C. (eds.): Studies in Econometric Method. Cowles Commission for Research in Economics, monograph No. 14, New York 1953. 
Langemeier, Larry and Thompson, Russed G.: Demand, Supply and Price Relationships for the Beef Sector Post-World War II Period. Journal of Farm Economics, Vol. 49, No. 1, Part I, February 1967.

Lovelu, Michate C.: Seasonal Adjustment of Economic Time Series and Multiple Regression Analysis. Journal of the American Statistical Association, Vol. 58, No. 304.

Matinvaud, E.: Statistical Methods of Econometrics. Studies in Mathematical and Managerial Economics, Vol. 6. Amsterdam 1966.

MARTin, James E.: Isolation of Lagged Economic Responses. Journal of Farm Economies, Vol. 49, No. I Part I, February 1967.

Nerlove, Marc: Distributed Lags and Estimation of Long-run Supply and Demand Elasticities: Theoretical Considerations. Journal of Farm Economics, Vol. 40, No. 2, May 1958.

Pöyнönen, PeNTri: Ekonometria. In WARIs and others (eds.): Yhteiskuntatieteiden Käsikirja T. Keuruu 1963.

Sardelin, Gostav: Naudanlihan kysynnästä (Summary: About Demand for Beef). Pellervo-Seuran markkinatutkimuslaitoksen 25-vuotisjulkaisu. Helsinki 1959.

Schultz, Henky: The Theory and Measurement of Demand. Chicago 1958.

Stanton, B. F.: Seasonal Demand for Beef, Pork, and Broilers. Agricultural Economics Research, Vol. XIII, No. 1, January 1961.

Stomeda, Samuli: The Changing Agricultural Price Laws. Economic Review No. 2, 1967, published by Kansallis-Osake-Pankki, Helsinki.

Their, H.: Economic Forecasts and Policy. Contributions to Economic Analysis XV. Amsterdam 1965.

Tintwer, Gerhard: Econometrics. New York 1952.

Waananen, Martin and KaArlehto, Paavo: Marketing Margins for Eggs in Finland. Washington Agricultural Experiment Stations, Technical Bulletin 45. April 1965.

Wrilrams, E. J.: Regression Analysis. New York 1959.

Wold, Herman: Forecasting by the Chain Principle. In Woud, Hermax O. A.: Econometric Model Building. Contributions to Economic Analysis XXXVI. Amsterdam 1964.

Wold, Herman and Jurézen, Lars: Demand Analysis. Uppsala 1952.

The Bulievin of Statistics. Central Statistical Office of Finland. Helsinki 1956-66.

MaAtaloustuotteiden hinnanmuodostuskomitean osammetintö II. Komiteanmietintö 1966: B 12. Helsinki 1966.

The Monthly Review of Agricultural Statistics. Board of Agriculture, Statistical Office. Helsinki 1956--66.

The Soctal Review, published by the Ministry of Social Affairs. Helsinli 1956-66. 


\title{
Appendix 1. Iist of variables and sources of data
}

\author{
List of variables \\ $\mathrm{X}_{\mathrm{p}} \quad=$ the quantity of pork produced, mill. kg (in demand functions kg per capita) \\ $\mathrm{X}_{\mathrm{pm}}=$ the quantity of pork marketed, mill. $\mathrm{kg}$ ( $\mathrm{kg}$ per capita) \\ $\mathrm{X}_{\mathrm{pl}} \cdot \quad=$ the quantity of pork consumed on farms, mill. $\mathrm{kg}$ \\ $\mathrm{X}_{\mathrm{b}} \quad=$ the quantity of beef and veal produced, mill. $\mathrm{kg}$ ( $\mathrm{kg}$ per capita) \\ $\mathrm{X}_{\mathrm{bm}}=$ the quantity of beef and veal marketed, mill. $\mathrm{kg}$ (kg per capita) \\ $\mathrm{X}_{\mathrm{b} f} \quad=$ the quantity of beef and veal consumed on farms, mill. $\mathrm{kg}$ \\ $\mathrm{C}_{\mathrm{p}} \quad=$ the quantity of pork consumed, $\mathrm{kg}$ per capita \\ $\mathrm{C}_{\mathrm{b}} \quad=$ the quantity of beef and veal consumed, $\mathrm{kg}$ per capita \\ $I m-\operatorname{Ex}_{\mathrm{p}}=$ the net imports of pork, kg per capita. \\ $\mathrm{Im}-\mathrm{Ex}_{\mathrm{b}}=$ the net imports of beef and veal, $\mathrm{kg}$ per capita \\ $\mathrm{P}_{\mathrm{pr}} \quad=$ the retail price of fresh pork, $\mathrm{mk}$ (marks) per $\mathrm{kg}$, the weighted average \\ of different cuts (for the weights, see Maataloustuotteiden hinnanmuodos- \\ tuskomitean osamietintö II, liite (appendix) VII a) \\ $\mathrm{P}_{\mathrm{br}} \quad=$ the retail price of fresh beef and veal, $\mathrm{mk}$ per $\mathrm{kg}$, computed as $\mathrm{P}_{\mathrm{pr}}$ \\ $\mathrm{P}_{\mathrm{pp}} \quad=$ the producer price of pork, mk per $\mathrm{kg}$ \\ $\mathrm{P}_{\mathrm{bp}} \quad=$ the producer price of beef and veal, $\mathrm{mk}$ per $\mathrm{kg}$ \\ $\mathrm{P}_{\mathrm{s}} \quad=$ the price of processed meat, the index of the arithmetic average of the \\ retail prices of different sorts of sausage given in Social Review \\ $\mathrm{M}_{\mathrm{p}} \quad=$ the price margin for pork $\left(=\mathrm{P}_{\mathrm{pr}}-\mathrm{P}_{\mathrm{pp}}\right), \mathrm{mk}$ per $\mathrm{kg}$ \\ $\mathrm{M}_{\mathrm{b}} \quad=$ the price margin for beef $\left(=\mathrm{P}_{\mathrm{br}}-\mathrm{P}_{\mathrm{bp}}\right)$, mk per $\mathrm{kg}$ \\ $\mathrm{Y} \quad=$ the disposable income; for the estimation, the wage index of all salary \\ and wage earners is used \\ $\mathrm{W}=$ the wage index in commerce \\ $\mathrm{T}=$ time $1,2,3, \ldots$, the first quarter or half-year of $1956=1$ \\ $\mathrm{Z}_{1} \quad=$ the producer price of pork, lagged 5 quarters, mk per $\mathrm{kg}$ \\ $\mathrm{Z}_{2} \quad=$ the producer price of potatoes, lagged 5 quarters, $\mathrm{p}$ (pennies) per $\mathrm{kg}$ \\ $Z_{3} \quad=$ the price of feed, lagged 5 quarters, $\mathrm{p}$ per $\mathrm{kg}$, the aritmetic average of \\ the producer prices of fodder oats and fodder barley and of the retail \\ price of wheat bran \\ $\mathrm{Z}_{4} \quad=$ the number of dairy cows, mill. pes., at the beginning of the corresponding \\ half-year \\ $\mathbf{Z}_{\mathbf{5}} \quad=$ the hay yield, 1000 mill. feed units, at the beginning of the crop year \\ (July-June) \\ $\mathrm{Z}_{6} \quad=$ the hay yield, lagged a year, 1000 mill. feed units \\ $\mathrm{Z}_{7} \quad=$ the producer price of beef and veal, lagged 4 quarters, mk per $\mathrm{kg}$ \\ $\mathbf{Z}_{8} \quad=$ the producer price of beef and veal, lagged 8 quarters, mk per $\mathrm{kg}$ \\ $\mathrm{Z}_{9} \quad=0.667 \mathrm{Z}_{7}+0.333 \mathrm{Z}_{8}$ \\ $\mathrm{Z}_{10}=$ the producer price index of agricultural products
}




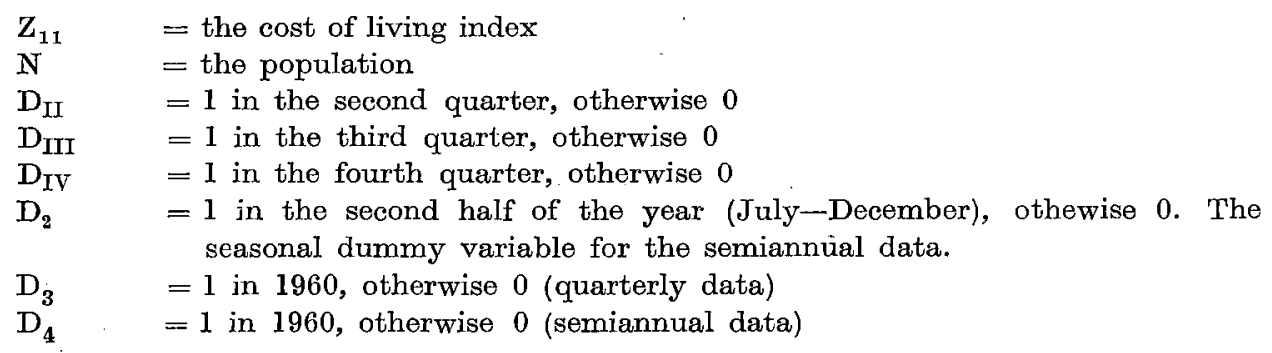

\section{Sources of data}

Production $\left(X_{p}, X_{p m}, X_{b}, X_{b m}\right)$, hay yield $\left(Z_{5}, Z_{6}\right)$ and the number of cows $\left(Z_{4}\right)$ : the Monthly Review of Agricultural Statistics, Board of Agriculture, Statistical Office. The quarterly data on the production consumed on the farms have been formed by assigning to each quarter half of the quantity of the corresponding half-year, which is given in the statistics available.

Imports and exports of pork and beef and veal $\left(\mathbf{I m}-\mathbf{E x}_{\mathbf{p}}, \mathbf{I m}-\mathbf{E x}_{\mathbf{b}}\right)$ : The Statistical Office, Board of Customs.

Producer prices of pork and beef and veal $\left(\mathrm{P}_{\mathrm{pp}}, \mathrm{P}_{\mathrm{pp}}\right)$ : the Marketing Research Institute of Pellervo Society and KK, Economic Research Office, the weighted average, the weights being 0.8 and 0.2 respectively.

The producer price of potatoes $\left(Z_{2}\right)$ and the price of feed $\left(Z_{3}\right)$, the arithmetic average of the producer prices of fodder oats and fodder barley and the retail price of wheat bran): the Marketing Research Institute of Pellervo Society.

The wage index of all salary and wage earners $(Y)$, the wage index in commerce $(W)$, the cost of living index $\left(Z_{11}\right)$ and the population $(N)$ : the Bulletin of Statistics, Central Statistical Office of Finland. Retail prices $\left(\mathrm{P}_{\mathrm{pr}}, \mathrm{P}_{\mathrm{br}}, \mathrm{P}_{\mathrm{s}}\right)$ : the Social Review, published by the Ministry of Social Affairs.

The producer price index of agricultural products $\left(Z_{100}\right)$ : the Agricultural Economics Research Institute, beginning from 1956, before that the Marketing Research Institute of Pellervo Society. 
Appendix II. Linear correlation coefficients of the variables included in each function

Supply of pork:

\begin{tabular}{|c|c|c|c|c|c|c|c|c|}
\hline & $x_{p}$ & $x_{p m}$ & $\mathrm{Z}_{1}$ & $\mathrm{Z}_{2}$ & $\mathrm{Z}_{3}$ & $T$ & $x_{p_{m t-5}}$ & $D_{3}$ \\
\hline$K_{p}$ & 1.0 & 0.821 & -0.169 & 0.044 & -0.197 & 0.321 & -0.088 & -0.343 \\
\hline $\mathrm{I}_{\mathrm{pn}}$ & - & 1.0 & -0.124 & -0.089 & 0.224 & 0.705 & 0.309 & -0.439 \\
\hline & - & - & 1.0 & 0.103 & -0.081 & -0.226 & -0.300 & -0.261 \\
\hline $\mathrm{Z}_{2}$ & 一 & - & - & 1.0 & 0.217 & -0.170 & -0.2 & -0.068 \\
\hline & - & - & $\cdots$ & - & 1.0 & 0.110 & -0.045 & 0.334 \\
\hline & - & - & - & - & 一 & 1.0 & 0.588 & -0.058 \\
\hline & 一 & - & - & - & 一 & - & 1.0 & -0.013 \\
\hline & - & - & - & - & 一 & - & & 1.0 \\
\hline
\end{tabular}

Supply of beef:

\begin{tabular}{|c|c|c|c|c|c|c|c|c|c|c|}
\hline & $x_{b}$ & $\mathrm{X}_{\mathrm{bm}}$ & $z_{4}$ & $\mathrm{Z}_{5}$ & $\mathrm{~T}$ & $Z_{s}$ & $\mathrm{z}_{7}$ & $Z_{8}$ & $z_{s}$ & $x_{b m t-5}$ \\
\hline & 1.0 & 0.991 & 0.728 & 0.126 & 0.859 & 0.540 & -0.151 & 0.136 & 0.071 & 0.824 \\
\hline $\mathrm{X}_{\mathrm{bm}}$ & - & 1.0 & 0.717 & 0.161 & 0.891 & 0.580 & -0.140 & 0.144 & -0.058 & 0.816 \\
\hline & - & - & 1.0 & 0.415 & 0.683 & 0.712 & 0.054 & 0.178 & 0.121 & 0.487 \\
\hline & -- & - & - & 1.0 & 0.509 & 0.532 & 0.118 & -0.454 & -0.093 & 0.257 \\
\hline & - & - & - & - & 1.0 & 0.669 & -0.104 & -0.104 & -0.132 & 0.846 \\
\hline & - & - & - & - & - & 1.0 & 0.450 & -0.001 & 0.383 & 0.263 \\
\hline & - & - & - & $\cdots$ & - & - & 1.0 & 0.126 & 0.091 & -0.434 \\
\hline & - & - & - & - & - & - & - & 1.0 & 0.532 & -0.097 \\
\hline & - & - & - & - & - & - & - & - & 1.0 & -0.412 \\
\hline $\mathrm{X}_{\mathrm{bmt-5}}$ & - & - & - & $\ldots$ & - & - & - & - & - & 1.0 \\
\hline
\end{tabular}

Net imports of pork:

\begin{tabular}{l|r|c|c|c}
\hline & $\mathrm{Im}-\mathrm{Ex}_{\mathrm{p}}$ & $\mathrm{P}_{\mathrm{p} p}$ & $\mathrm{x}_{\mathrm{p}}$ & $\mathrm{Y}$ \\
\hline $\mathrm{Im}-\mathrm{Ex}_{\mathrm{p}} \ldots$ & 1.0 & 0.234 & -0.319 & -0.130 \\
$\mathrm{P}_{\mathrm{pp}} \ldots \ldots \ldots$ & - & 1.0 & -0.244 & -0.102 \\
$\mathrm{X}_{\mathrm{p}} \ldots \ldots \ldots$ & - & - & 1.0 & 0.089 \\
$\mathrm{Y} \ldots \ldots \ldots$ & - & - & - & 1.0
\end{tabular}

Net imports of beef:

\begin{tabular}{l|c|c|c|c}
\hline & $\operatorname{Im}-\mathrm{Ex}_{\mathrm{b}}$ & $\mathrm{P}_{\mathrm{by}}$ & $\mathrm{X}_{\mathrm{b}}$ & $\mathrm{Y}$ \\
\cline { 2 - 5 } & & & & \\
$\operatorname{Im}-\mathrm{Ex}_{\mathrm{b}} \ldots$ & 1.0 & 0.433 & -0.342 & -0.034 \\
$\mathrm{P}_{\mathrm{b}} \ldots \ldots \ldots$ & - & 1.0 & -0.548 & -0.164 \\
$\mathrm{X}_{\mathrm{b}} \ldots \ldots \ldots$ & - & - & 1.0 & 0.851 \\
$\mathrm{Y} \ldots \ldots \ldots$ & - & - & - & 1.0
\end{tabular}


Appendix II. Continued

Demand functions (a):

\begin{tabular}{l|c|c|c|c|c}
\hline & $\mathrm{P}_{\mathrm{pr}}$ & $\mathrm{P}_{\mathrm{br}}$ & $\mathrm{C}_{\mathrm{p}}$ & $\mathrm{Cb}_{\mathrm{b}}$ & \multicolumn{1}{c}{$\mathrm{Y}$} \\
\cline { 2 - 4 } & 1.0 & 0.178 & 0.011 & 0.274 & 0.373 \\
$\mathrm{P}_{\mathrm{pr}} \ldots \ldots \ldots$ & - & 1.0 & 0.072 & -0.475 & -0.221 \\
$\mathrm{P}_{\mathrm{br}} \ldots \ldots \ldots$ & - & - & 1.0 & 0.285 & 0.055 \\
$\mathrm{C}_{\mathrm{p}} \ldots \ldots \ldots$ & - & - & - & 1.0 & 0.882 \\
$\mathrm{G}_{\mathrm{b}} \ldots \ldots \ldots$ & - & - & - & - & 1.0
\end{tabular}

Demand functions (b):

\begin{tabular}{l|r|r|r|r|r|r|r}
\hline & $\mathrm{P}_{\mathrm{pr}}$ & $\mathrm{P}_{\mathrm{br}}$ & $\mathrm{X}_{\mathrm{p}}$ & $\mathrm{X}_{\mathrm{b}}$ & $\mathrm{Im}-\mathrm{Exp}$ & $\mathrm{Im}-\mathrm{Ex}_{\mathrm{b}}$ & $\mathrm{X}$ \\
\cline { 2 - 4 } & 1.0 & 0.178 & -0.143 & 0.280 & 0.534 & -0.059 & 0.373 \\
$\mathrm{P}_{\mathrm{pr}} \ldots \ldots \ldots$ & - & 1.0 & 0.019 & -0.556 & 0.169 & 0.334 & -0.221 \\
$\mathrm{P}_{\mathrm{br}} \ldots \ldots \ldots$ & - & - & 1.0 & 0.344 & -0.319 & -0.169 & 0.089 \\
$\mathrm{X}_{\mathrm{p}} \ldots \ldots \ldots$ & - & - & - & 1.0 & -0.155 & -0.342 & 0.851 \\
$\mathrm{X}_{\mathrm{b}} \ldots \ldots \ldots$ & - & - & - & - & 1.0 & 0.118 & -0.130 \\
$\mathrm{I}_{\mathrm{m}}-\mathrm{Ex}_{\mathrm{p}} \ldots$ & - & - & - & - & - & 1.0 & -0.034 \\
$\mathrm{Im}-\mathrm{Ex}_{\mathrm{b}} \ldots$ & - & - & - & - & - & - & 1.0
\end{tabular}

Price margin for pork:

\begin{tabular}{l|c|c|c|c}
\hline & $\mathrm{M}_{\mathrm{p}}$ & $\mathrm{P}_{\mathrm{pr}}$ & $\mathrm{Im}-\mathrm{Ex}_{\mathrm{p}}$ & $\mathrm{W}$ \\
\hline & & & & \\
$\mathrm{M}_{\mathrm{p}} \ldots \ldots \ldots \ldots$ & 1.0 & 0.348 & -0.148 & -0.271 \\
$\mathrm{P}_{\mathrm{pr}} \ldots \ldots \ldots \ldots$ & - & 1.0 & 0.534 & $\mathbf{0 . 3 6 9}$ \\
$\mathrm{Im}-\mathrm{Ex}_{\mathrm{p}} \ldots \ldots$ & - & - & 1.0 & -0.163 \\
$\mathrm{~W} \ldots \ldots \ldots$ & - & - & - & 1.0
\end{tabular}

Price margin for beef:

\begin{tabular}{l|c|c|c|c}
\hline & $\mathrm{M}_{\mathrm{b}}$ & $\mathrm{P}_{\mathrm{br}}$ & $\mathrm{Im}-\mathrm{Ex}_{\mathrm{b}}$ & $\mathrm{W}$ \\
\cline { 2 - 5 } $\mathrm{M}_{\mathrm{b}} \ldots \ldots \ldots \ldots$ & 1.0 & 0.068 & -0.263 & -0.015 \\
$\mathrm{P}_{\mathrm{br}} \ldots \ldots \ldots \ldots$ & $-\mathrm{Ex}_{\mathrm{b}} \ldots \ldots$ & - & -0.334 & -0.249 \\
$\mathrm{Im} \ldots \ldots$ & - & - & 1.0 & -0.308 \\
$\mathrm{~W} \ldots \ldots$ & - & - & 1.0
\end{tabular}


A ppendix III. Observed values of the variables used in the analysis. For the units of measurement, see Appendix I

\begin{tabular}{|c|c|c|c|c|c|c|c|c|c|c|}
\hline & Year Quarter & $x_{p}$ & $\mathrm{x}_{\mathrm{pm}}$ & $\mathrm{x}_{\mathrm{pf}}$ & $x_{b}$ & $x_{b m}$ & $\mathrm{x}_{\mathrm{bf}}$ & $\mathrm{C}_{\mathbf{p}}$ & $\mathrm{C}_{\mathbf{b}}$ & $I m-E x_{p}$ \\
\hline \multirow[t]{4}{*}{1956} & $I \ldots \ldots \ldots$ & 12.31 & 8.86 & 3.45 & 14.94 & 13.74 & 1.20 & 2.92 & 3.50 & 0.040 \\
\hline & II $\ldots \ldots \ldots$ & 13.12 & 9.67 & 3.45 & 16.20 & 15.00 & 1.20 & 3.21 & 3.79 & 0.143 \\
\hline & III $\ldots \ldots \ldots$ & 15.63 & 10.13 & 5.50 & 17.93 & 15.18 & 2.75 & 3.83 & 4.18 & 0.182 \\
\hline & IV $\ldots \ldots \ldots$ & 17.94 & 12.44 & 5.50 & 18.48 & 15.73 & 2.75 & 4.17 & 4.39 & 0.000 \\
\hline \multirow[t]{4}{*}{1957} & $\ldots \ldots \ldots$ & 13.87 & 10.57 & 3.30 & 16.19 & 14.84 & 1.35 & 3.21 & 3.75 & 0.000 \\
\hline & II $\ldots \ldots \ldots$ & 13.96 & 10.66 & 3.30 & 16.68 & 15.33 & 1.35 & 3.22 & 3.85 & 0.000 \\
\hline & III $\ldots \ldots \ldots$ & 16.34 & 10.39 & 5.95 & 15.62 & 13.52 & 2.10 & 3.76 & 3.60 & 0.000 \\
\hline & IV $\ldots \ldots \ldots$ & 20.12 & 14.17 & 5.95 & 16.60 & 14.59 & 2.10 & 4.46 & 3.82 & -0.175 \\
\hline \multirow[t]{4}{*}{1958} & I & 15.90 & 12.20 & 3.70 & 15.33 & 13.83 & 1.50 & 3.56 & 3.52 & -0.087 \\
\hline & II $\ldots \ldots$ & 15.54 & 11.84 & 3.70 & 14.87 & 13.37 & 1.50 & 3.29 & 3.40 & -0.268 \\
\hline & III $\ldots \ldots \ldots$ & 16.81 & 11.21 & 5.60 & 16.49 & 14.79 & 1.70 & 3.82 & 3.76 & -0.023 \\
\hline & IV $\ldots \ldots \ldots$ & 19.00 & 13.40 & 5.60 & 17.09 & 15.39 & 1.70 & 4.34 & 3.90 & 0.000 \\
\hline \multirow[t]{4}{*}{1959} & $\ldots \ldots \ldots$ & 13.90 & 10.95 & 2.95 & 15.94 & 14.89 & 1.05 & 3.17 & 3.63 & 0.000 \\
\hline & II & 14.04 & 11.09 & 2.95 & 17.05 & 16.00 & 1.05 & 2.98 & 3.88 & -0.211 \\
\hline & III $\ldots .$. & 16.14 & 11.54 & 4.60 & 18.81 & 17.31 & 1.50 & 3.66 & 4.27 & 0.002 \\
\hline & IV $\ldots . .$. & 18.04 & 13.44 & 4.60 & 19.85 & 18.35 & 1.50 & 4.03 & 4.50 & -0.054 \\
\hline \multirow[t]{4}{*}{1960} & $I \ldots \ldots$ & 12.23 & 9.73 & 2.50 & 19.15 & 17.85 & 1.30 & 3.02 & 4.33 & 0.251 \\
\hline & II $\ldots \ldots$ & 11.40 & 8.90 & 2.50 & 17.77 & 16.47 & 1.30 & 2.85 & 4.01 & 0.275 \\
\hline & III $\ldots \ldots$ & 14.92 & 9.82 & 5.10 & 17.29 & 15.79 & 1.50 & 3.65 & 3.09 & 0.291 \\
\hline & IV $\ldots .$. & 15.84 & 10.74 & 5.10 & 17.41 & 15.91 & 1.50 & 3.90 & 3.97 & 0.337 \\
\hline \multirow[t]{4}{*}{1961} & $\mathrm{I} \ldots \ldots$ & 12.73 & 10.68 & 2.05 & 15.04 & 13.99 & 1.05 & 3.06 & 4.33 & 0.196 \\
\hline & II $\ldots \ldots$ & 12.83 & 10.78 & 2.05 & 16.47 & 15.42 & 1.05 & 2.85 & 4.30 & -0.025 \\
\hline & III $\ldots \ldots \ldots$ & 16.85 & 12.30 & 4.55 & 17.53 & 15.83 & 1.70 & 3.80 & 4.38 & 0.029 \\
\hline & IV $\ldots \ldots \ldots$ & 18.87 & 14.32 & 4.55 & 19.28 & 17.58 & 1.70 & 4.21 & 4.54 & -0.002 \\
\hline \multirow[t]{4}{*}{1962} & $\mathrm{I}$ & 15.47 & 12.57 & 2.90 & 19.53 & 18.38 & 1.15 & 3.45 & 4.35 & 0.004 \\
\hline & II & 15.43 & 12.53 & 2.90 & 18.95 & 17.80 & 1.15 & 3.43 & 4.24 & 0.004 \\
\hline & III $\ldots$ & 18.19 & 13.89 & 4.30 & 19.94 & 18.24 & 1.70 & 3.73 & 4.65 & -0.299 \\
\hline & IV $\ldots \ldots \ldots$ & 20.28 & 15.98 & 4.30 & 22.17 & 20.47 & 1.70 & 4.59 & 4.90 & 0.106 \\
\hline \multirow[t]{4}{*}{1963} & $\mathrm{I}$ & 15.45 & 13.80 & 1.65 & 21.25 & 20.00 & 1.25 & 3.28 & 4.69 & -0.128 \\
\hline & II $\ldots \ldots \ldots$ & 14.95 & 13.30 & 1.65 & 20.45 & 19.20 & 1.25 & 3.10 & 4.50 & -0.196 \\
\hline & III $\ldots \ldots \ldots$ & 17.00 & 12.90 & 4.10 & 23.05 & 20.90 & 2.15 & 3.75 & 5.07 & 0.009 \\
\hline & IV $\ldots \ldots \ldots$ & 19.30 & 15.20 & 4.10 & 23.75 & 21.60 & 2.15 & 4.37 & 5.18 & 0.138 \\
\hline \multirow[t]{4}{*}{1964} & $\mathrm{I}$ & 14.45 & 12.90 & 1.55 & 23.45 & 22.10 & 1.35 & 3.16 & 5.12 & 0.002 \\
\hline & II & 15.15 & 13.60 & 1.55 & 22.95 & 21.60 & 1.35 & 3.22 & 5.01 & -0.087 \\
\hline & III . . & 17.60 & 13.90 & 3.70 & 25.30 & 22.90 & 2.40 & 3.83 & 5.51 & -0.002 \\
\hline & IV $\ldots \ldots \ldots$ & 19.60 & 15.90 & 3.70 & 26.30 & 23.90 & 2.40 & 4.14 & 5.79 & -0.122 \\
\hline \multirow[t]{4}{*}{1965} & $I \ldots \ldots \ldots$ & 15.10 & 13.70 & 1.40 & 24.40 & 23.00 & 1.40 & 3.13 & 5.12 & -0.148 \\
\hline & II $\ldots \ldots \ldots$ & 15.50 & 14.10 & 1.40 & 23.70 & 22.30 & 1.40 & 3.44 & 5.02 & 0.074 \\
\hline & III $\ldots \ldots \ldots$ & 17.95 & 14.40 & 3.55 & 22.40 & 20.70 & 1.70 & 3.82 & 4.95 & -0.067 \\
\hline & IV $\ldots \ldots \ldots$ & 20.15 & 16.60 & 3.55 & 24.10 & 22.40 & 1.70 & 4.22 & 5.28 & -0.143 \\
\hline
\end{tabular}


Appendix III (continued). Observed values of the variables used in the analysis

\begin{tabular}{|c|c|c|c|c|c|c|c|c|c|c|c|c|}
\hline & Tear Qu & $\left|\operatorname{Im}-\mathbf{E x}_{\mathrm{b}}\right|$ & $P_{p r}$ & $\mathbf{P}_{\mathrm{br}}$ & $P_{p p}$ & $P_{b p}$ & $\mathrm{P}_{\mathrm{s}}$ & $\mathrm{M}_{\mathrm{p}}$ & $\mathbf{M}_{\mathrm{b}}$ & $\mathrm{Y}$ & $w$ & $\mathbf{T}$ \\
\hline \multirow[t]{4}{*}{1956} & I & 0 & 3.06 & 2.55 & 2.33 & 1.95 & 1.00 & 0.73 & 0.60 & 0.88 & 0.90 & \\
\hline & $\mathrm{II}^{\prime}$. & 0 & 3.01 & 2.65 & 2.19 & 2.15 & 1.00 & 0.82 & 0.40 & 0.96 & .98 & \\
\hline & III: . & 0 & 3.09 & 2.77 & 2.25 & 2.10 & 1.00 & 0.84 & 0.67 & 0.99 & 0.99 & \\
\hline & IV . . & 0 & 3.21 & 2.70 & 2.44 & 2.02 & 1.21 & 0.77 & 0.68 & 0.99 & 0.99 & \\
\hline \multirow[t]{4}{*}{1957} & $\mathrm{I}$ & 0 & 3.37 & 2.80 & 2.65 & 2.31 & 1.32 & 0.72 & 0.49 & 9 & 0.99 & \\
\hline & II & 0 & 3.31 & 2.95 & 2.48 & 2.49 & 1.33 & 0.83 & 0.46 & 9 & 0.99 & \\
\hline & III & 0 & 3.22 & 3.05 & 2.26 & 2.48 & 1.36 & 0.96 & 0.57 & .01 & 1.00 & \\
\hline & IV,. & 0 & 3.09 & 3.01 & 2.21 . & 2.45 & 1.43 & 0.88 & 0.56 & 1.01 & 1.02 & \\
\hline \multirow[t]{4}{*}{1958} & $\mathrm{I}^{3}$ & 0 & 2.94 & 3.06 & 2.06 & 2.30 & 1.44 & 0.88 & 0.76 & 1.01 & 1.03 & \\
\hline & $\mathrm{II}:$ & 0 & 2.86 & 3.0 & 2.07 & 2.29 & 1.44 & 0.79 & & & & 10 \\
\hline & III & 0 & 3.22 & 3.12 & 2.49 & 2.22 & 1.45 & 0.73 & & & & 11 \\
\hline & IV & 0 & 3.36 & 2.99 & 2.50 & 2.09 & 1.45 & 0.86 & 0.90 & 1.07 & 1.07 & 12 \\
\hline \multirow[t]{4}{*}{1959} & I & 0 & 3.21 & 2.85 . & 2.34 & 2.11 & 1.45 & .87 & & & & 3 \\
\hline & II. & 0 & 3.12 & 2.73 & 2.28 & 2.15 & 1.45 & 84 & & & & 14 \\
\hline & III . . & 0 & 3.28 & 2.74 & 2.47 & 2.02 & 1.45 & 81 & & & 10 & 1 \\
\hline & IV $\ldots$ & 0 & 3.45 & 2.55 & 2.66 & 1.92 & 1.45 & 0.81 & 0.63 & 1.11 & 1.10 & 1 \\
\hline \multirow[t]{4}{*}{1960} & $\mathrm{I}$ & 0 & 3.72 & 2.62 & 2.95 & 2.07 & 1.45 & 1.77 & & 4 & & 1 \\
\hline & II: & 0 & 3.64 & 2.96 & 2.75 & 2.60 & 1.53 & 0.89 & & & 5 & 1 \\
\hline & III . & 0.0 & $3.70^{\circ}$ & 3.27 & 2.74 & 2.76 & 1.62 & 0.96 & & 7 & 15 & 1 \\
\hline & IV ........... & 0.056 & 3.98 & 3.40 & 3.01 & 2.83 & 1.69 & 0.97 & 0.57 & 1.18 & 1.16 & 2 \\
\hline \multirow[t]{4}{*}{1961} & $\ldots \ldots \ldots$ & & 3.73 & 3.3 & 2.72 & 2.86 & 1.7 & 1.01 & & & & 2 \\
\hline & II & 0.6 & 3.46 & 3.3 & 2.53 & 2.80 & 1.70 & 0.93 & 0.55 & 1.5 & 1.21 & 2 \\
\hline & III $\ldots$ & 0.454 & 3.57 & 3.45 & 2.57 & 2.81 & 1.70 & 1.00 & 0.64 & 1.26 & 1.23 & 2 \\
\hline & IV $\ldots . . . .$. & 0.237 & 3.74 & 3.28 & 2.77 & 2.64 & 1.63 & 0.97 & 0.64 & 1.28 & 1.23 & 2 \\
\hline \multirow[t]{4}{*}{1962} & $\mathrm{I}$ & & 3.84 & 3.3 & 2.86 & 2.7 & 1.6 & & & & & \\
\hline & II & 0.024 & 3.69 & 3.28 & 2.58 & 2.76 & 1.63 & 1.09 & 0.52 & 3 & 1.29 & 2 \\
\hline & III . . & & 3.68 & 3.29 & 2.56 & 2.69 & 1.63 & 1.12 & 0.60 & 33 & 1.30 & 2 \\
\hline & IV $\ldots \ldots \ldots$ & 0.000 & 3.87 & 3.24 & .2 .80 & 2.49 & 1.63 & 1.07 & 0.75 & 1.35 & 1.31 & 2 \\
\hline \multirow[t]{4}{*}{1963} & $I$ & & 3.9 & 3.2 & 2.8 & 2. & 1. & 1.16 & & 1. & & 2 \\
\hline & II & 0.000 & 4.03 & 3.40 & 2.81 & 2.82 & 1.63 & 1.22 & 58 & 1.45 & 1.45 & 30 \\
\hline & III, & 0.000 & 4.10 & 3.50 & 2.88 & 2.70 & 1.72 & 1.22 & 0.80 & 1.48 & 1.45 & 3. \\
\hline & IV $\ldots \ldots \ldots$ & -0.031 & 4.37 & 3.39 & 3.10 & 2.47 & 1.89 & 1.27 & 0.92 & 1.49 & 1.45 & \\
\hline \multirow[t]{4}{*}{1964} & $\mathrm{I}$ & -0.009 & 4.4 & & & & & & & & & 33 \\
\hline & II & 0.000 & 4.35 & 3.4 & 2.93 & 2.7 & 1.99 & 1.42 & 0 & 1.65 & 1.62 & 3 \\
\hline & III.$\therefore \ldots$ & 0.000 & 4.36 & 3.5 & 2.95 & 2.64 & 1.99 & 1.41 & & $1 . t$ & 1.63 & 3 \\
\hline & IV $\ldots \ldots \ldots$ & -0.017 & 4.48 & 3.29 & 3.11 & 2.39 & 1.99 & 1.37 & 0.90 & 1.69 & 1.69 & 36 \\
\hline \multirow[t]{4}{*}{1965} & $\mathrm{I}$ & -0.183 & 4.64 & 3.4 & 3.24 & 2.7 & 1.99 & 1.40 & 0. & 1.7 & $1 . t$ & 37 \\
\hline & II . . .... & -0.121 & 4.84 & 4.0 & 3.39 & 3.21 & 2.03 & 1.45 & 0.79 & 1.79 & 1.74 & 38 \\
\hline & III $\ldots \ldots$. & 0.100 & 4.90 & 4.34 & 3.29 & 3.33 & 2.12 & 1.61 & 1.01 & 1.80 & 1.74 & 39 \\
\hline & IV $\ldots \ldots \ldots \ldots$ & 0.067 & 5.02 & 4.35 & 3.42 & 3.34 & 2.12 & 1.60 & 1.01 & 1.79 & 1.74 & 40 \\
\hline
\end{tabular}


Appendix III (continued). Observed values of the variables used in the analysis

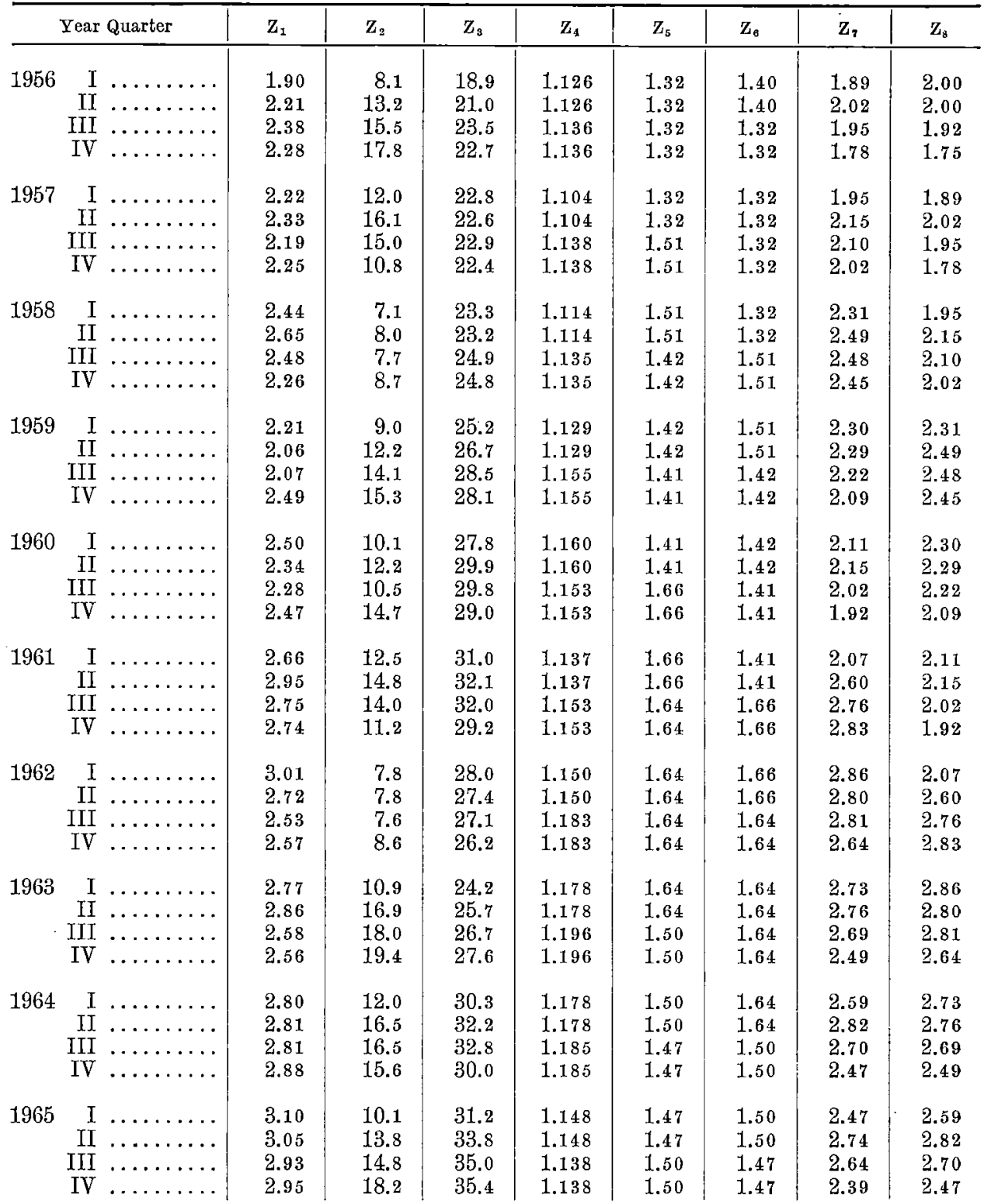


A p pendix IV. Deflators and population, quarterly values 1954-65

\begin{tabular}{|c|c|c|c|c|c|c|c|c|c|c|c|c|}
\hline \multirow{2}{*}{ Year } & \multicolumn{4}{|c|}{ Cost of living index } & \multicolumn{4}{|c|}{$\begin{array}{l}\text { Producer price index } \\
\text { of agricultural products }\end{array}$} & \multicolumn{4}{|c|}{$\begin{array}{l}\text { Population } \\
\text { mill. }\end{array}$} \\
\hline & I & II & III & IV & $\mathrm{I}$ & II & III & I V & $\mathrm{I}$ & II & III & IV \\
\hline 1954 & - & $\ldots$ & 一 & $\ldots$ & 79 & 79 & 78 & 79 & - & 一 & - & \\
\hline 1955 & & - & - & 一 & 83 & 88 & 88 & 92 & $\ldots$ & - & 一 & $\longrightarrow$ \\
\hline 1956 & 106 & 109 & 112 & 116 & 99 & 100 & 100 & 102 & 4.27 & 4.28 & 4.29 & 4.30 \\
\hline 1957 & 120 & 122 & 125 & 127 & 102 & 100 & 99 & 102 & 4.32 & 4.33 & 4.34 & 4.34 \\
\hline 1958 & 130 & 132 & 132 & 133 & 102 & 105 & 107 & 109 & 4.36 & 4.37 & 4.38 & 4.38 \\
\hline 1959 & 133 & 133 & 133 & 136 & 108 & 107 & 109 & 113 & 4.39 & 4.40 & 4.41 & 4.41 \\
\hline 1960 . & 136 & 138 & 138 & 140 & 115 & 116 & 115 & 119 & 4.42 & 4.43 & 4.44 & 4.45 \\
\hline $1961 \ldots$ & 140 & 140 & 140 & 142 & 117 & 114 & 114 & 117 & 4.45 & 4.46 & 4.47 & 4.48 \\
\hline $1962 \ldots$ & 143 & 146 & 148 & 150 & 119 & 117 & 117 & 118 & 4.49 & 4.50 & 4.51 & 4.52 \\
\hline 1963. & 151 & 153 & 155 & 158 & 121 & 122 & 122 & 125 & 4.53 & 2.54 & 4.55 & 4.56 \\
\hline 1964 . & 165 & 170 & 171 & 173 & 126 & 131 & 133 & 140 & 4.57 & 4.58 & 4.59 & 4.60 \\
\hline 1965. & 175 & 177 & 179 & 180 & 145 & 149 & 146 & 147 & 4.60 & 4.61 & 4.62 & 4.62 \\
\hline
\end{tabular}


